\title{
Design para a experiência e as tecnologias de informação e comunicação [Dissertação de Mestrado]
}

Nilton Nardelli

Orientação: Prof. Assoc. Dr. Marcelo Tamontano 



Dissertação apresentada ao
ргоgrama de Pós-Graduação em
Arquitetura e Urbanismo, Escola de
Engenharia de São Carlos,
Universidade de São Paulo, como
parte dos requisitos para a
obtenção do Título de Mestre em
Агquitetura.

\title{
DESIGN PARA A EXPERIÊNCIA
}

e o uso das tecnologias de informação e comunicação

\author{
[Dissertação de Mestrado] \\ Nilton César Nardelli \\ Orientação: Prof. Assoc. Dr. Marcelo Tramontano
}

São Carlos

2007 
AUTORIZO A REPRODUÇÃO E DIVULGAÇÃO TOTAL OU PARCIAL DESTE TRABALHO, POR QUALQÜER MEIO CONVENCIONAL OU ELETRÔNICO, PARA FINS DE ESTUDO E PESQUISA, DESDE QUE CITADA A FONTE.

Ficha catalográfica preparada pela Seção de Tratamento da Informação do Serviço de Biblioteca - EESC/USP

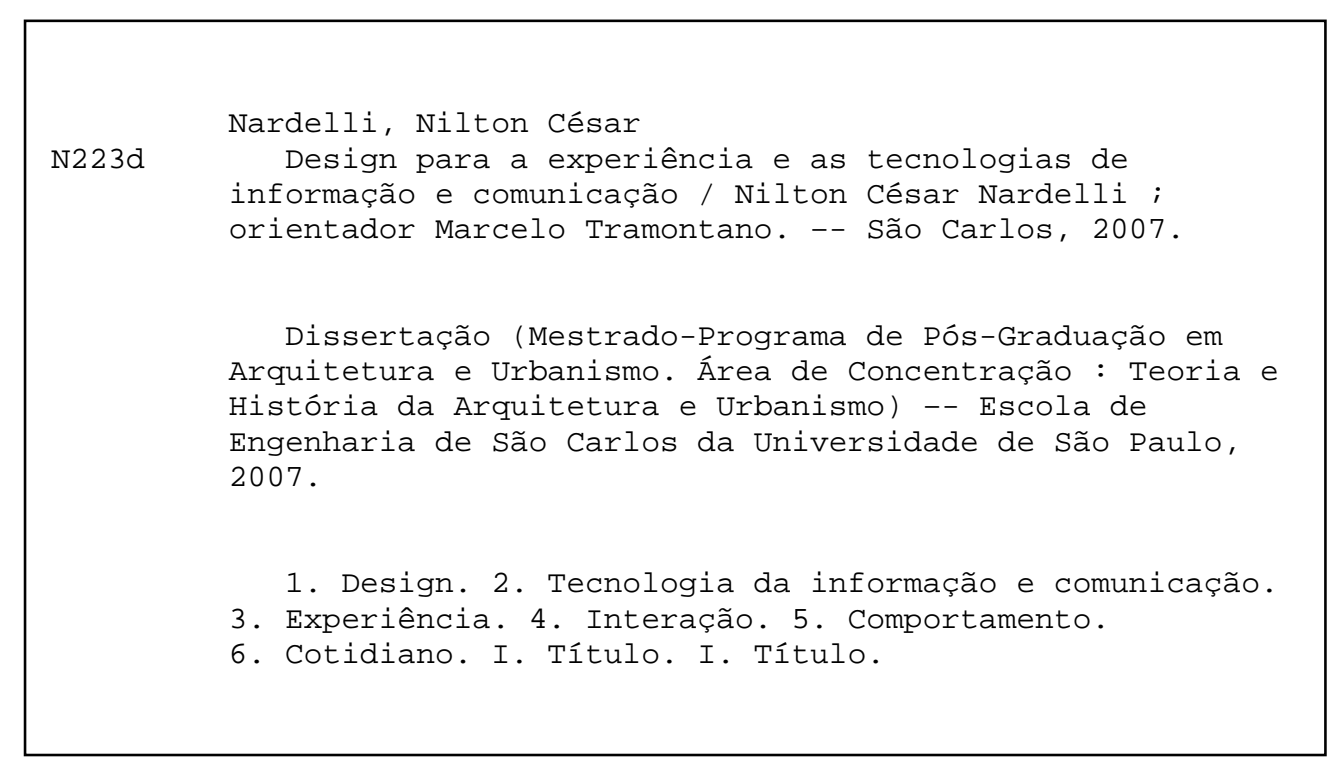




\section{FOLHA DE JULGAMENTO}

\section{Candidato: Arquiteto e Urbanista NILTON CÉSAR NARDELLI}

Disseftação defendida e julgada em 16/10/2007 perante a Comissão Julgadora:

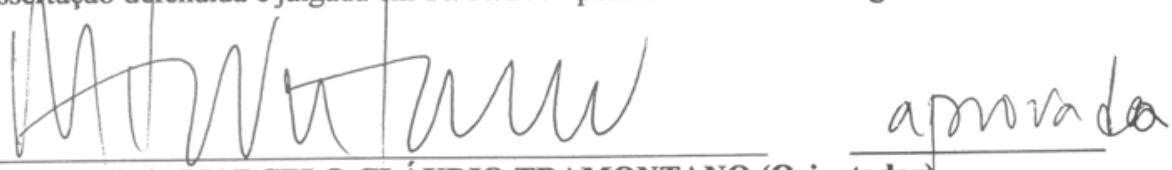

Prof. Associado MARCELO CLÁUDIO TRAMONTANO (Orientador)

(Escola de Engenharia dA São Carlos/USP)

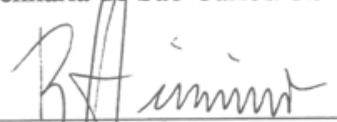

APROVADO

Prof. Dr. RODRIGOJJOSÉ FIRMINO

(Pontificia Universidade Católica do Paraná/PUCPR)

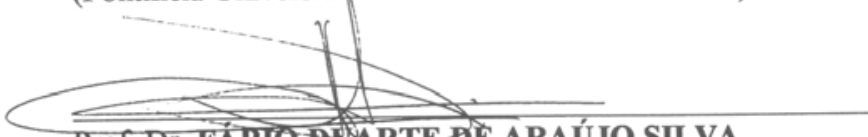

APROVADDO

Prof. DI. FẢBIO DUARTE DE ARAÚJO SILVA

(Pontificia Universidade Católica do Paraná/PUCPR)

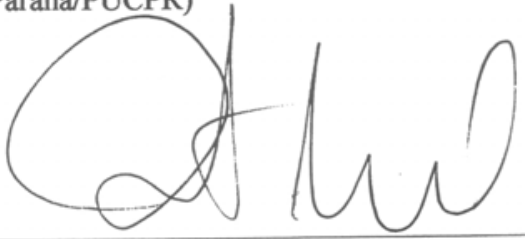

Prof. Associado RENATO LUIZ SOBRAL ANELLI

Coordenador do Programa de Pós-Graduação em Arquitetura e Urbanismo

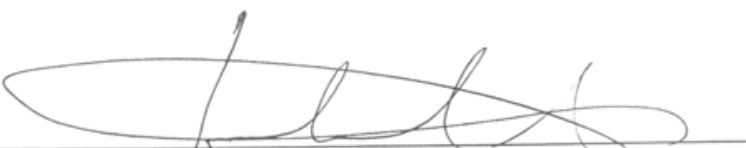

Prof. Associado GERALDO ROBERTO MARTINS DA COSTA

Presidente da Comissão da Pós-Graduação da EESC 

Dedicatória

Aos meus pais Luiz Nardelli e Anizia Nardelli pelo apoio incondicional a todas as escolhas que eu minha irmã, Lili, fizemos ao longo de
nossas vidas. 



\section{Agradecimentos}

Ao meu orientador, Prof. Assoc. Dr. Marcelo Tramontano, cujo papel de acompanhamento ao longo de todo o período de pesquisa foi bem além da função de um orientador.

Aos professores do Departamento de Arquitetura e Urbanismo da Escola de Engenharia de São Carlos que acompanharam e colaboraram refinando a discussão ргоposta por este trabalho.

Aos colegas pesquisadores do Nomads.usp que contribuíram diretamente a esta pesquisa por meio de seus trabalhos e críticas, Profa. Anja Pratschke, Carolina Abrahão Alves, Clarissa Ribeiro, Cynthia Nojimoto, Denise Tahan Melo, Fábio Abreu, Gabriela Сarneiro, Guto Requena, Mayara Dias, Renata la Rocca, Rodrigo Peronti, Tânia Bulhões, Tatiana Sakurai, Profa. Varlete Benevente.

Aos Amigos sempre presentes, Aleteia Pedroso, Camila Pompolo, Daniel Masiero, Fernanda Marinelli, Graziela Nivoloni, José Ricardo Rosolen, Juliana Zancul, Maria Cecília de Almeida, Mônica Viana, Мarina Вarros, Rogério, Rubia Michelato.

Aos funcionários do SAP/ EESC/ USP, Alessandro, Evandro, Fátima, João, José Renato Dibo, Paulo Ceneviva, Sérgio e Marcelo Celestini, Oswaldo, Zanardi.

Ao Conselho Nacional de Desenvolvimento Científico e Tecnológico - CNPq, pelo financiamento dessa pesquisa. 

"A imobilidade das coisas que nos cercam talvez lhes seja imposta por nossa certeza de que essas coisas são elas mesmas e não outras, pela imobilidade de nosso pensamento регante elas".

(Marcel Proust) 



\section{Resumo}

Esta pesquisa tem como tema de estudo as relações interpessoais no cotidiano e 0 uso das tecnologias de informação e comunicação no fomento de experiências. Seu objetivo é desenvolver um quadro teórico em torno de uma área do design intitulada de design рага а experiência. Рara tal, a metodologia da pesquisa fundamenta-se na seleção de propostas de design que exploram questões ligadas ao comportamento no espaço doméstico e às tecnologias de informação e comunicação. Em seguida é realizada uma análise qualitativa dessas propostas a partir de alguns critérios também desenvolvidos pela pesquisa.

Palavras-chave: design para a experiência, tecnologias de informação e comunicação, comportamento, espaço doméstico.

\section{Abstract}

This research studies the daily interрersonal relations and the information and communication technologies usage to stimulate experiences. The goal is to develop the theoretical references around a design агеa identified as experience design. In огder to achieve that the research methodology is based on the analysis of some design ргоposals, which explores issues related to the people's behavior inside the domestic environment and to the information and communication technologies. These proposals are investigated according to principles also developed during the research.

Key-words: Experience design, information and communication technologies, human behavior, domestic environments. 



\section{SUMÁRIO}

INTRODUÇÃO.

\section{CAPÍTULO 1: Design, comportamento e tecnologia}

1.1. Design: conceito.........................................................................................................................

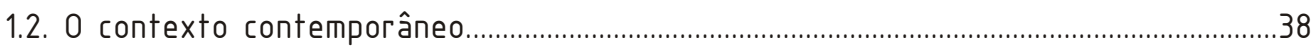

1.3. Aspectos da família contemporânea..............................................................................41

1.4. A inserção das mídias no espaço doméstico e o comportamento..................................50

1.5. Um pouco de cinema, fiç̧ão e futurismo......................................................................

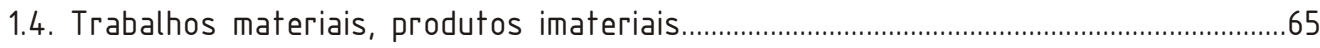

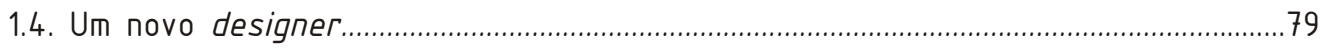

\section{CAPÍTULO 2: Design para a Experiência.}

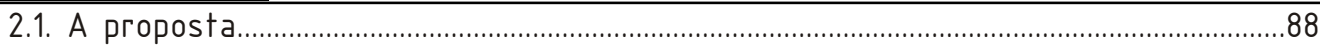

2.2. Diálogos com a pós-modernidade: A origem de alguns conceitos.................................93

2.3. 0 papel do indivíduo, do designer e do objeto dentro do sistema que leva a experiência................................................................................102

2.4. 0 uso das mídias digitais no fomento de experiências..................................................112

2.5. Notas рага uma leitura dos ргodutos do design рага а experiência.........................122

2.5.1. Comunicação, mensagem e informação........................................................................123

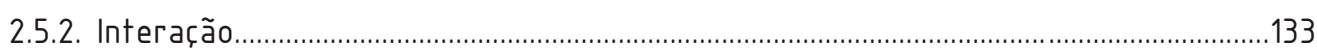

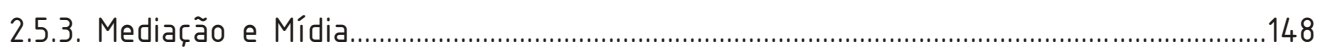

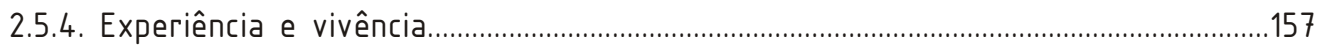




\section{CAPÍTULO 3: Leitura dos produtos selecionados}

3.1. Critérios de Seleção e de análise dos produtos...........................................................171

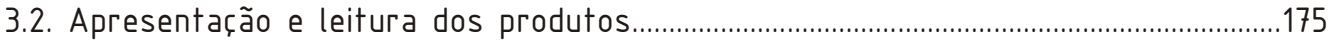

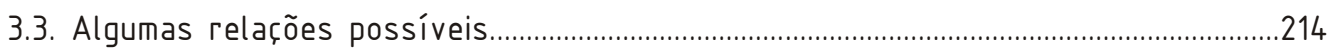

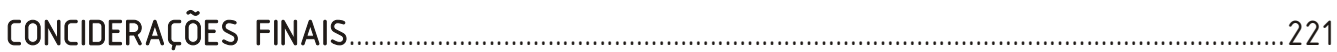

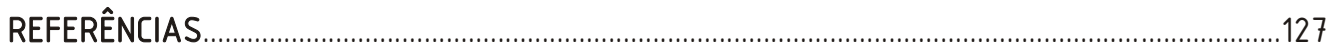

LISTA DE FIGURAS 
INTRODUÇÃO 

Uma das convições enraizadas no relato bíblico diz existirem três reinos no universo: o das coisas naturais, como as pedras, os vegetais e os animais; o reino dos homens e finalmente, o reino dos engenhos рог ele fabricados. 0 que se aprende no Gênesis é que tais domínios são estanques e profundamente diversos na sua substância. Segundo Bennaton [1984] desta teoria originam-se entendimentos que marcam profundamente forma de entendermos o mundo. A partir destes postulados, depreende-se, рог exemplo, que não há possibilidade de sobrepor os dois primeiros reinos, porque o homem, graças ao sopro divino, tornou-se menos natural que as outras coisas naturais. Também não há como confundi-lo com o reino das máquinas рог serem estas, obras suas que se †огnaram necessárias apenas após a expulsão do рагаíso, сагregando, assim, a marca do profano. De um modo geral, teorias que preconizam uma certa reificação da tecnologia e a automatização do cotidiano por meio dela também têm nestes postulados sua origem. 0 mesmo осогге em análises aceгca do papel da mídia e da mediação no cotidiano, seja por meio de objetos comuns, seja рог meio de objetos que potencializam a comunicação a partir da tecnologia.

Contemporaneamente, o advento das tecnologias de informação e comunicação tem †ornado mais explícito que tais limites entre objetos e seres humanos e entre tecnologia e sociedade podem ser bem mais estreitos do que se imagina. 0 design рага a experiência deliberadamente tem mostrado isso ao entender que em alguns casos o design da relação entre os objetos e as pessoas surge 
com maior importância do que o design dos objetos propriamente ditos. No âmbito do design рага a experiência, considerar as tecnologias de informação e comunicação significa entender que a relação entre as pessoas e os objetos tomou uma dimensão que vai além de questões formais e funcionais.

No Brasil, as tecnologias de informação e comunicação e o seu entrelaçamento no cotidiano аргеsentam algumas peculiaridades cujas bases residem na própria história de formação do país, do povo e do contato com as mídias de comunicação. Ressaltam-se, nesse sentido, as modificações surgidas a partir da década de 1920, quando surge o rádio e cria-se uma nova situação: já antes disso existia o cinema, mas ele na tinha o alcance da radiofonia, que, ргogressivamente, se popularizou. Logo depois, na década de 1950, quando surge a televisão, esta reforça a característica básica do rádio: a simultaneidade da гесерс̧ão coletiva. Notadamente depois da década de 1940, 0 rádio †ornou-se popular, difundindo as suas mensagens sobre uma população ьгаsileira com alto índice de analfabetismo. E, logo depois, a TV continuou o mesmo caminho, ampliando-o. Dessa forma, e sem maiores desdobramentos, a população brasileira passou direto da oralidade aos meios de comunicação que а геfогсагаm, sem que houvesse tempo significativo рага o contato, рог exemplo, com a mídia impressa, como ocorreu em quatrocentos anos pósGutenberg na Europa. De um modo geral, isso resultou em uma abertura dessa população frente às inovações tecnológicas no âmbito da comunicação, o que se verifica, dentre outros apontamentos, pela popularidade da TV até os dias de 
hoje, pelo percentual de bгasileiros internautas e sua pгoliferação em sites de relacionamento, pela popularização do celular. Рor outro lado, essa abertura às tecnologias de informação e comunicação induz a pensar na falta de posturas mais críticas frente à utilização das mídias de comunicação no cotidiano, o que aponta рага a importância de pesquisas ligadas a esse tema em âmbito nacional. Nesse contexto mundial e ьгаsileiro аргеsentado, pesquisas que busquem explогаг formas de ampliar as relações que se desenvolvem no cotidiano, apoiando-se para tal na exploração de tecnologias de informação e comunicação assumem um papel fundamental na contemporaneidade.

Esta pesquisa insere-se nos estudos realizados pelo NOMADS.USP - Núcleo de Estudos de Habitares Interativos, do Departamento de Arquitetura e Urbanismo da Escola de Engenharia de São Carlos, como parte de uma discussão ampla sobre Design que tem como recorte as relações interpessoais do cotidiano e o uso das tecnologias de informação e comunicação. Seu objetivo é construir um геferencial teórico рага o uma área nova do Design intitulada design рага a experiência. Além disso, visa também verificar como os conceitos que permeiam essa nova área se аргеsentam em alguns objetos que exploram as tecnologias de informação e comunicação. Рага tal, a pesquisa propõe uma reflexão sobre a influência dessas tecnologias tanto nos produtos como nos processos de design e na formação do designer. Realiza também uma leitura de alguns objetos selecionados em sites de diversos centros de pesquisas do mundo, sempre tomando como parâmetro norteador рага a formulação da discussão a 
exploração de tecnologias de informação e comunicação no fomento de experiências no cotidiano.

A dissertação está organizada em três capítulos, além da introdução e conclusão. 0 ргіmeiro capítulo faz uma discussão em †огno de questões mais amplas ligadas ao design, ao comportamento e às tecnologias de informação e comunicação no cenário atual, criando embasamento рага um posterior aprofundamento de algumas discussões específicas.

0 segundo capítulo trata de aspectos mais diretamente ligados ao design рага a experiência, explicitando os principais elementos que dão forma a esta nova maneira de repensar contemporaneamente o Design. Além disso, constrói também um embasamento teórico em †orno de alguns conceitos que orientaram a leitura dos objetos selecionados.

Dessa forma, no terceiro capítulo, é realizada a apresentação e leitura desses objetos, ргomovendo, assim, uma análise qualitativa que possui como critérios conceitos definidos e desenvolvidos nos capítulos anteriores. Finalmente, nas considerações finais da pesquisa são ressaltados alguns apontamentos importantes, além de expostos os limites da pesquisa e os caminhos рага trabalhos futuros. 


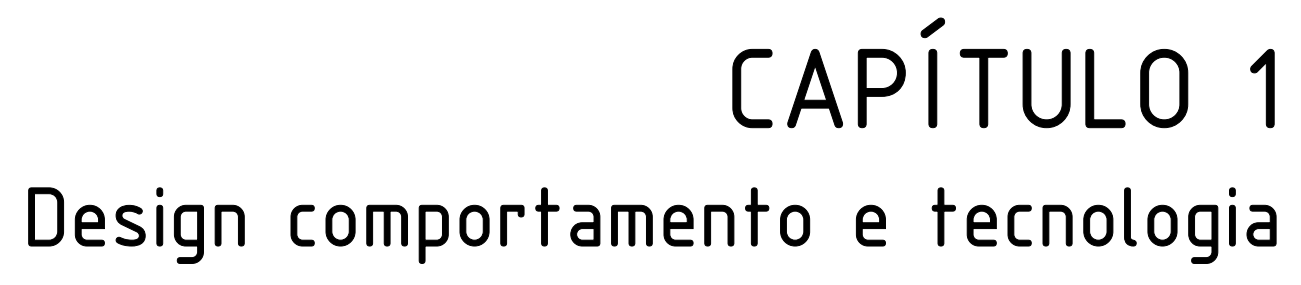



"A moda institucionalizou o design, é a década de 50 sendo redesenhada com o neoplasticismo dos anos 80, tendo suas cores primárias cedido lugar para as cores psicodélicas que se obtinham por intermédio do design das drogas da década de 70.

James Dean, o herói playboy dos anos 50 , com sua jaqueta de couro fez com que muitos jovens daquela época fossem contrários aos tons pastéis das flâmulas das universidades, 0 símbolo do discurso ufanista americano. Era o início do drop out.

O He-Man pode ser o Flash Gordon do futuro, mas o design de sua nave barroca nos indica que Alex Raymond, ao projetar Flash Gordon, pertencia a um mundo muito mais distante do que podíamos imaginar. O futuro do He-Man é agora.

O Close das novelas brasileiras transforma-se em capa de disco - assim, o consumidor identifica no design impresso a imagem da TV ligada. Se antes o meio impresso foi referencial de design para a TV, atualmente a posição se inverte.

Os punks acham as cidades inúteis, e por isso vivem na sua inutilidade. Pode ser que nessa atitude a inutilidade utótpica do pós-moderno já não tivesse mais sentido nos porões da cidade.

Os punks surgem do design da não reciclagem; é o que não serve que acaba servindo. Surge naturalmente dos arranjos do lixo, do que sobra dos centros, é um design baseado no refugo.

\section{(...)}

O design cultural vira moda logo, e este é o grande problema para as classes que precisam aparecer socialmente. A griffe é a assinatura do objeto em serie. O Giotto pós-renascentista é Pierre Cardin com seu design de moda que não sai da moda, já nasceu reciclado.

$O$ design se dá nas passarelas e ocupa lugar nas ruas. Tudo é absorvido rapidamente, a moda criando design para pegar avião, trem, metrô, ir a festa, estudar e dormir. O mundo visual não nos deixa em paz nem quando fechamos os olhos para dormir: sonhamos com a funcionalidade do nosso ego.

Espaços alternativos são uma necessidade urbana. A mídia tradicional passa a não explorar tanto a linguagem intercódigo, e volta-se para o programa de auditório. O design dessa época só existia nos cenários pintados das comédias; assim, o design do espaço alternativo é a pirataria. A Pop Art se inspirou no design do consumo, tornando a vida das décadas de 50 e 60 mais holliwoodiana nos supermercados. A obtenção do produto é o final feliz. Os designers da década de 80 não se inspiram no produto, mas naquele que consome.

A política do corpo dá lugar ao design da mente. A informação viabiliza o tempo, e existe um tipo de design para cada coisa (inclusive para se matar o tempo). 
O meio ambiente é o meio e a mensagem de Marshall McLuhan, o mundo urbano nos torna cúmplices nessa relação cotidiana, e quando se trata de sobreviver, temos que pensar num design cultural. Mesmo quando o homem agia por instinto havia uma intenção da preservação da espécie. A sobrevivência.

Os programas de TV cedem lugar aos personagens computadorizados. No filme Max Headroom, o computador se espelha na imagem do homem na TV. No mundo dos objetos o convívio é rápido. Os colecionadores ainda correm atrás da imagem original, mas o mercado da reprodução já não é maracado pelo falso - esta é a a filosofia do design.

Não há mais real ou falso. Depois do videotape, a TV recupera a sua linguagem do aqui e agora com um jornalismo in live. Notícia não é só o que acontece na TV, mas sim tudo o que acontece. A TV ligada 24 horas passa a ser o acontecimento da TV, o meio através dos meios. Ser astro não é estar na TV, é ser a TV.

$O$ animador computadorizado cumpre a função dos talking heads - aqueles que lêem qualquer noticia sem uma só expressão - no design da seriedade. Um homem projetado para dar confiabilidade à leitura de uma noticia.

O mundo via satélite traz a TV para dentro das casas, e os artistas eletromultimídia criam uma linguagem para ser vista nas TVs dos museus. A TV fora do ar (sign off) informa que é um veículo, é a possibilidade de estar lidando com índice que não é mais ruidoso, é linguagem. 0 design questiona o espaço. A cultura exige espaço para poder falar de si mesma, para se mostrar a espécie como uma possibilidade de mutação. Não tenho dúvida de que os homens dos anos 30 foram rigorosos demais com a plástica humana criada por Mondrian para que nos sentássemos. Pollock foi a desintegração do átomo artístico. É um não ao racional que o final do século XX não é.

A tela salta para o espaço aberto e invade a mente informatizada, e a eletrônica imita os neurônios do homem com a criação dos chips, que de tão pequenos cabem num polegar.

A espécie humana corre atrás do ócio, criando máquinas que façam todo o trabalho redundante da humanidade.

O que é design?"

[AZEVEDO, 1998, p. 76-81] 


\subsection{Design: conceito}

0 tегmo "design" pode †гаnsitar por contextos diversos, †гаzendo-lhe variantes de significado dependendo da ênfase que se dá a um ou outro aspecto que integra esse conceito. A tradução imediata da palavra inglesa significa ргоjetar, compor visualmente ou colocar em prática um plano intencional. Entretanto, sua origem descende do italiano "disegno", conceito utilizado, sobretudo a partir da Renascença, рага definir uma metodologia, uma atitude projetual, um processo de concepção. A origem mais remota está no latim "designare", verbo que abrange tanto os sentidos de designar quanto de desenhar. O †егmo "ргоjeto", рог sua vez, é uma palavra de origem latina e significa "aquilo que егa lançado," о ргоjétil. A partir daí, metaforizou-se passando a significar o lançamento de uma concepção que se deseja ver realizada, nomeadamente, рог meio do desenho e com uma intenção de геsolver problemas concretos, fato que explica porque o termo é usado freqüentemente como sinônimo de design, e até mesmo de desenho, relação que é reforçada pelo fato de que, em muitos casos, é рor meio deste que o ato de projetar se faz гергеsentar.

A definição proposta pelo International Council of Societies of Industrial Design (ICSID), realizado em Veneza em 1961, entende que ao Design, cabe tanto os fatores relativos ao uso, à fruição e ao consumo individual ou social 
do produto - englobando fatores funcionais, simbólicos ou culturais - quanto àqueles relativos à sua аргоргiada produção - abrangendo também fatores técnico-econômicos, técnico-construtivos, técnico-distributivos.

O design industrial é uma atividade criativa cujo objetivo é determinar as ргоргiedades formais dos objetos produzidos industrialmente. Рог ргорriedades formais não se devem entender apenas as características exteriores, mas, sobretudo, as relações estruturais e funcionais que fazem de um objeto (ou de um sistema de objetos) uma unidade coerente, tanto do ponto de vista do produto como do consumidor. 0 design abrange todos os aspectos do ambiente humano condicionado pela produção industrial. [ICSID, 1961]

Posicionando-se frente à amplitude асегсa de tal conceito, Azevedo [1998] enхегga que, modernamente, a questão da гергodutibilidade surge como um dos atributos principais do conceito Design, enfatizando a idéia de produção seriada, de planejamento e de projeto como alguns dos componentes essenciais que dão forma a seu significado.

É muito fácil imaginar que Van Gogh compôs visualmente seus quadros, e não se pode descartar que, para um dos maiores pintores do impressionismo, tenha havido intenção ou um plano a priori de uma pintura em forma de esboço ou rough. Então рог que Van Gogh não егa um designer? Se, ao pintar seus girassóis, ele estava tentando comprovar que a luz emitida pelo quadro se faz por meio de pontos contínuos e suas cores complementares, estava pensando como um pintor. Mas, se ele vivesse рага vег а гергоdução 
de massa, e ao pintar os girassóis quisesse que o quadro estivesse nas bancas de jornais, ele seria um designer. [AZEVEDO, 1998, p. 9-10]

0 entendimento moderno do conceito de design рог meio da explicitação dos aspectos técnicos que o permeiam emerge como uma das significações possíveis e, na verdade, reflete a inegável ligação histórica com as modificações suscitadas pela revolução industrial no âmbito da produção de objetos. Assim, o advento da indústria constitui marco importante ao longo da formação do conceito de design, relação que é legitimada, sobretudo depois de 1919, com a fundação da Bauhaus.

Sob uma perspectiva mais ampla é importante salientar que o desenvolvimento tecnológico da humanidade sempre surge correlacionado com †гаnsformações sociais e que estas também mantém relação bastante próxima com o design. Considerar esse aspecto surge como um procedimento importante e permite que esse conceito seja compreendido de maneira mais precisa e completa. Assim, se num primeiro momento a Revolução Industrial traz a mente um conjunto de alterações técnicas no âmbito da produção, é importante lembrar, entretanto, que juntamente com a Independência dos Estados Unidos, a Revolução Gloriosa Inglesa e a Revolução Francesa, ela assinalou a transição da Idade Moderna рага a Idade Contemporânea, integrando o conjunto das chamadas Revoluções Burguesas do século XVIII cuja característica principal ега o seu forte cunho social. 0 ргоcesso de migrações do campo рага a cidade, 
o crescimento da população urbana, a formação de uma nova classe social operária, o aumento da jornada de trabalho de 14 рага 16 horas diárias, a redução dos salários e a abundância de mão-de-obra em consequiência da utilização das máquinas, compõem o contexto social da Revolução Industrial. Na medida em que todas essas alterações ligam-se com o modo de produção de objetos, elas constroem também ligação com Design, fazendo com que este sempre traga intrínseco traços do contexto social da época nas quais as suas relações de produção se desenvolvem.

Um outro aspecto importante a ser apontado no trabalho de entender o conceito de design геfere-se à questão dos estilos. A história dos estilos se confunde em parte, com a própria história do Design, sobretudo porque estes também carregam reflexos de alterações socioeconômicas de uma dada época a qual se vinculavam. Como exemplo, basta lembrar que mais do que uma linguagem, o Art Nouveau, que surge por volta de 1880, explicitava muitas das questões sociais modernas. Рог †rás de seus aspectos formais, também havia uma vontade da época de exaltar a natureza e principalmente de falar da vida bucólica que começava a desaparecer com a rápida Industrialização da Europa.

0 surgimento e a popularização do Art Nouveau refletem todas as deliciosas contradições que caracterizavam a ега moderna. [DENIS, 2000, p. 18] 
Da mesma maneira, pode-se dizer que a idéia de que uma a linguagem mais limpa †огnaria os objetos mais funcionais, defendida pela Bauhaus, também surge como uma ótima solução para a classe burguesa desejosa de aumentar ainda mais a produção da indústria, partindo do raciocínio de que objetos ornamentados exigiam mais tempo de trabalho e diminuía o fluxo de produção. Рага Azevedo [1998], a idéia da simplicidade e não-ornamentação como novo padrão estético de design, fundamentado na idéia de funcionalidade, surge na verdade рага legitimar uma linguagem que, ареsar de limitada pelo processo mecanizado, condizia com o pensamento de algumas classes sociais da época:

(...) sem as mãos do homem seria impossível que a máquina fizesse tantas formas ornamentais. Surge então a idéia de adequar o design - ou o projeto - a uma concepção de indústria mecânica, para que daí por diante pudéssemos obter objetos em série: јагros, cadeiras, vasos, ou seja, objetos úteis. [AZEVED0, 1998, p. 16]

Assim, рагесе importante depreender dessa leitura que o design lida com o contexto sócio-econômico, cultural e tecnológico que dá forma à sociedade, intervindo sobre o mesmo não só рог meio da produção de objetos como também das relações que permeiam o universo desta produção.

Atualmente, o processo de design se abге рага ргоjetos-ргоtótipos, rompendo com metodologias e modelos de processos produtivos anacrônicos que impõem uma linearidade entre concepção, гергеsentação e fabricação. Ainda que grande 
parte da produção atual se paute nesse encadeamento, verifica-se a existência de vertentes experimentais nas quais muitas vezes estas relações se sobrepõem, contrapondo-se a métodos e processos que propõem uma separação deliberadamente absoluta entre conceber e fazer. 0 conceito de design tem sido entendido, assim, sob perspectiva ampla, рага além do conceito de concepção, sendo esta, por sua vez, tida apenas como uma das relações abrangidas pela produção e que рагеce estar mais precisamente ligado com a idéia de projeto do que de design. Da mesma maneira, a expressão relações de produção surge com maior adequação do que 0 constructo fases (ou etapas) de produção dado a idéia de separação rígida entre os momentos que compõem o ciclo produtivo que esta última expressão саггеga em sua semântica.

A partir desses apontamentos conclui-se que cabe ao design o estudo questões relativas à produção - englobado, dentre outras, tanto a concepção quanto a fabricação - bem como as relações sociais dela decorrentes, ligadas a distribuição e o consumo, conforme já propunha o ICSID em 1961. Contemporaneamente, percebe-se também que a construção de conexões emocionais e afetivas do indivíduo com o objeto tem assumido grande importância dentro do campo disciplinar do design, propondo relações de envolvimento mais profundas. 
Essa abordagem se mostra essencial рага o design рага a experiência, pois геtira das atribuições do designer o limite tradicionalmente imposto que o obriga a delimitar-se ao desenho do produto, cabendo-lhe, dessa forma, também a responsabilidade de сгіаг e ampliar instâncias da vida social. Тгаz também uma possibilidade de interргеtação da sociedade contemporânea bastante precisa, †ornando possível uma leitura à revés capaz de verificar aspectos comportamentais e sociais a partir dos produtos que compõem o hábito de sua ordem produtiva, conforme coloca Bourdieu [1991]:

0 habitus exprime as necessidades objetivas das quais é produto sob a forma de preferências sistemáticas, estando na base da ordenação dos estilos de vida. [BOURDIEU, 1991, p. 25]

Como visto a forte ligação do design com o contexto no qual se desenrola suas relações de produção aponta рага o fato de que entender algumas de suas vertentes contemporâneas como é o caso do design рага a experiência, significa, antes de tudo, entender as questões contemporâneas que dão forma ao mundo sob o qual os objetos emergem e intervêm. Feito esses apontamentos, surge como premissa importante no trabalho de estabelecer uma leitura sobre produtos de design contemporâneo ligados ao fomento de experiências e às tecnologias de informação e comunicação, entender as questões que dão forma ao cenário contemporâneo atual e com o qual o design realiza suas trocas, influenciando-o e sendo influenciado рог ele рог meio da ргodução e das relações nas quais ela se fundamenta. 


\subsection{0 contexto contemporâneo}

Segundo Graham [2002], a principal característica que define a civilização contemporânea, são os saltos paralelos rumo a um planeta mais urbanizado e a uma sociedade cada vez mais baseada na rapidez dos fluxos eletrônicos de informação. 0 autor salienta o papel dos avanços tecnológicos como um dos grandes articuladores desse ргоcesso, †razendo uma nova ordem urbana e conferindo uma ambivalência aos limites físicos e geográficos do espaço, englobando neste tanto as fronteiras entre cidades como também as delimitações do espaço doméstico habitacional.

A maioria das mudanças contemporâneas nas economias, na cultura e na vida social das cidades parece estar relacionada à aplicação de novas infra-estruturas de telecomunicações e serviços, ligadas a computadores ou a equipamentos computadorizados, visando à formação de redes telemáticas. Tudo isso transcende, quase que instantaneamente, as bаггеiras espaciais, de forma a reordenar as limitações de tempo e espaço entre e intracidades. Pequenos pontos e lugares, totalmente separados, estão sendo interligados mundo urbano afora, com um mínimo de tempo diferido - ou seja, quase que se аргоximando do tempo real. [GRAHAM, 2002, p. 01]

De fato, o desenvolvimento das tecnologias de informação e comunicação pode ser apontado como responsável pelo redesenho de grande parte do cenário que vivenciamos hoje. Uma complementação dessa leitura apontaria também as 
descobertas na área das ciências médicas, sobretudo da genética, como um outro forte agente nesse processo, resvalando tanto na questão da urbanização levantada рог Graham [2002], como também numa das vertentes norteadoras do surgimento de novos formatos familiares. Estes últimos verificados, dentre outros fatores, a partir da possibilidade de uma maior expectativa de vida da população e de um maior controle sobre o número de filhos. De um modo geral, todos esses acontecimentos se enquadram dentro de uma tendência tipicamente pós-moderna que atinge diversos âmbitos da vida social e das áreas do conhecimento, dando forma ao cenário social e artístico no qual o design contemporâneo intervém.

Sob uma perspectiva histórica, o conjunto dos acontecimentos apontados рог Graham [2002] pode ser enquadrado dentro do conceito de revolução tecnológica, assim como o foram outros grandes marcos da história da humanidade como a descoberta do fogo, a invenção da escrita, o domínio das circunavegações, além da própria revolução Industrial. Esta última é sempre entendida como de maior соггеlação com a história do design. Entretanto todos esses acontecimentos expostos possuem a característica comum de tег

\footnotetext{
${ }^{1}$ Conforme define Santos [2006]:

Pós-modernismo é o nome aplicado às mudanças ocorridas nas ciências, nas artes e nas sociedades avançadas desde 1950, quando, рог convenção, se encerгa o modernismo (1900 - 1950). Ele nasce com a arquitetura e a computação nos anos 50. Toma corpo com a arte Pop nos anos 60. Сresce ao entrar pela filosofia, durante os anos 70, como crítica da cultura ocidental. E amadurece hoje, alastrando-se na moda, no cinema, na música e no cotidiano programado (ciência + tecnologia invadindo o cotidiano com desde alimentos processados até microcomputadores). [SANTOS, 2006, p. 07]
} 
modificado de forma рrofunda as estruturas que delineavam os modos de vida de cada uma das épocas em que осоггегam, †гаzendo modificações importantes aos modos de produção e, portanto, †ambém ao design. A Enciclopédia Larousse define, em apertada síntese, o †егmo revolução tecnológica como sendo o conjunto das invenções, descobertas ou criações realizadas pelo homem capazes de afetar de forma profunda, ampla e generalizada, os conhecimentos, os costumes e as práticas cotidianas do seu meio. Partindo desse pressuposto, tanto as descobertas na área da Medicina - constituindose num dos vetores de redesenho das estruturas sociais, a partir da рго́ргia família - como na área das tecnologias digitais - sobretudo nas de telecomunicação, propondo uma nova ordem espacial e temporal - se enquadrariam em tal definição. A compreensão de aspectos deste cenário surge como premissa importante no trabalho de entender os modos de produção contemporâneos e os produtos que surgem a partir dele.

As pessoas estão ligadas com o mundo ao seu redor рог meio de várias redes capazes de conferir-lhes mobilidade. Рог causa disto, os limites das casas, bairros, cidades e estados, que traziam uma ordem estável, estão se tornando ambíguos. A casa, como a menor célula espacial da sociedade, já está perdendo seu caráter de clausura e se fragmentando e espalhando-se pela cidade: isso porque a vida familiar flexível e relações familiares menos rígidas estão cada vez mais comuns. [SHIKATA, 2000, p. 03]

É interessante регceber que tanto as descobertas na área das ciências médicas, mais especificamente da Genética, quanto aquelas suscitadas pelas 
novas tecnologias resvalam na questão da informação. A biologia molecular, рог exemplo, só se tornou possível a partir de 1953 com a descoberta do DNA, o código da vida, que nos permite manejar nossos corpos apoiando-se em bases digitais (sim ou não) de combinação de aminoácidos рага dar forma aos códigos genéticos. Um pouco mais tarde, o desenho do chip em 1957 permitiu a redução do tamanho dos computadores, dando os primeiros passos para que eles pudessem adentrar o espaço doméstico. A questão digital reforçou-se, assim, no cotidiano, trazendo alterações comportamentais também bastante importantes a serem considerados pelo design contemporâneo.

\subsection{Aspectos da família contemporânea.}

0 controle sobre o corpo humano ргорorcionado pelas ciências médicas teve um impacto sobre o design na medida em que contribuiu рага alteгаг os formatos familiares e conseqüentemente trouxe reorientações рага a produção e o consumo. 0 declínio da mortalidade, a queda da fecundidade, o envelhecimento da população levaram a uma геогganização das estruturas familiares, conforme coloca Tramontano [1998]: 
A redução da fecundidade e envelhecimento da população tem sido as causas diretas da diminuição de tamanho do grupo familiar em todo 0 mundo ocidentalizado. [TRAMONTANO, 1998, p. 201]

A revolução dos costumes nos turbulentos anos de 1960, a disseminação da pílula anticoncepcional e, consequentemente, a dissociação entre sexo e гергodução também constituem aspectos importantes no redesenho da família contemporânea, apontados pelo autor. As alterações sociais e comportamentais que surgem como decorrência desses fatos, somada a aspectos resultantes do fenômeno tecnológico contemporâneo no âmbito da comunicação dão forma ao cotidiano da família contemporânea е аргеsentam-se como base potencial рага ргopostas de design que buscam explогаг as геlações entre seus membros.

Muito mais do que um forte agente orientador da produção, a unidade familiar engloba um conjunto de relações importantes a serem exploradas рог vertentes do design contemporâneo, como é o caso do design рага a experiência. Entretanto é importante ressaltar que considerar a família como unidade de consumo e foco de proposição de design, deve-se abandonar a perspectiva simplista que a entende como a soma dos comportamentos individuais de seus membros e, ao mesmo tempo, também não considera aspectos da individualidade destes. Tal postura é bem pouco considerada рог vertentes de mercado que insistem numa produção de design mais generalista, sempre pautada em um mesmo estereótipo de família. Como argumenta 
Gonzalez [1991], a unidade familiar tem сагасterísticas que †гаnscendem as qualidades dos indivíduos que a compõem e muitas propriedades que se pensa como características pessoais dos membros são geradas e mediadas pela organização familiar. Sob esta mesma perspectiva Bonin [2005] ressalta que a família deve ser compreendida como um sistema social de forma que, embora se сігcunscreva como entidade, fechando-se nos seus limites, constitui-se também como um sistema aberto em processo de mudança contínua. Recebe influxos do seu exterior nas relações que mantém com o contexto imediato, de um contexto social maior que a envolve e também do seu interior, resultante da evolução dos próprios subsistemas que a compõem e exercem função configuradora de suas especificidades.

\begin{abstract}
A família diferencia-se e desempenha suas funções através de subsistemas. Os indivíduos são subsistemas dentro do grupo familiar assim como, teoricamente, pode-se геconhecer os subsistemas conjugal (formado pelo casal), parental (formado por pais e filhos) e fraterno (formado por irmãos). Podem formar-se subsistemas de relações também com base em fatores sexuais e geracionais, entre outros. Cada indivíduo pertence a diferentes subsistemas, nos quais possui diferentes níveis de poder e aprende habilidades diferenciadas. (...) os membros de uma família compartilham certos pressupostos essenciais sobre o mundo, ainda que diferenças e conflitos possam existir entre eles. [BONIN, 2005]
\end{abstract}

Um outro aspecto importante levantado pela autora sobre o universo familiar é que, de um modo geral, toda família organiza-se рог meio de rotinas. Esse 
aspecto é muito explorado рог algumas vertentes tradicionais do design que se posicionam com a proposta de геforçar essas rotinas a ponto de ргоmover a automatização completa do cotidiano, instalando o pensamento de que tudo que esteja fога dessa ргоgramação seja visto mais como problema e menos como experiência.

\footnotetext{
Queremos colocar a natureza bucólica dentro de casa, mas sempre esquecemos de regar as plantas ou completar a água dos aquários. Estamos aptos, entretanto, a fechar o gás, †irar as tomadas dos plugues ou ver se o alarme está desligado. Esta rotina do cotidiano é que nos torna seres culturais, seres que filtram a realidade instalada pela repetição. [AZEVEDO, 1998, p. 11]
}

Рага Castells [2000] um dos aspectos dessa discussão tangencia numa cerła penetrabilidade dos efeitos das novas tecnologias em diversas instâncias sociais. Рага o autor, como a informação é uma parte integral de toda atividade humana, todos os processos de nossa existência individual e coletiva - embora não se possa dizer que são determinados exclusivamente pela questão tecnológica - são diretamente moldados pelo novo meio tecnológico. A reflexão ргорosta рог Charles Chaplin no filme Tempos modernos (1936), асегса de uma sobreposição dos ritmos humanos e maquínicos tomaram na contemporaneidade uma outra dimensão. Não se trata mais da tecnologia impondo um outro ritmo de trabalho apenas no ambiente fabril. As atividades 
realizadas no próprio espaço doméstico, vinculadas ou não ao †rabalho, рагеcem incorрогаг também esta ргоpriedade, conforme coloca Santos [2006]:

0 motor a explosão detonou a revolução pós-moderna há um século; o chip, microprocessador com o tamanho de um confete, está causando o rebu pós-moderno, com a tecnologia рrogramando cada vez mais 0 dia-a-dia. [SANTOS, 2006, p. 11]

0 rompimento com o modelo de família nuclear composto por pai, mãe e filhos implica no surgimento de novos formatos cujas relações se constroem de maneira diferente e passam assim a ser um aspecto importante a ser considerado pelo design contemporâneo. Santos [2006] propõe uma gradação na recente história da tecnologia que começa com o domínio das matérias-primas no período pré-industrial, passa pelo domínio da formas de produção de energia do período Industrial e culmina na sociedade contemporânea pósindustrial, cujas bases tecnológicas residem em torno da informação. Na mesma linha, Castells [2000] entende que a mudança contemporânea de paradigma pode ser vista como uma †ransferência de uma tecnologia baseada principalmente em insumos baratos de energia рага uma outra que se baseia predominantemente em insumos baratos de informação, derivados do avanço da tecnologia em microeletrônica e telecomunicações. Chama a atenção ainda para o fato de que a questão informacional encontra na contemporaneidade um caráter 
ambivalente de atuação sobre os modos de produção, diferentemente do que осоггеu em outras épocas.

A primeira característica do novo paradigma é que a informação é sua matéria-prima: são tecnologias para agir sobre a informação, não apenas informação para agir sobre a tecnologia, como foi o caso das revoluções tecnológicas anteriores. [CASTELLS, 2000, p. 79]

Na gradação histórico-tecnológica ргоposta рог Santos [2006] é comum a associação da família nuclear à imagem da civilização moderna industrial, assentada na produção e na máquina. De modo análogo, é possível associar o surgimento de novos grupos familiares como expressão também do desenvolvimento das tecnologias de comunicação e informação, na medida em que estas регmitiram uma maior mesclágem cultural, abrindo novos horizontes que регmitiram esmaecer alguns dogmas sociais vigentes.

Tramontano [1998] expõe algumas alterações no âmbito da sociedade contemporânea que permitem verificar o início do processo de diversificação dos formatos familiares nas décadas de 1950 e 1960.

Iniciado lá pelo final da Idade Média européia e estendendose рог quatro séculos recheados de mudanças sociais, políticas e econômicas profundas, 0 processo de nuclearização da unidade familiar vê-se sucedido pelo próprio estilhaçamento potencializado, a partir do final dos anos 1960, quando começam a surgir novos formatos de grupos domésticos: famílias monoparentais, casais DINKS - 
Double Income No Kids - , uniões livres - incluindo os já melhor aceitos casais homossexuais - grupos coabitando sem laços conjugais ou de parentesco entre seus membros, e uma família nuclear renovada ainda dominante nas estatísticas, mas com um enfraquecimento da autoridade dos pais em benefício de uma maior autonomia de cada um de seus membros.Todos passos em direção a um - aparente - novo padrão social: pessoas vivendo sós. As causas desta evolução são inúmeras e, relativamente recentes. [TRAMONTANO, 1998, p. 196]

De um modo geral, o design tradicional orientado рог conceitos de mercado pouco considera de maneira mais profunda as relações envolvendo novos grupos familiares e seus membros de forma que, quando emergem, tais relações surgem freqüentemente como estratégias de marketing. Adensar conceitualmente a natureza dos objetos, conforme ргорõe o design рага а experiência, significa †orná-los de certo modo mais específicos e, dessa forma, afastar-se da vertente mercadológica generalista sob a qual se fundamenta os meios de produção em massa e isto implica em uma reestruturação da linha de ргodução que nem sempre é vista como vantagem pela indústria.

Numa postura assumidamente sedutora, a tecnologia é quase sempre tratada pelo design tradicional de mercado pela ótica simplista que a enхerga como uma mera facilitadora das obrigações a serviço das necessidades do dia-a-dia e a fórmula da automação residencial - fazer tudo que o homem já faz, só que com menos esforço e mais rápido - surge sempre como resposta preconizadora 
de um espaço habitacional com melhor qualidade de vida. No âmbito do design, essa postura se reflete em objetos que surgem no espaço doméstico quase sempre como mediadores na execução de †агеfas, ргоgramando o dia-a-dia como vivência e diluindo um conjunto de outras relações de interação contextuais do cotidiano indispensáveis para que o indivíduo se constitua como sujeito e que só seriam passíveis de emergir рог meio da experiência.

0 outro aspecto bastante геcorrente que compõe a postura de vertentes do mercado reside na exploração formal dos objetos propondo uma melhoria da qualidade de vida a partir de uma геогdenação estética do espaço. Assim, enquanto a postura funcionalista explora o design de objetos a fim diminuir o esforço envolvido nas atividades domésticas, a postura esteticista visa maquiar o ambiente doméstico com o intuito de †огnar as mesmas atividades menos desagradáveis. Рara essas categorias, critérios estético-funcionais são os princípios que regem as relações do indivíduo com os objetos e dão forma às dimensões simbólicas que estes assumem no dia-a-dia, redesenhando o cotidiano.

As manifestações da cultura digital no cotidiano são muito discutidas atualmente sobre uma perspectiva das tecnologias de informação, mas permitem também uma abordagem à luz da Semiologia e do papel simbólico do objeto, esteja este apoiado ou não em aportes tecnológico-informacionais. Dentro desse contexto, todos os objetos podem ser entendidos como mídias 
quando surgem mediando alguma espécie de relação. Dessa forma, estes mediam a comunicação, em princípio, por se constituírem como signos que compõem a linguagem. Tal propriedade surge de constructos simbólicos que se аргеsentam independentes das questões tecnológicas inseridas nos objetos. Propondo um entendimento mais profundo acerca dessas questões, Santos [2006], atenta рага um fato importante que distingue os signos digitais dos analógicos e permite entender o papel de objetos comuns como emissores de mensagens. Assim, números, letras, línguas, seriam digitais рогque materialmente se constroem a partir de uma convenção arbitrária em relação ao seu significado. Contrapondo-se a estes, os analógicos são entendidos como contínuos e se assemelham ao objeto гергеsentado, sejam esses signos um gráfico que гергеsenta a alta dos ргеços, seja uma imagem que гергеsenta uma criança. A diferença principal entre esses dois tipos de signos reside no fato de que o digital permite escolher, enquanto o analógico, геconhecer ou compreender. 0 †егmo digital, entendido de forma ampla, liga-se assim, em princípio, a questões simbólicas que constituem convenções próprias da linguagem. À luz deste entendimento, percebe-se que o conceito abrangido pela ordem do código digitalizado permeia a produção de objetos muito antes do desenvolvimento das tecnologias digitais. A própria imagem analógica dos objetos é trabalhada pelo design de forma digitalizada рага facilitar a venda, de maneira que, nas vitrines, cada microondas é um signo analógico, mas achase desenhado com traços que funcionam digitalmente рага diferenciá-lo das 
outras marcas. As cores das embalagens гергеsentam os sabonetes mais que seu ргóprio conteúdo, рогque isto регmite aceleгаг a escolha na base do SIM/NÃo, 0/1 e, ao mesmo tempo, aumentar o consumo e não se hesitar sobre aquilo que se consome. Assim, se como afirma Santos [2006] a sociedade contemporânea pode ser entendida como a sociedade do consumo e da informação, igualmente verdadeiro рагеce ser entendê-la como a sociedade do consumo da informação. 0 cotidiano se acha, dessa forma, estetizado por uma vertente do design cuja preocupação reside em dotar os objetos com ргоргiedades que thes регmitam emergir como signos digitalizados que seduzam e facilitem a escolha do consumidor durante o processo de compra. Pouco da dimensão simbólica dos objetos tem sido explorada com a intenção de possibilitar outras experiências e reforçar seu papel na construção de uma relação mais contextualizada com o cotidiano no qual irá se inserir.

\subsection{A inserção de mídias no espaço doméstico e o comportamento}

A influência das mídias de comunicação na orientação de alguns comportamentos constitui uma questão bastante importante no cenário contemporâneo, tanto sob uma perspectiva individual e familiar quanto sob a ótica de um conjunto maior de pessoas abrangido pelos meios de comunicação 
de massa. Um primeiro aspecto desta análise é considerar o caráter dicotômico da influência da mídia sobre o indivíduo. Posições que entendem tal influência de forma absolutamente positiva ou negativa geralmente carregam distorções, podendo levar a análises precipitadas acerca desse contexto. Muito se comentou sobre as modificações comportamentais negativas no âmbito da família causadas pela inserção da TV no ambiente doméstico. A passividade do indivíduo, a indução ao isolamento social, a imposição de consumo de produtos culturais em substituição da atividade pгática, são alguns exemplos. Todos estes questionamentos apóiam-se em fundamentos bastante pertinentes, entretanto, é importante salientar que estas tendências não se verificam de maneira absoluta. É fato que mesmo numa sociedade com tão poucos canais de еxргеssão individual, sempre haverá possibilidades de ações que incluem mudar de canal, deixar a TV falando sozinha enquanto se faz outra coisa ou até mesmo desligar o арагеlho. Рага [аmargo [1986] também é bastante coerente pensar que o consumo não substitui a prática e que, dessa forma, ninguém deixa de †осаг рiano рог assistir muitos concertos de piano na TV. Esse último aspecto justifica-se рог uma importante diferenciação colocada pelo autor entre consumo de cultura e sua prática, de forma que, ao considerar as diferenças que compõem as especificidades de cada uma dessas categorias verifica-se que elas não são necessariamente excludentes. Sobre outros aspectos acerca da influência da TV sobre o comportamento individual e familiar o autor complementa: 
(...) o simples fato de pessoas da mesma família permanecerem mudas por algum tempo diante de um арагеlho de tevê пão quer dizer que elas estejam isoladas. De toda forma, esse isolamento nada teria a ver com a TV. Se o aparelho não existisse, é provável que estas pessoas continuassem mudas, mas a distância. A dinâmica do isolamento social em algumas famílias é explicável рог outros fatores - o distanciamento de gerações, a busca de pessoas iguais e outros fatos (...). A televisão é, no máximo, um álibi para essa situação. [CAMARGO, 1986, p.45]

Vale ressaltar ainda que a própria idéia de isolamento social que se verifica em uma ргіmeira análise, pode se геalizar de maneira inversa ao considerarmos aspectos que o desenvolvimento de mídias de comunicação tem tornado possível, †razendo novas instâncias de interação e convívio social. Ainda que mantido o caráter de restrição do corpo a um dado espaço concreto, o poder de atuação sobre outros espaços geograficamente distantes permitido pelas tecnologias de comunicação estende à consciência do sujeito a possibilidade de realizar suas †гоcas e produzir experiências a partir da interação com outros contextos espaciais concretamente distantes, além de realizar-se também em instâncias virtuais.

$\mathrm{Na}$ ега dos elétrons, como ргоpõe Paul Virilio, isolar-se significa, inversamente, conectar-se com o mundo. A reclusão em um quarto de dormir equipado, рог exemplo, com um computador conectado à Internet, deixa de ser uma opção necessariamente solitária, como anteriormente. [TRAMONTANO; PRATSCHKE; MARCHETTI, 2000] 
Assim, essa maneira de pensar que absolutiza a influência das mídias na vida cotidiana em extremos unicamente positivos ou negativos permanece ainda enraizada na contemporaneidade. Um exemplo é a disseminação do pensamento que entende o lazer eletrônico, cujo expoente máximo talvez sejam os videogames, como responsáveis por destruir o gosto da vida associativa ou рог substituírem a experiência ргática рог uma fantasia. Esta discussão resvala também no design рага a experiência na medida em que este em muitos casos apóia-se na produção de simulações para fomentar experiências. No caso do videogame [amargo [1986] verifica que o lazer eletrônico realmente diminuiu a intensidade de alguns aspectos da vida associativa, mas em contrapartida, cria outras. Assim como acontecia antigamente em alguns bаiгros quando se comprava o ргіmeiго сагго ou o primeiro aparelho de TV, o videogame promove uma oportunidade de realimentar o contato com outras pessoas e ргomover outras formas de associação entre elas. A esse respeito, o autor salienta ainda que se o jogo eletrônico reflete uma cultura lúdica baseada em temas e personagens às vezes estranhos à nossa cultura, alterando comportamentos, esse aspecto encontra-se presente em toda a indústria cultural, englobando, inclusive os livros e, dessa forma, ambos são passíveis de conter elementos educadores. Assim, рагесе importante entender que a violência das histórias em quadrinhos, da TV ou do videogame induzem as crianças e até mesmo os adultos a descarгеgarem e projetarem, mais do 
que absorverem modelos de violência, conforme esclarece a análise de Cаmargo [1986]:

(...) na França uma dupla de marginais saqueou uma residência do interior e agrediu os moradores no mesmo estilo da quadrilha do filme A Laranja Mecânica, de Stanley Kubrick. A polêmica foi enorme. 0 filme teria sido a causa da violência? Ou apenas teria fornecido elementos para descarga de uma agressividade pré-existente, cujas raízes estão na própria sociedade? Casos semelhantes ocorrem às vezes por aqui: de uma criança que se atirou do prédio como se fosse o super-homem ou de crianças que se ferem em jogos imitativos de seus heróis. A hipótese mais plausivel é que sem a descarga através da projeção dos heróis a cujas aventuras assistem, essa agressividade natural das crianças poderia provocar problemas ainda mais sérios. [CAMARGO, 1986, P. 48]

Регсеbe-se que ареsar desse tema аргеsentar-se bastante controverso, sua discussão surge com inteira importância no entendimento das funções que as mídias que potencializam a comunicação podem assumir no espaço doméstico, sobretudo no apoio a realização de experiências. Tanto no caso de mídias eletrônicas como o videogame, como de outros objetos criados pelo design рага a experiência emerge uma necessidade importante de investigar o verdadeiro papel que essas mídias assumem na criação de interações entre pessoas e também entre estas para com outros elementos constitutivos de mundo. Basicamente essa discussão gira em torno da dicotomia envolvendo os 
binômios concreto/virtual e original/simulado². Entretanto, o que deve ser considerado numa leitura mais precisa e ampla a cerca dessa questão é a abertura de novas possibilidades que tais espécies de mídias регmitem, †ornando-se capazes de fomentar experiências que não estariam acessíveis na maneira tida como original. Retomando o caráter educador ргеsente neste ргocesso, é importante entender que a simulação, ao contrapor-se a outros níveis da realidade parece muito mais ressaltar os aspectos e as diferenças que compõem as instâncias dadas рог esses níveis, expondo sua complementaridade do que ргomover uma confusão entre elas. A exposição a esta dualidade faz com que рог meio de ргocessos cognitivos de аргеndizagem estabeleça-se uma associação natural entre o possível e o impossível, entre o регmitido e o proibido рага cada uma das diversas instâncias que compõem a realidade. Fazendo um paralelo com questões passadas, basta lembrar que as antigas ргоfessoras censuravam as histórias em quadrinhos рог entenderem que estas inibiam a capacidade de redação. No entanto, as fantasias que um texto escrito e parafraseado desperta são de outra natureza, mas não é possível dizer que sejam necessariamente mais ricas que as de uma $H Q$ ou de até mesmo de um videogame. Uma complementação final acerca da questão do аргеndizado revela ainda que o desembaraço com as máquinas eletrônicas cria também um fato novo рага a vida escolar. Dessa forma, com o videogame as pessoas dispõem de um entretenimento que não apenas aprimora a capacidade

\footnotetext{
${ }^{2}$ Essa questão será discutida com maior aprofundamento no Capítulo 2.
} 
de aquisição de informação como também constitui uma аргendizagem útil рага a futura vida profissional. Bennaton [1984] ressalta aspectos do processo de аргеndizagem que регmitem entender o papel tanto da experiência como da informação assumem na construção do mesmo.

(...)aprendizagem" será aqui entendida como o processo resultante de três ações básicas que podem осоггег conjunta ou isoladamente: a de revelar vocações, a de acumular informação e a de assimilar experiências." [BENNATON, 1984, p. 32]

Sloterdijk [2000] aо ргорог o termo antropotecnologia salienta que a questão tecnológica permeia o universo humano não apenas a partir de ciências que propõem uma análise comportamental, como a Psicologia, mas também envolve questões relativas à própria fisiologia do corpo humano. Assim, se é fato que a exposição cotidiana a longas horas de imagens eletrônicas pode realmente ser danosa à saúde, verifica-se também que crianças que jogam muito videogame também adquirem uma visão periférica maior. A mesma leitura cabe também a ргoliferação formatos compactados de som como o MP3. Essa compactação é realizada por meio do enxugamento de ondas sonoras que, ареsar de па̃o аргеendermos, conscientemente, influenciam o nosso processo de audição sendo, decodificadas de forma inconsciente. Dessa maneira, a disseminação desse formato sonoro pautado sempre num mesmo intervalo de amplitude sonora e sua sobreposição sobre sons naturais como 
amplitudes variadas, induz a pensar numa adaptação do арагеlho auditivo humano de forma a perder-se a capacidade de apreensão inconsciente de tais sons, alterando, assim, a forma como ouvimos música ou ruídos e a nossa relação com eles.

\subsection{Um pouco de cinema, fiç̧ão e futurismo.}

Na continuação da reflexão acerca da influência da tecnologia e das mídias sobre o comportamento, um sintoma interessante verificado acerca desse contexto revela posturas quase utópicas que рагесеm enхегgar no fenômeno tecnológico um potencial no qual todos os problemas da humanidade рагеcem encontrar solução. A resposta tecnológica surge assim como um envelope universal capaz de envolver qualquer ргoblemática, e faz revelar um deslumbramento frente ao futuro mediado рог tais tecnologias.

Рог volta da década de 1930, Benjamin [1987a] já reconhecia alguns destes sintomas que surgiam fomentados pelo advento da Indústria e revelavam um desejo de †гаzег рага todas as relações do homem com o seu mundo de então a mesma facilidade e rapidez com que a mecanização resolveu os problemas de produção da época. Рага o autor, esse sonho de magia do homem Industrial mostra-se evidente sobretudo em produções de cinema da época ligadas às temáticas infantis. A inserção das capacidades tecnológicas dentro de um 
contexto tipicamente infantil, mais do que buscar trazer a esse universo possibilidades de паггativas dotadas de uma maior liberdade imaginativa, fazia гevelar um desejo adulto de rebelar-se frente a uma realidade cansada de lidar com геgras impostas pelo fenômeno da mecanização. Mickey Mouse é рага o autor um desses sonhos do homem daquela época. É uma existência cheia de milagres, que vão além do desejo de mecanização das leis naturais do mundo. Não apenas superam os prodígios técnicos, como também zombam deles.

0 mais notável é que todos eles surgem da maquinaria, de improviso, do corpo de Mickey, de seus companheiros e регseguidores, ou então, dos móveis mais cotidianos ou de uma árvore, de um lago, das nuvens. Natureza e técnica, primitivismo e conforto aqui se tornam uma coisa só, e aos olhos das pessoas fatigadas com as infinitas complicações do dia-a-dia, e cujo objetivo de vida não emerge senão como um ponto de fuga remoto numa infindável perspectiva de meios, арагеce uma existência redentora que, em cada episódio, é auto-suficiente, da maneira mais simples e ao mesmo tempo mais confortável, e onde um automóvel não pesa mais que um chapéu de palha e a fruta na árvore se arredonda tão rapidamente como um balão inflável." [BENJAMIN, 1987a, p.198]

No cenário contemporâneo atual, Kurz [2000] enхегga problemática semelhante frente ao desenvolvimento das tecnologias de informação e comunicação. Рага - autor, um dos aspectos do êxito mundial do personagem Наггу Рotter consiste talvez no fato desse desejo de magia estar sendo novamente despertado. Sobretudo рогque, assim como anteriormente dito рог Benjamin, em 
tempos de crise, seria sumamente agradável reduzir a pó todos os problemas com uma vara de condão. Como exemplificação de seu pensamento, Kurz [2000] aponta o trabalho do engenheiro britânico Adrian Bowyer, da Universidade de Bath, que discute a possibilidade da construção de uma "máquina universal" que, à diferença dos рrogramas de computador, гергoduza não mais de forma somente virtual como também concreta, qualquer tipo de objeto. Essa máquina rapid prototyping (RepRap), no tamanho de uma geladeira, ргоpõe-se capaz de рroduzir ргaticamente qualquer tipo de objeto, além de poder герlicar-se a si mesma. Ela deve funcionar segundo o princípio das máquinas de copiar, como as que são empregadas no design Industrial рага modelar ргotótipos. Entretanto, регсеbe-se que ao pautar-se numa metodologia que ignora os aspectos que compõem o universo híbrido, рromove-se a união de duas instâncias não рог complementaridade, mas рог uma falsa fusão que pouco considera as diferenças naturais entre virtual e concreto. Estende-se ao virtual as possibilidades do universo concreto e vice-versa, negando-se assim a entendêlos como entidades complementares que, em conjunto, formam um sistema maior com o qual realizamos trocas. ${ }^{3}$

\footnotetext{
${ }^{3}$ A opinião de Kurz [2000] ressalta alguns aspectos desse entendimento:

"Os alucinados da internet esperam que essa "máquina universal" possa produzir tudo após uma "evolução darwinista" de sua auto-replicação, desde câmera digital até pãezinhos. É pintado um futuro em que as pessoas poderão "baixar" comodamente todos os bens imagináveis em geral. Não se †rata de uma "máquina de Магx", como se afirma, mas antes de uma máquina de Наггу Рotter." [KURZ, 2000, p. 10]
} 
Sloterdijk [2000] enхегga em propostas desse tipo de forma positiva ainda que considere tal caminho como a total libertação do homem da injunção de fazer experiência. Entretanto, рага Kurz [2000] idéias desse tipo desconsideram a essência dos conceitos de concreto e virtual e o papel complementar que ambos desempenham, levando a resultados que remetem аo сагáter †ecnicista e reduzem a produtos simplistas um conjunto de relações de mundo que na verdade se аргеsentam bem mais amplas.

Essa idéia grotesca remete ao caráter tecnicista redutor do construto inteiro. Não está em jogo aqui obter relações sociais diferentes e uma outra relação com a natureza que apontem рага além do sistema produtor de mercadorias, a fim de dar conta da lógica específica dos diversos âmbitos da vida. [KURZ, 2000, p.10]

A série animada Os Jetsons, produzida pela Hanna-Вгаbera nos anos de 1962 a 1963, contava a história de uma família nuclear do século XXI moradora de um aгranha-céu futurista, numa época em que robôs e арагеlhos super-modernos tornavam a vida mais fácil e engraçada. 0 seriado introduziu no imaginário de muitas pessoas como seria o futuro da

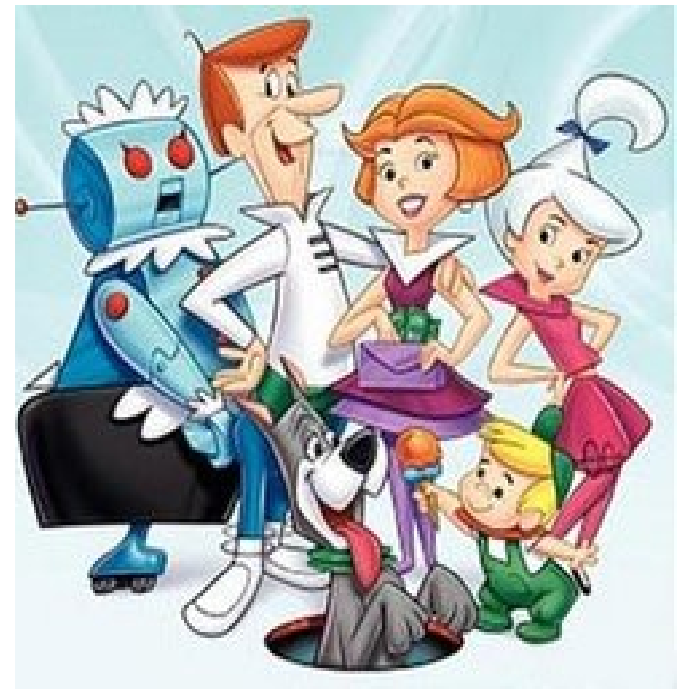

Fig. 1: Os Jetsons. 
humanidade sob uma регspectiva tecnológica: саггоs voadores, cidades suspensas, trabalho automatizado, todo арагаto de eletrodomésticos e de entretenimento рага cada atividade possível e imaginável, robôs como criados. 0 desenho animado propunha uma forte segregação entre o mundo natural e artificial, e uma hierarquia de funções entre esses dois universos.

Bennaton [1984] ao explicar aspectos que permeiam o universo robótico em produções de ficção revela que a própria origem da palavra robô ${ }^{4}$ faz ressaltar fatos importantes que permitem entender como a questão tecnológica surge atrelada à questão do trabalho, este entendido como †агеfa, explorando, assim, sempre aspectos da vivência cotidiana em detrimento da experiência.
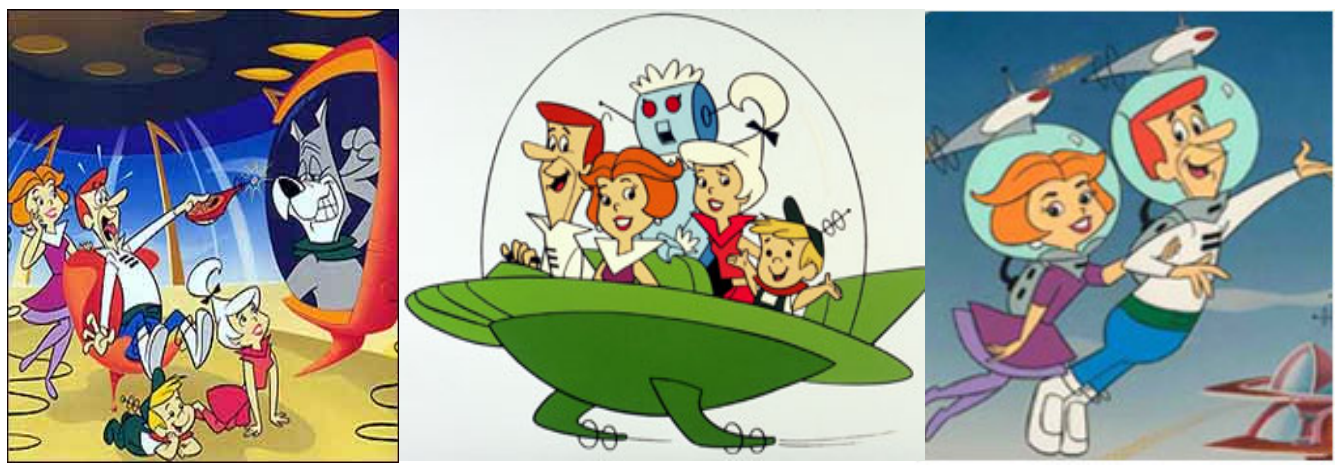

Fig. 2-4: 0 cotidiano da família Jetsons.

4 A palavra tem origem na língua tcheca e significa trabalho. Já é um indício do que se trata. Entretanto, graças aos filmes de fição científica, passou-se a consagrar robôs de forma humana: com braços e pernas, olhos, ouvidos e boca; com caráter e charme também, pois há uns que são tímidos enquanto outros são tão geniosos quanto uma criança mimada. Рor mais divertido que possa рагеcer não é bem isso. Robôs são máquinas construídas com a única finalidade de substituir a força de trabalho humano. [BENNATON, 1984, p. 22] 
De certa forma, pouco desse futuro ideal preconizado em Os Jetsons aconteceu e mostra-se bem longe de ser uma tendência contemporânea, sendo ainda hoje satirizado nos desenhos atuais. Quase que concomitante aos Jetsons a ргodutora Hanna-Вагbега ргoduzia também entre os anos de 1960 e 1966 o seriado Flintstones, que apresentava o cotidiano de uma família, também nuclear, da idade da pedra.

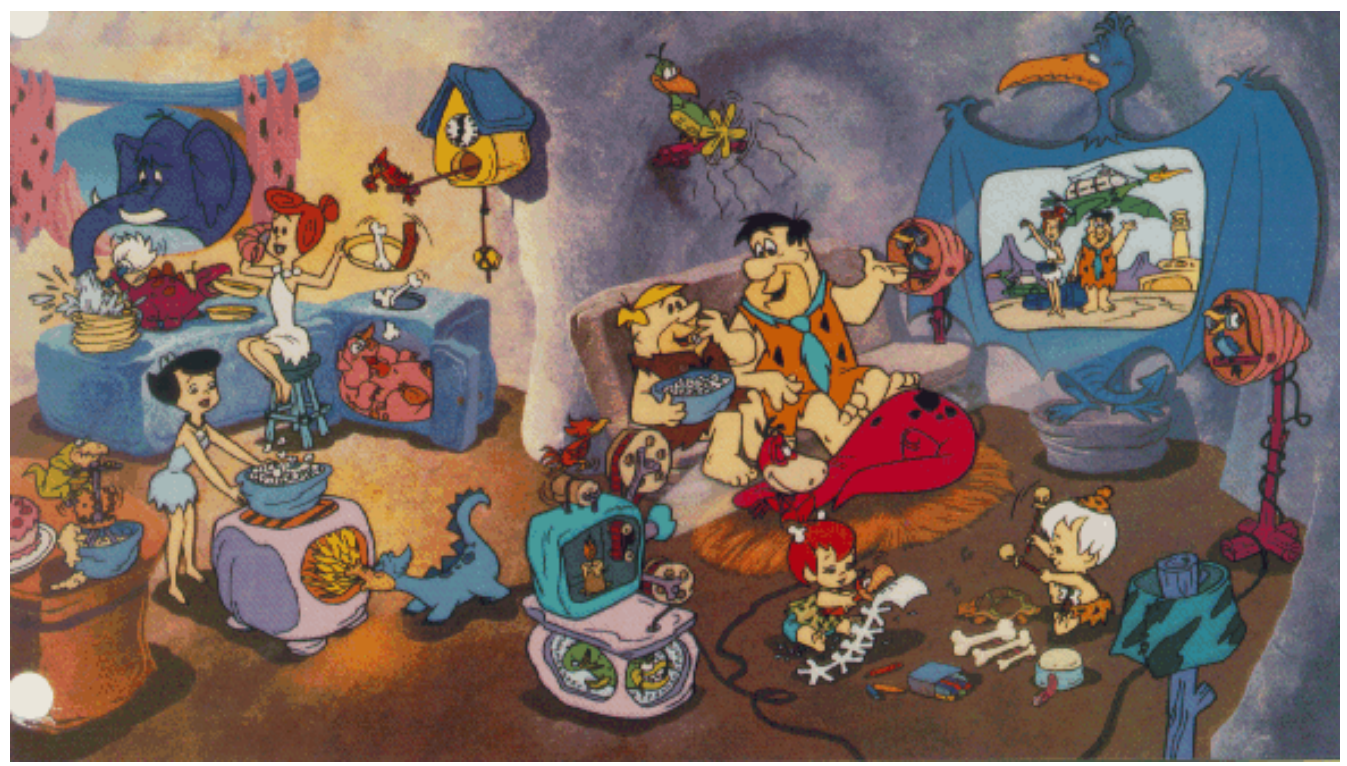

Fig. 5: Os Flintstones.

0 atraso tecnológico da época em que essa família vivia era explicitado аргеsentando objetos comuns que compõem nosso imaginário atual como se já existissem naquela época só que sem o aporte tecnológico e energético que vivenciamos hoje. Dessa forma, na animação, o cotidiano dos Flinstones é ilustrado 
рог objetos que quase sempre se apóiam na utilização de partes animais рага suprir a deficiência tecnológica: †ocadores de disco aparecem com passarinhos utilizando seus bicos como agulha, trombas de elefantes são aspiradores de pó, e o motor dos automóveis são nada mais do que os pés de seus passageiros.

É interessante pensar que, guardando as devidas ргорогсо̃es, se considerarmos aspectos do contexto contemporâneo, pela ótica da Bioengenharia e da cotejada inteligência artificial, - futuro рагеce apontar mais рага o cotidiano vivido pelos Flinstones do que рага o universo futurista ргоposto pelos Jetosns. Castells [2000] lembra que o uso de materiais biológicos na microeletrônica, apesar de ainda muito distante de uma aplicação mais genérica, encontra-se em estágio experimental desde em 1995. Еmbora a pesquisa ainda tenha um longo caminho a регсоггег rumo à integração material entre a biologia e a eletrônica, a lógica da biologia la capacidade de autogerar seqüências coerentes
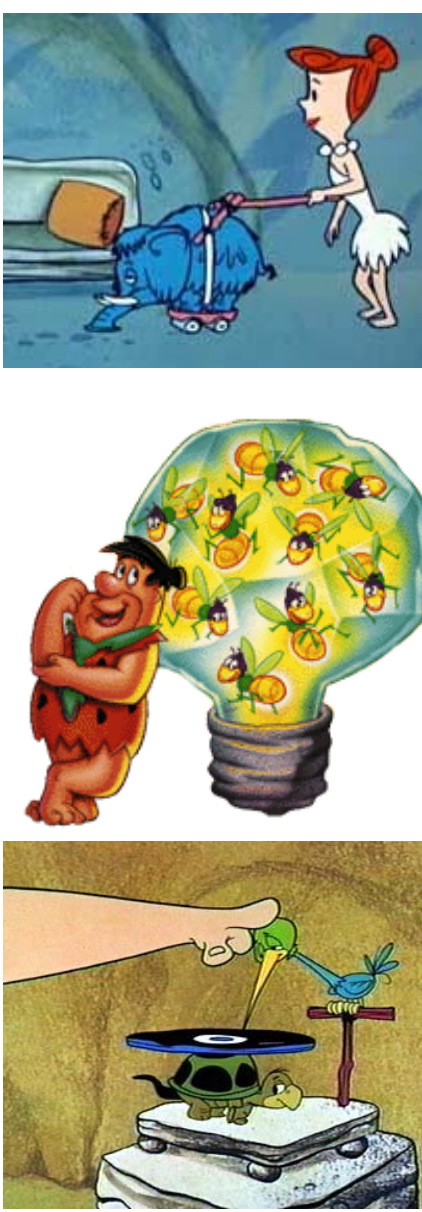

Fig. 6-8: Os objetos cotidianos da família Flintstones.

пão-ргоgramadas) está cada vez mais sendo introduzida nas máquinas. A área 
mais avançada da robótica refere-se a robôs com capacidade de aprendizagem, usando a teoria da rede neural.

(...) é necessário reconhecer que a evolução biológica humana, аgora melhor entendida em termos culturais, impõe à humanidade - a nós - a conscientização de que feгramentas e máquinas são inseparáveis da evolução da natureza humana. Também ргеcisamos регсеber que 0 desenvolvimento das máquinas, culminando com 0 computador, mostra-nos, de forma inevitável, que as mesmas teorias úteis na explicação do funcionamento de dispositivos mecânicos também têm utilidade no entendimento do animal humano - e vice-versa, pois a compreensão do cérebro humano elucida a natureza da inteligência artificial. [CASTELLS 2000, p.81]

Ргоpondo exploгаг tais conceitos, de uma maneira mais simples e inserida no cotidiano, a empresa japonesa Let's Согр, desenvolveu em 2003 um арагеlho capaz de †гаnsformar plantas em alto-falantes, fazendo com que as pétalas e folhas vibrem com as músicas. Batizada de Ka-on, que significa "som da flor", em japonês, a máquina é composta de um vaso com um ímã e uma mola, que é conectado a um aparelho de som ou TV. Basta colocar as flores no vaso, ligar o Ka-on e o imã e

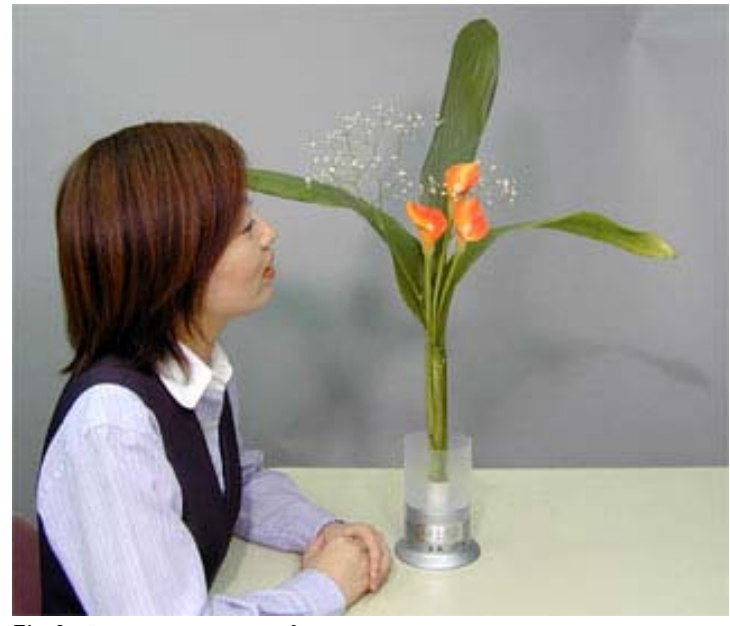

Fig.9: Foto de divulgação do Ka-on 
a mola transmitem as vibrações sonoras pelo caule das plantas. Quem se аргохimar das plantas poderá ouvir música saindo das pétalas e da folhas, que também transmitem vibrações. Além de fazer com que as plantas emitam música, ele também faz com que os insetos fiquem longe dos vasos e ainda aumenta a vida das flores. Ao contrário de alto-falantes convencionais, o Kaon faz com que o som seja disparado em todas as direções, preenchendo um ambiente inteiro com música de uma maneira mais homogênea. A еmpresa pretende lançar agora um modelo do Ka-on que poderá ser conectado a telefones permitindo que em vez de falar com um telefone, as pessoas possam falar com plantas atribuindo-se assim, uma nova dimensão simbólica ao арагеlho comunicador, subvertendo o imaginário das pessoas e criando uma nova experiência em †огno da comunicação.

\subsection{Trabalhos materiais, produtos imateriais}

0 design, como visto, cuida tanto das instâncias ligadas diretamente ao objeto a partir de um contexto imediato como também daquelas ligadas a seu ргocesso produtivo. Desta forma, nas relações de produção residem aspectos importantes a serem entendidos objetivando ргoduzir um embasamento sólido que possibilite maior ргесisão em uma leitura posterior de ргodutos do design contemporâneo. 
0 conceito de revolução tecnológica conforme foi colocado, evidencia que as alterações dela decorrentes envolvem não apenas modificações concretas no âmbito dos objetos, mas também alterações sociais que permeiam o próprio ato humano de produzi-los. Quando o homem primitivo, dominou o fogo e a arte da fundição e passou a conhecer os segredos da fabricação dos utensílios e das armas a partir dos metais encontrados em estado natural, revolucionou-se também a forma que esse próprio homem passou a olhar рага a matéria-ргima que compunha os objetos. De modo não muito diferente, o desenvolvimento das tecnologias digitais trouxe ao homem contemporâneo o desafio de re-olhar o mundo que habita, ао аргеsentar-lhe a imaterialidade como seu novo insumo de trabalho. Assim como antes, cabe-lhe a tarefa de trabalhá-lo e, ao mesmo tempo, construir novos referenciais teóricos que the dêem suporte no desafio de fundí-lo com a concretude do mundo com o qual está acostumado a lidar.

0 design surge no mundo quando o homem começa a fazer suas primeiras fегramentas, e o designer continua a lidar com ferramentas. A diferença é que sua ferramenta hoje é o рго́prio ato de gегаг informação." [AZEVEDO, 1998, p. 11]

0 entendimento das relações contemporâneas de produção surge como uma base importante na †агеfa de entender seus produtos e aspectos de suas possíveis formas de аргоргіação pelas pessoas. Рага [astells [2000] 0 capitalismo no seu modo de desenvolvimento informacional produz mudanças profundas que vão além das questões meramente técnicas e implicam numa 
геогganização das ргóprias estruturas sociais. Contemporaneamente, as relações atuais entre as formas de organização social e de produção econômica com as tecnologias de informação e comunicação surgem como grande expoente desse pensamento. 0 autor pondera que, ареsar das tecnologias de informação e comunicação não serem determinantes exclusivas das formas sociais, elas рагеcem intervir de modo decisivo nas relações tanto no âmbito individual quanto com grupos e outros elementos constitutivos de mundo.

Nessa †агеfa de tentar entender melhor tanto os produtos de design que se compõem no todo ou em parte рог conteúdos informacionais, quanto o trabalho de profissionais envolvidos na produção destes objetos, têm vindo frequentemente à tona discussões que levantam pontos importantes sobre as novas relações de produção que lidam com a informação, seja como matériaprima, seja como instrumento de trabalho. Uma delas diz respeito à †ransposição de uma produção calcada na materialidade рага uma nova ordem рrodutiva que parece pautar-se, em seus diversos âmbitos, em conceitos de imaterialidade.

Como as cidades se sustentarão economicamente dado que, de uma forma crescente, as tradicionais vantagens econômicas estarão acessíveis, "on-line", de qualquer localização virtual? [GRAHAM, 2002, p. 26] 
Segundo Graham [2002], рагесе importante геfletir sobre esse novo contexto e sobre o que acontecerá com as cidades ao passarem de uma economia internacional, baseada na produção e circulação de bens materiais, рага uma outra fundamentada cada vez mais em circulação e consumo de bens simbólicos e informacionais a partir de uma mesma base global.

0 autor аргеsenta alterações importantes trazidas para as relações de produção que surgem como resultado do advento das tecnologias de informação e comunicação. Explicita o caráter imaterial da informação que compõe tais objetos. De um modo geral é bastante comum discursos que, indo além nessa leitura, entendem como imateriais não apenas os produtos, como também os processos de trabalho que os têm como resultado. Uma análise a luz do próprio campo disciplinar do design revela que esta relação não se аргеsenta verdadeira. A importância de entender tais aspectos no dentro desta ótica, fundamenta-se numa relação existente entre tais questões e a ambivalência que o próprio termo design саггеga, conforme já colocado.

Do ponto de vista etimológico, o termo já contém nas suas origens uma ambigüidade, uma tensão dinâmica, entre um aspecto abstrato de conceber/ргojetar/atribuir e outro concreto de геgistrar/configurar/conformar." [DENIS, 2000, p. 56]

Explicitando ainda mais esse entendimento, o Dicionário Houaiss da Língua Portuguesa аргеsenta, dentre diversas outras, duas definições рага o tегmo 
design que são de suma importância para o entendimento desse pensamento que entende tanto os processos de design quanto seus produtos como entidades imateriais:

\section{Design:}

1. Concepção de um produto (máquina, utensílio, mobiliário, embalagem, publicação,etc.).

2. 0 produto desta concepção.

Assim, essa ambivalência аргеsentada pelo termo design induz a discursos acerca das relações de produção em que, com freqüência, estende as características dos produtos também aos processos de produção dos quais resulta.

É inegável o papel cada vez mais crescente das tecnologias de comunicação e informação no ргоcesso produtivo. Entretanto um †ratamento mais preciso асегса das relações inerentes ao mesmo $0^{5}$ permite entender melhor os conceitos de "ргоcessos de design" - que, ainda como no período industrial, envolvem, dentre outras coisas, o trabalho mental e braçal - e os de "produtos de design" - entendidos como as entidades resultantes desse processo.

\footnotetext{
${ }^{5}$ Ressalta-se, entretanto, que, dentro dos limites dessa pesquisa, cujo foco é o design de produtos e, mais especificamente, o design рага a experiência, apenas mencionaremos alguns aspectos das alterações no trabalho que tangenciam 0 interesse de pesquisa.
} 
0 †егmo trabalho imaterial difundiu-se a partir do trabalho de Hardt; Negri [2005] usado рага аbагсаг todo tipo de trabalho que produz um bem imaterial, como serviço, produto cultural, conhecimento ou comunicação. Hoje o termo é largamente usado, sobretudo рага se геfегіг aos diversos trabalhos cujo resultado compõe-se no todo ou em parte de aspectos virtuais e informacionais, englobando dentre outros os trabalhos de profissionais como webmasters, arquitetos e designers que lidam com ambientes e objetos ligados às questões de virtualidade. Conforme definem de maneira mais ampla os autores сгіadores do †егmo:

Forma de trabalho que cria produtos imateriais, tais como saber, informação, comunicação, relações ou ainda reações emocionais. [HARDT; NEGRI, 2005]

Essa definição se mostra duplamente interessante no âmbito do design рага experiência. Em primeiro lugar, pelo fato do grande número de propostas dentro desta sub-área do design que se apóiam nas tecnologias de informação e comunicação рага o fomento de experiências. De um modo geral, isso é feito рог meio de objetos pautados em questões informacionais e com grande potencial de comunicação. Em segundo porque o design рага a experiência envolve mais do que a concepção de um objeto concreto, explorando a produção de relações sociais contextualizadas no cotidiano a partir da аргоргіação dos objetos pelos indivíduos, culminando numa experiência emocionalmente afetiva. 
A exploração рог Hardt; Negri [2005] a cerca de novos conceitos de trabalho verificam importantes modificações ocorridas no âmbito dessas relações trazidas pelas tecnologias de informação e comunicação. Uma das leituras importantes асегса desse contexto evidencia uma possibilidade de rompimento com o modelo de trabalho que impunha a presença do trabalhador a um ambiente constituído nos moldes do ambiente fabril e que, posteriormente havia assumido a forma do escritório de trabalho.

Fluxos globais de voz, e-mail, dados, vídeo, fax e sons estão aumentando exponencialmente, fazendo com que as cidades fiquem cada vez mais atadas a extensas redes de comunicação humana, a fluxos de serviços e mídia, aos fluxos de força de trabalho baseados no 'teletrabalho', e aos fluxos de dinheiro eletrônico. [GRAHAM, 2002, p. 01]

Tramontano [1998] aо expor o pensamento de Hélène Girard, aponta alguns aspectos desta alteração que levou ao surgimento de novas formas de †rabalho. 0 autor coloca que o desenvolvimento tecnológico permitiu romper com a idéia de proximidade entre o trabalhador e o ambiente de trabalho, surgindo, assim, uma forma de teletrabalho. Isso se tornou possível como decorrência da aplicação das telecomunicações e da informática que permitiu comunicar-se à distância e intercambiar informações e dados de maneira mais eficiente. 
Percebe-se, assim, que o advento das tecnologias de informação e comunicação trouxe importantes alterações рага o âmbito do †rabalho. Ressalta-se, entretanto, que as especulações aceгca de sua imaterialidade não compõe o conjunto das †ransformações promovidas pelas tecnologias de informação e comunicação, e сагregam algumas distorções асегсa das relações produtivas. As tecnologias de informação e comunicação trouxeram a questão da imaterialidade рага diversos âmbitos da vida social, mas não é possível falarse em novas formas de trabalho, tidas como imateriais. Рага Lima [2007] a ргodução econômica capitalista atual centraliza os bens imateriais, cujo seu maior expoente é a informação, sendo esta, parte do processo de produção e, ao mesmo tempo, seu principal produto, levando a uma confusão entre estas duas instâncias e trazendo à tona posturas que entendem o trabalho como imaterial.

Um рагаlelo importante регmite entender melhor esta questão, na medida que algumas discussões surgidas no período Industrial acerca das novas relações de trabalho permanecem capazes de embasar de maneira ргеcisa a questão da materialidade do trabalho levantada atualmente sob a ótica das novas tecnologias. Dentre essas discussões, a formulada рог Кагl Магх [2006] регmanece atual até os dias de hoje e fornece instrumentos рага uma leitura que permite entender as reais alterações no âmbito das relações de trabalho na contemporaneidade. Ainda que proveniente de um contexto e de uma 
problemática bastante diversa, um ponto importante da discussão formulada рог Магх, que explicita a †гаnsposição do †гabalho concreto рага o †гаbalho abstrato, guarda grande semelhança com a discussão atual acerca da materialidade e imaterialidade do trabalho. Segnini [1984] exemplifica tal pensamento de Мarx da seguinte forma:

Se você vai para a cozinha e, com farinha, leite, ovos, fermento e manteiga faz um pão e o consome, o seu trabalho produziu um valor de uso para você e seus amigos. Foi um trabalho concreto, útil, perceptível. Рorém, quando 0 padeiro produz a mercadoria pão рага transformá-la em valor de troca e vender a sua freguesia, a força do trabalho despendida toma outras características: não é mais o trabalho útil e concreto de homens que fazem este ou aquele pão que é levado em conta! Mas é o trabalho homogêneo de todos os empregados, juntos tomados de uma forma abstrata e geral e revelado sob forma da mercadoria pão, que será considerado. [SEGNINI, 1984, p. 48]

$\mathrm{Na}$ continuidade de seu pensamento Segnini [1984] salienta que a soma dos diversos †rabalhos desprendidos рага a fabricação de um produto, que se mostra evidente quando se observa uma linha de ргodução, рог exemplo, passam a ser tomados de forma abstrata e de forma homogênea pelo sistema mercantil. Assim, quando se atribui um valor de venda ao produto, desvanecem-se os diversos trabahos que o criaram de forma a não mais se distinguir uns dos outros. 
Entretanto, Магx [2006] deixa claro que o trabalho abstrato surge como uma forma de mascaramento dos diversos trabalhos que sempre são concretos pois exigem alguma forma de esforço humano. Esse fenômeno, entendido рог esse autor como fetiche das mercadorias, e que Lukács [2003] chama de reificação, toca em um outro ponto importante nesse contexto ao explicitar que as relações sociais entre os homens surgem mascaradas por relações sociais entre coisas. Tal fenômeno parece encontrado sua expressão máxima, ainda que redesenhada рог um †гас̧o contemporâneo, no conceito de trabalho imaterial, amplamente difundido de maneira distorcida pelo discurso tecnocrata. Assim como na tеoria do fetiche das mercadorias de Магx, o †егmo †гаbalho imaterial explicita o fato de que as relações sociais de produção assumem a forma de coisas a ponto de não poderem se expressar senão a partir delas.

As modificações trazidas para o âmbito das relações de produção no tocante à imaterialidade restringem-se aos produtos ou até mesmo à parte destes. A realização de qualquer рroduto seja ele material ou imaterial envolve um intervalo de tempo e um dispêndio de força fisiológica que Marx [2006] chamou de "tempo de trabalho socialmente necessário". Dessa forma, o autor explica que todo trabalho é dispêndio de força humana sob forma especificamente adequada a um fim, e nessa qualidade de trabalho humano concreto e útil, produz valores de uso. Em consonância com tais idéias, Kurz [2000] геitera a cerca desta discussão no âmbito do cenário contemporâneo: 
Em primeiro lugar, nenhum trabalho é "imaterial", tampouco o trabalho nos setores da informação e do "conhecimento"; sempre se trata da combustão de energia humana. Imaterial é a maior parte dos produtos desse trabalho, mas justamente рог isso esses setores não podem sustentar a гергоdução social, cuja base permanece sendo o "processo de metabolismo com a natureza" (Магх) e, portanto, é material. [KURZ, 2000, p. 10]

Entender de forma precisa aspectos que compõem este pano de fundo que envolve a produção destes objetos dotados no todo ou em parte de uma carga imaterial, sob uma perspectiva da inserção ou não das tecnologias digitais, constitui um passo importante no trabalho de leitura das características destes ргóprios objetos. Nesse sentido, рагеce importante entender que as modificações †razidas pelas tecnologias de informação e comunicação рага as relações de ргodução foram muitas e que, de fato, redesenharam inclusive a instância do trabalho, mas não a ponto de entendê-lo de forma imaterial. Hardt; Negri [2005] ao discutir mais profundamente sobre tais questões retificam a amplitude do significado que tal conceito passou a abarcar, регmitindo entender de maneira ргеcisa a restrição da imaterialidade do design entendido como produto e excluindo, dessa forma, as relações envolvendo o design tido como processo de produção. 
É preciso insistir sobre o fato que a atividade implicada no trabalho imaterial permanece, ela mesma, material - ela engaja nosso corpo e nosso cérebro, como todo trabalho. 0 que é imaterial é seu produto. E, desse ponto de vista, nós admitimos que a expressão 'trabalho imaterial' é bastante ambígua. Talvez, рог isso, seja preferível falar de 'trabalho biopolítico', isto é, um trabalho que cria não somente bens materiais, mas também relações e, em última instância, a própria vida social. [HARDT; NEGRI, 2005, p. 45]

É interessante регсеber como o design рага experiência também se enquadra nessa definição na medida em que se propõe lidar com instâncias da vida social seja ampliando-as seja propiciando novas possibilidades para que ela se realize.

Sobre a questão da imaterialidade dos produtos há também ressalvas importantes a serem feitas. A luz de uma perspectiva semiológica, é possível entender que todas as coisas concretas e, portanto, materiais, carregam em si algo também imaterial. Qualquer objeto concreto (significante) pode ser enquadrado em convenções simbólicas que o fazem гергеsentar e emitir mensagens. Os signos que compõem o objeto como гергеsentação surgem como informações que por sua vez dão origem a mensagens que remetem ao lado imaterial do objeto (significado). Dessa forma, não é possível dizer que objetos produzidos sem integrar a questão da informação sob uma perspectiva tecnológico-digital sejam totalmente concretos ou que não seriam eles dotados de informação, pois todo objeto se constitui como imagem da qual emanam 
mensagens que dão forma ao seu significante, este sempre tido como imaterial. A compreensão de alguns produtos, ou de parte destes, como imateriais explicita o adensamento da informação que осогге quando os objetos são acrescidos de tecnologia digital. Dessa forma, tais objetos possuem a capacidade de computar informações baseadas na permutação de possibilidades do código binário 0/1 e, utilizando-se signos convencionados pela linguagem, estas informações são convertidas em mensagens diversas, potencializando o fluxo da comunicação. A grande dinamicidade colocada рог tais objetos reside no seu potencial de manipular os signos explorando de uma forma mais profunda aspectos da linguagem, trocando mensagens com o indivíduo e também funcionando como mediador na †roca de mensagens entre duas ou mais pessoas. Matos [2003], apoiado no entendimento do filósofo Jaques Dеггida, entende o signo como um sinal, um traço que está no lugar de uma outra coisa, a qual pode ser um objeto concreto, ou um conceito abstrato. Daí depreende-se, que os objetos, na forma de mídias digitais, ressaltam características que compõem a própria linguagem, dinamizando aspectos temporais e espaciais da comunicação, esta entendida de forma ampla, presente em qualquer forma de comportamento. 
Na linguagem filosófica de Derrida, poderíamos dizer que o signo não é uma presença, ou seja, a coisa ou o conceito não está presente no signo, é um rastro. Mas a natureza da linguagem é tal que não podemos deixar de ter a ilusão de ver o signo como uma presença, isto é, de ver no signo a presença da "coisa" ou do "conceito". É a isso que Derrida chama de metafísica da presença. [MATOS, 2003]

Santos [2006], atenta рага um fato importante acerca deste contexto que регmite entender um fenômeno reconhecido pela Psicologia como desгеferencialização do real ou des-substancialização do sujeito. Tal fenômeno tomou grande ргорогса̃o com o desenvolvimento das tecnologias de informação e comunicação e tem como característica principal a abstração total do mundo concreto, de forma que ao manipular cotidianamente mais com signos do que com objetos concretos resulta ao indivíduo um sentimento de vazio e perda de substância interior.

Na Era da Informática, que é o tratamento computadorizado do conhecimento e da informação, lidamos mais com signos do que com coisas. (...)(...) É a des-refrencialização do real e a des-substancialização do sujeito, motivadas pela saturação do cotidiano pelos signos. Seja Reagan ou o brucutu das cavernas o homem é Linguagem. Palavra, desenho, escrita, pintura, foto, imagem em movimento, são linguagens рага a comunicação, feitas com signos em códigos que, gerando mensagens, гергеsentam a realidade рага o homem. Livro, jornal, cinema, rádio e TV, são meios que vieram ampliar o público e acelerar a circulação das mensagens. [SANTOS, 2006, p.18] 
Assim, ainda que tal pensamento pareça, num ргіmeiro momento, norteado рог uma certa nostalgia рог um mundo natural que conhecemos a priori, essa ргіmeira impressão se desmitifica ao considerarmos que o fenômeno da dessubstancialização do sujeito toca num pontos que é um dos principais pilares da natureza humana: a Linguagem. Essa abordagem permite balizar a influência do universo simbólico sobre o cotidiano e induz a pensar novas formas de exploração do design a fim de ргomover novas instâncias de comunicação que considerem essa questão.

\subsection{Um novo designer}

Uma outra leitura acerca do contexto apresentado рог esta pesquisa verifica que, na medida em que a informação passa a compor o objeto sob uma perspectiva tecnológico-digital, adensam-se também relações potenciais que esse objeto e o indivíduo que dele se аргоргie pelo fenômeno da mediação podem estabelecer com o mundo. Assim, passa a ser também trabalho do designer o desenho do próprio sistema de comunicação e não apenas do invólucro concreto que as envolve e lhes fornece suporte. Cabe ao designer pensar além do concreto também o virtual e o limite de ambos, de forma que este surja mais como junção e menos como separação. 
Fugir da tendência que trabalha sobre o mundo virtual рог meio da mега †ransposição metodológica da forma como se lida com o mundo concreto ou vice-versa se mostra como um dos desafios desse novo designer na missão de redesenho do dia-a-dia. 0 caminho mais interessante рагесе ser o que busca exploгаг de forma mais ргеcisa a ampliação das relações cotidianas a partir da tecnologia de forma a produzir novas também realidades intermediárias ao concreto e ao virtual. Tal exploração só se †огna possível quando é norteada рог metodologias que não tenham como foco principal a substituição de determinadas relações com o mundo por outras se pautando no fato de estas estarem mais ou menos ligadas a aspectos tecnológicos, mas que objetive exploгаг a complementaridade do concreto e do virtual, criando realidades mescladas.

Sobre esse último aspecto que ressalta essa alteração importante das atribuições do designer contemporâneo, vale lembrar que atualmente, dada a complexidade das relações de ргodução envolvidas, гагаmente os objetos que lidam com tecnologias de informação e comunicação são concebidos por uma única pessoa, envolvendo, assim, um grupo de pessoas de diversas áreas. 
Рог ргеосираг-se, ao mesmo tempo, com o design e a implementação de sistemas computacionais interativos рага o uso humano, a produção de interfaces, assim como a pesquisa que envolve, tem na multidisciplinaridade um elemento chave, e, atualmente, ргесisa contar com pessoas cujo background é tão diverso quanto o leque de disciplinas que ele abraça. [PRATSCHKE; TRAMONTANO; MOREIRA, 2000, p. 314]

Esse fato revela uma constatação importante de que na verdade, a reformulação do design contemporâneo envolve inclusive а ргópria revisão das instituições do design e de seu programa de ensino de forma a capacitar o designer a lidar com os novos aspectos que permeiam o contexto contemporâneo da produção de objetos. Esse entendimento aponta, sem duvida, рага a inserção, nesses ргogramas, de disciplinas que lidem com a questão da informação sob uma perspectiva digital-computacional. Considerando-se uma visível reorientação de alguns institutos de design nesse sentido, ainda assim é possível dizer que o Design se encontra numa fase de transição e que tal рrofissional incumbido de cuidar de tais questões ainda não existe de forma concentrada numa única pessoa, intitulada designer.

É fácil регсеber que na сгеscente e especializada sociedade de massas, este profissional simplesmente não existe, assim como não existe curso de formação cujo formato apresente este perfil. [PRATSCHKE; TRAMONTANO; MOREIRA, 2000, p. 315] 
Frente a esse cenário, Pratschke; Тramontano; Могеiгa [2000] enxergam dois caminhos a serem seguidos no sentido de suprir essa lacuna ainda não ргеenchida рог um ргоfissional de formação mais pluгal. 0 ргіmeiro caminho, visto pelos autores como uma resposta mais simples e direta a essa situação, aponta рага a formação de equipes multidisciplinares de trabalho a exemplo do que já vem sendo feito por muitos institutos. Entretanto alguns problemas são apontados acerca dessa opção na medida em que esta colaboração envolvendo diversos ргofissionais diferentes nem sempre se аргеsenta fácil como se possa рагесег num ргіmeiro momento. Sempre caberá a um profissional em específico a coordenação do trabaho e, em uma área tão nova quanto imprecisa, caberá pensar então qual será o profissional mais capacitado a essa função. Um segundo caminho, mais trabalhoso e de implementação bem mais longa, seria a revisão da formação dos designers atuais, capacitando-os tanto рага lidar com as novas questões tecnológicas de maneira autônoma, quanto рага gегеnciar o trabaho de um grupo de ргоfissionais de áreas diversas, ргomovendo uma maior integração do trabaho. Frente a essas opções, o que fica constatado de maneira evidente é a necessidade de um novo aporte de profissionais capazes de lidar com a questão tecnológica contemporânea de modo menos estanque no cotidiano. Explorar a linha contrária que se expressa рог uma mега automação das atividades e o conseqüente aniquilamento de algumas relações sociais рагесе ser o grande desafio desse novo profissional. Assim como, геvег as implicações espaciais e temporais colocadas pela 
sociedade tecnológica atual, explorando o analógico e o digital, o concreto e o virtual, o original e o simulado, não como entidades opostas, mas sim complementares, assumindo-se assim, a diversidade de relações que permeiam o contexto contemporâneo atual e, ao mesmo tempo, conferindo-lhe a unidade que рагесе almejar. 


\section{CAPÍTULO 2}

Design рага а experiência 

"Imaginemos uma fabulazinha onde o herói seja um certo urbanóide pósmoderno: você. Ao acordá-lo, o rádio relógio digital dispara informações sobre o tempo e o trânsito. Ligando a FM, lá está o U-2. 0 vibromassageador amacia-lhe a nuca, enquanto o forno microondas descongela um sanduíche natural. No seu micro Aple II, sua agenda indica: REUNIÃO AGÊECIA 10HI TÊNIS CLUBE 12HI ALMOÇOI TROCAR CARTÃO MAGNÉTICO BANCOI TRABALHAR 15HI PSICOTERAPIA 18HI SHOPPINGI OPÇÕES: INDIANA JONES - BLADE RUNNER DVD ROSE, SE LIGARI SE NÃO LIGAR, OPCOOES: LER O NOME DA ROSA (ECO) - DALLAS NA TV - DORMIR COM SONIFEROS VITAMINADOS/.

Rose ligou. Você embarcou no filme Indiana Jones sentado numa poltrona estilo Menphis - uma pirâmide laranja em vinil - desfiando piadas sobre a tese dela em filosofia: Em Cena a Decadência. A Câmara adaptada ao vídeo filmou vocês enquanto faziam amor. Será o pornô que animará a próxima vez.

Ao trazê-lo de carro para casa, Rose, que esticaria até uma festa, veio tipo impacto: maquiagem teatral, brincos enormes e uma gravata preateada sobre o camisão lilás. Na cama, um sentimento de vazio e irrealidade se instala em você. Sua vida se fragmenta desordenadamente em imagens, dígitos, signos - tudo leve e sem substância como um fantasma. Nenhuma revolta. Entre a apatia e a satisfação, você dorme.

[SANTOS, 2006, p. 8-9] 


\subsection{A proposta}

0 conceito de Consumer-led design ${ }^{6}$ геfere-se às propostas que buscam atribuir ao usuário o poder de influenciar ou, até mesmo, de determinar o design do produto. Com uma proposta similar, mas resguardando a total autonomia do designer, o design рага a experiência propõe uma participação menos passiva e maior liberdade do indivíduo frente às possibilidades dadas pelo objeto. Nessa postura conceptiva, a relação com o objeto é pensada de forma a fomentar experiências no cotidiano. A interação surge como elemento essencial a ser explorado pelo ргоjeto, constituindo-se como um catalisador nas relações entre objeto e indivíduo.

Não se trata mais de uma questão de permitir ao usuário construir variações previsíveis a partir de elementos simplificados, mas, antes, de gегаг um ргоjeto com densidade conceitual de forma que permita desdobrar, ou mesmo desconstruir, as funções do objeto. [DENIS, 2000, p. 185]

Nessa linha de produção que visa uma interação maior com o objeto e que culmina na experiência do indivíduo, Denis [2000] aponta o trabalho do designer Philippe Starck como um dos grandes proponentes do design como processo de interação. Como exemplo importante que explora esse conceito o projeto do designer francês рага uma série de bancos de praça projetado para o Parc de

\footnotetext{
${ }^{6}$ Em português: Design conduzido pelo consumidor.
} 
la Villette, em Paris, abre ao usuário a possibilidade de alterar a posição do assento e, dessa forma, interagir tanto com a peça quanto com outras pessoas ou o espaço. Apesar dos bancos serem fixos, sua base movimenta-se formando diversos ângulos, permite que duas pessoas sentadas lado a lado se afastem ou se aproximem, ou ainda que se mude de posição para acompanhar o sol ou a sombra, sem sair do lugar.

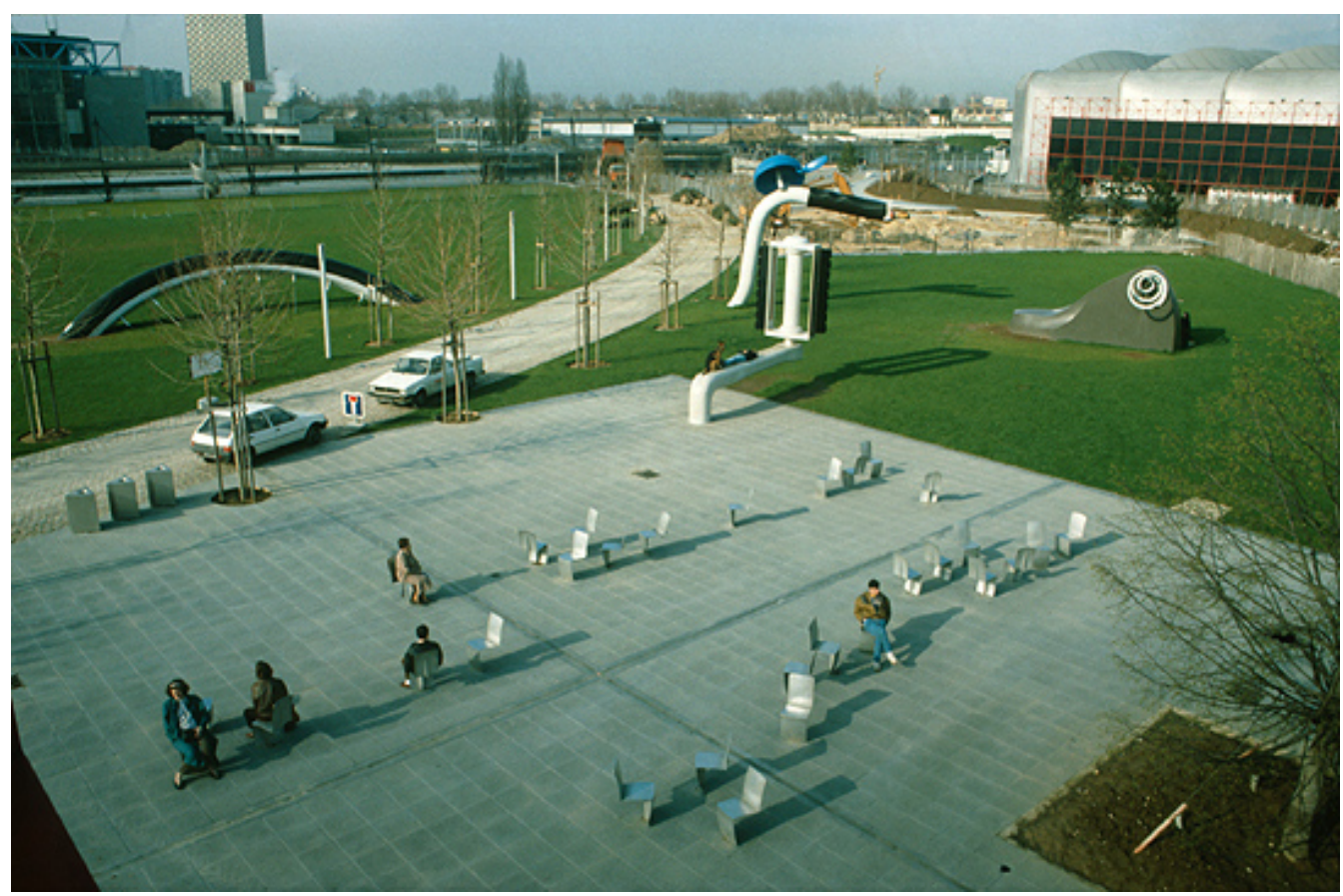

Fig. 10: Bancos projetados por Philippe Starck рага o Parc de la Villette em Рaris. 
Ainda que esta não seja uma proposta declarada de Starck, sua forma de conceber os objetos aponta рага a exploração de novas experiências em †огno do uso, conforme explica Denis [2000]:

\begin{abstract}
Рara ele o objeto deve ser encarado pelo designer não simplesmente como um produto, mas como uma instância de tomada de consciência de uma experiência de uso. Рara seus críticos, os objetos projetados por Starck são pouco funcionais, mas ele certamente rebateria que todo objeto exerce bem mais do que uma única função. [DENIS, 2000, p. 188]
\end{abstract}

Explicitando ainda mais a questão da interação como forma de fomentar experiências, o objeto entitulado Come a Little Closer projetado pela designer Nina Farkache, explora a mesma temática propondo um banco composto por uma superfície de esferas na qual os assentos na forma de pratos, totalmente desconectados dessa superfície, deslizam sem muito controle рог parte do usuário, propondo também uma aproximação e afastamento entre as pessoas, inclusive de forma involuntária. Tal proposta explora o tema do descanso no ato de sentar-

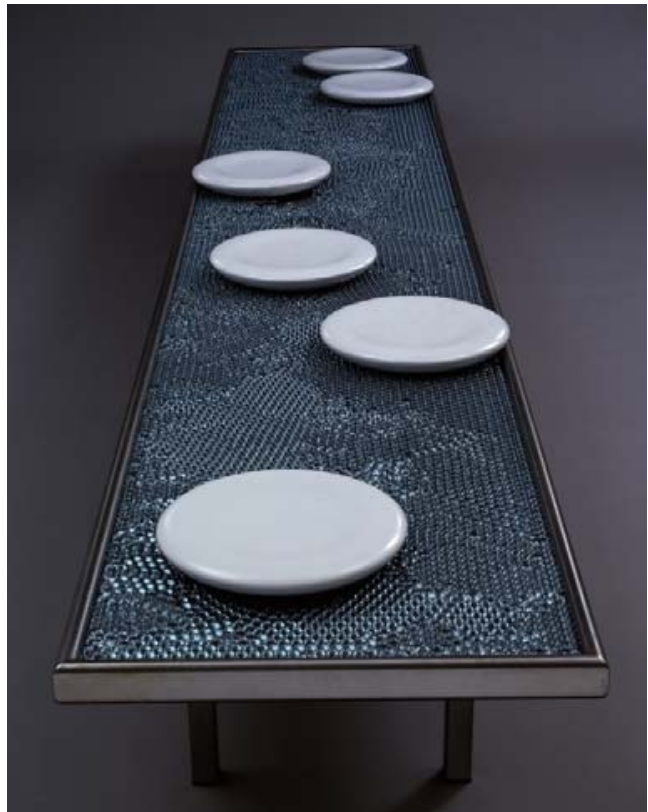

Fig. 11: Banco Intitulado Come a Little Closer ргоjetado рог Nina Farkache. 
se, subvertendo alguns conceitos que o envolvem como a questão do isolamento entre as pessoas e da estabilidade e conforto. Numa análise preliminar pode-se identificar alguns problemas funcionais em torno desse uso. Entretanto, essa não é a questão principal рага a designer, assim como рага o design рага a experiência, cujo próprio nome explicita qual deve ser a ргopriedade principal do objeto. Cabe-se falar assim, não em usos, porque estes ligam-se sempre com as questões de funcionalidade do objeto, mas sim em formas de apropriação, incluindo dentre estas, sobretudo as pouco funcionais рог геlacionarem menos com a atividade de †агеfa e da vivência e possibilitarem uma maior liberdade de еmergirem experiências.

No mapeamento de algumas dessas tendências contemporâneas de maneiras conceber, o Design рага a Experiência emerge, assim, propondo uma nova abordagem de envolvimento com o objeto. Abrange um agrupamento de trabalhos embasados em conceitos e práticas bastante próximos que buscam explorar de diversas maneiras o fomento de experiências a partir dos produtos desse design. Dentre outras problemáticas, o design рага a experiência toma como objeto de intervenção o cotidiano desprovido de reflexão e limitado por um utilitarismo imposto por objetos resultantes de processos de concepção pautados prioritariamente em conceitos tradicionais como eficiência, rapidez, economia e funcionalidade. A maneira como o design é atualmente concebido, ditada sobretudo рог questões técnicas e de mercado, 
preenche o espaço habitacional com objetos que se impõem no ambiente doméstico de modo austero e como única forma de apoio às relações interpessoais e espaciais que emergem no dia-a-dia. Tais objetos derivam da ргoposta simplista de otimizar as atividades domésticas ao máximo e maquiar o ambiente no qual se realizam, tornado-as assim, menos pesarosas. 0 cotidiano é visto essencialmente como um conjunto de tarefas a serem cumpridas, retirando-lhe o imprevisto e a espontaneidade e fazendo com que o design intervenha sobre ele limitando-se apenas a desenhá-lo como vivência.

Nesse ponto, reside uma questão chave рага o design contemporâneo. Identifica-se nessa limitação o esmaecimento de algumas relações do cotidiano, fazendo com que este passe a construir-se recortado e empobrecido. Ao mesmo tempo em que emergem no espaço doméstico dando forma ao dia-a-dia, ao pautarem-se sempre em quesitos funcionais, tais objetos esvaziam-no de aspectos importantes do cotidiano, banalizando as experiências sufocadas pela roterização de tarefas que the são impostas. Assim, o design рага a experiência propõe questionar o funcionalismo como vertente norteadora absoluta na concepção de objetos, rompendo com o modelo de cotidiano limitador e desenhando-o рага além da vivência, рог meio do fomento e da exploração de experiências. 


\subsection{Diálogos com a Pós-modernidade: A origem de alguns conceitos}

Romper com o enraizado modelo de concepcão de objetos pautado em questões funcionais e ao mesmo tempo ргорог uma relação mais profunda com os objetos não é †агеfa fácil. Tampouco o é, identificar com precisão em que momento da história do design surge essa preocupação em romper com a funcionalidade e rigidez simbólica para focar-se mais na questão da experiência. É possível, no entanto, situar alguns conceitos norteadores do design рага a experiência, sobretudo os que the dão um desenho bemhumorado, questionando a funcionalismo e a austeridade dos objetos, dentro de uma tendência tipicamente pós-moderna, que, propondo o que o pósmodernismo chama de anti-arte, critica a estetização do cotidiano promovida pelo design. A idéia de pós-modernidade surge nas décadas de 1950 e 1960 sob influência do Dadaísmo que explorava o conceito de nonsense e principalmente do Pop Art que tenta resgatar a função da arte como participante do dia-adia do ser humano, dando significado à existência humana contemporânea. 0 movimento pós-modernista traz à tona questionamentos acerca do "velho" e do "novo", do presente e do passado, opondo-se ao moderno e buscando геtirar deste, algo novo. 
"0 design assume uma função oposta ao funcional, lança-se à ргосura de uma nova estética bem-humorada que denominou de não-estética. Torna-se importante a relação entre o designer e o passado, o design moderno e o pósmoderno, tendo dentro de cada um, através dos objetos, um verdadeiro contraste entre o que já foi e o que virá. Os designers começam então a domesticar os objetos, que são produzidos como alegorias, alguns levando até objetos eletrônicos com luz e neon." [AZEVED0, 1998, p. 23]

Assim, tal postura surge com o intuito de valorizar a importância da nãofuncionalidade como uma forma de еxpressão, explorando humor e ігоnia nos objetos, muitas vezes subvertendo os seus usos como ргорõe o design рага а experiência atualmente. Na mesma linha, o uso de luzes e neon, uma das outras marcas do design pós-moderno, mostra uma ргеocupação em explorar mais os sentidos, além de apontar os primeiros traços de uma exploração da tecnologia sob uma outra perspectiva, agregando novos significados simbólicos aos objetos.

Atualmente, a oposição entre velho e novo assumiu também uma forma bastante peculiar. Soma-se assim uma postura que, ao mesmo tempo em que se pauta na exploração das tecnologias de informação e comunicação, explora a convencionalidade da forma dos objetos, ressaltando-a quase como no desenho de um ícone рага геferenciar-se a uma outra época e a um outro contexto tecnológico. A forma iconográfica do objeto é usada рага геforçar a referencia ao passado, explicitando o contraponto com uma outra 
temporalidade гергеsentada pelos novos atributos simbólicos que o objeto agrega e que remete às novas tecnologias e por extensão ao tempo atual que vivemos. Em meio a esse contexto, a escrivaninha com seu desenho à moda de Luiz XV surge, por exemplo, com uma tela touch scren por meio da qual se pode interagir com o mobiliário, redesenhando novos usos e explicitando as novas relações de аргоргiação que podem surgir com simples exploração da tecnologia digital, ainda que a forma concreta do objeto surja temporalmente descontextualizada, sendo inclusive caricaturizada рага геssaltar essa impressão.

0 objeto 22 Pop desenvolvido pelo Instituto Ivrea, propõe uma reflexão semelhante a partir da ironia e explicita o contraste entre passado e futuro, como visto, marca registrada do design pósmoderno. Esse objeto constitui-se basicamente numa máquina de escrever Olivetti "Lettera 22" - o primeiro modelo de máquina de escrever, ргoduzido em 1950 adaptada com circuitos eletrônicos

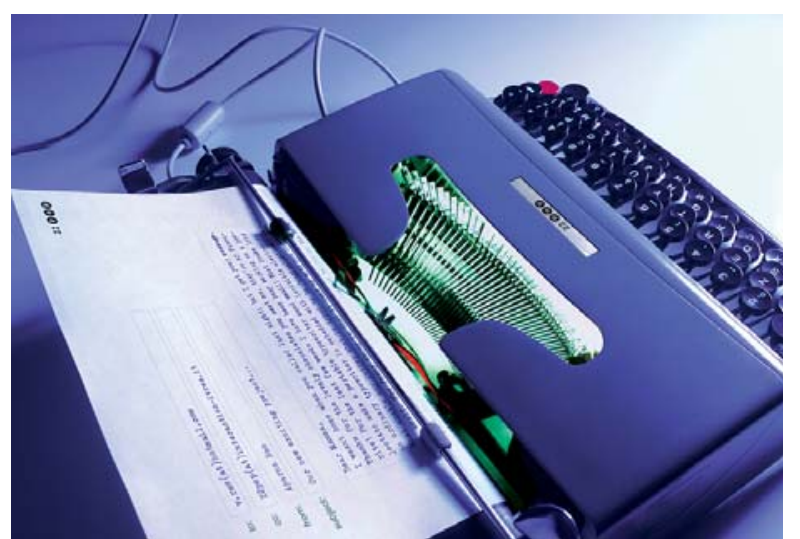

Fig. 12: 22 Pop. Designers: Britta Boland, Mario Mattioda, Esther Mildenberger, Phil Tabor

рага tег a capacidade de digitalizar os textos que nela são datilografados e enviá-los via e-mail. Deixando de lado as críticas possíveis a uma formulação um tanto 
simplista, sobretudo pelo objeto se ргорог a inserir uma política digital entre pessoas mais idosas que têm dificuldade a adaptar-se ao uso do computador, esse objeto permite uma leitura interessante e bastante pertinente ao contexto colocado. Caminha, assim, no sentido de explicitar е ргomover uma reflexão a partir da exposição ao contraste tecnológico-temporal e evidencia um certo avanço alcançado pelo pensamento pós-moderno que visa explorar o contexto formal do objeto рага além da ótica estético-funcionalista. De um modo geral, esse pensamento evidencia alguns aspectos que marcam uma certa crise e conseqüente reposicionamento frente a um novo cenário promovido sobretudo no âmbito do design e da агquitetura. Nesse contexto, рагесе importante compreender que a questão formal não é o que está em jogo na contemporaneidade, sobretudo porque as relações entre os indivíduos e as coisas alcançaram uma instância maior com o desenvolvimento das tecnologias de informação e comunicação.

Segundo Azevedo [1998] o trabalho dos grupos italianos Archizoom (1966), Alchimia (1976) e Memphis (1981) podem ser entendidos como os primeiros a ргoduzirem objetos de design deliberadamente pós-modernos e seu embasamento conceitual surge também

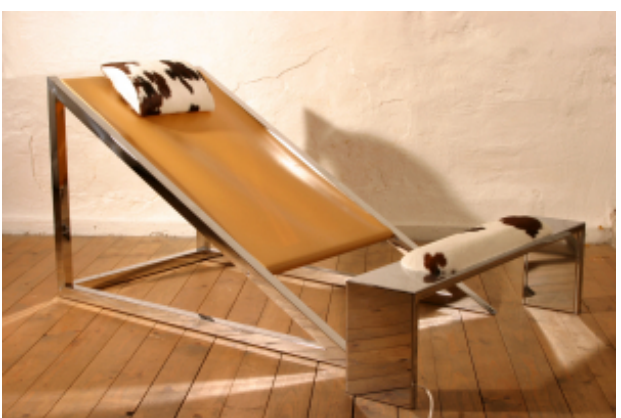

Fig. 13: Poltrona elástica Mies (1969). Archizoom 
com grande relevância no trabalho de entender os primeiros passos que levaram à formulação teórica que embasa o design рага а experiência. 0 †rabalho do Archizoom surge sobretudo como crítica ao funcionalismo pela sua cumplicidade com 0 sistema de produção.

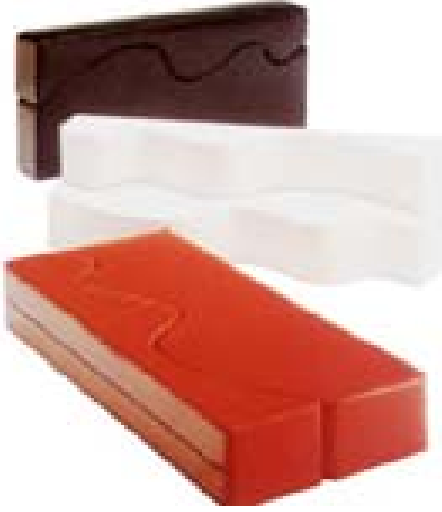

Fig. 14: Assento Superonda (1966). Archizoom

0 grupo Alchimia pretendia no seu ргograma afirmar-se como um fórum pósradical fórum de discussão. Em vez de se concentrarem num design voltado рага a produção em massa ou sobre a utilidade dos objetos, eles voltavam-se para uma postura mais expressiva, imaginativa, poética e рага uma atitude projetual irônica.

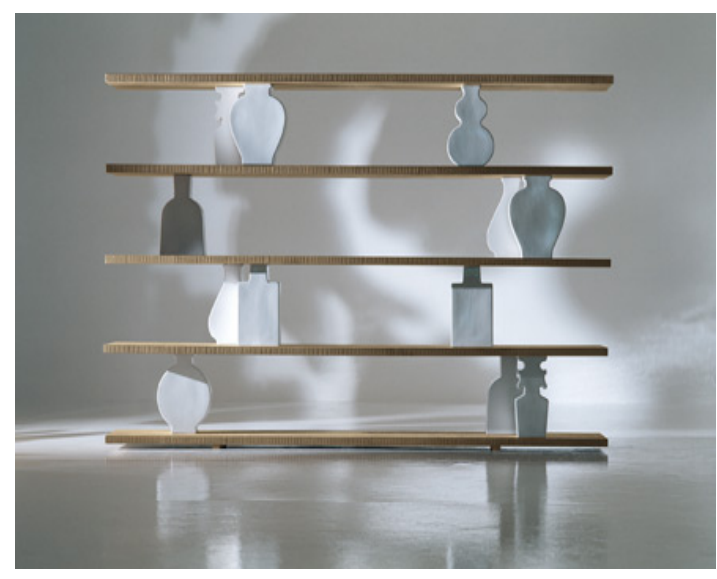

Fig. 15: 0 anti-design do grupo Alchimia.

Destaca-se, nesses grupos, o trabalho de Ettore Sottsass e Alessandro Mendini, integrantes do Memphis, sobretudo рог explorarem, já naquela época, 
a subversão dos objetos a exemplo do que fazem atualmente algumas propostas do design para a experiência. Sottass empenhava-se no campo da exploração projetual e desenvolveu pesquisas que subverteram o relacionamento tradicional dos móveis que iriam ocupar o espaço de uma casa. Os objetos рог ele criados continham características bastante peculiares. Ao invés de ргорог um objeto altamente figurativo com funções autônomas, ele promove um novo tipo de comportamento para o móvel residencial. Рara Sottsass não está em discussão o

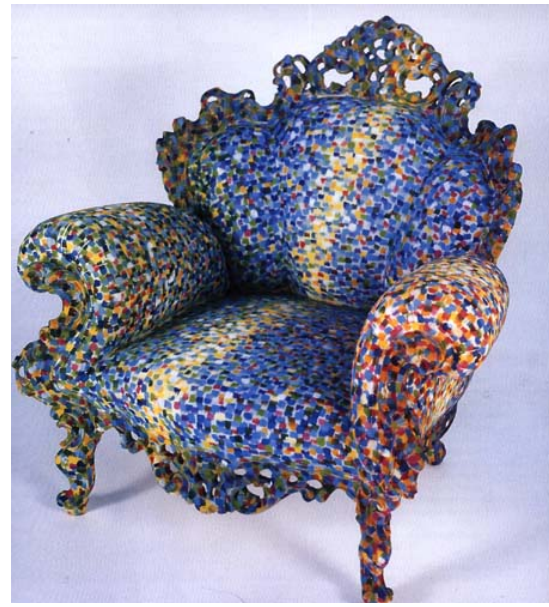

Fig.16: A Poltrona Di Proust promove uma sobreposição do tempo ao contrapor a forma do objeto a suas cores impressionistas (1978).

Alessandro Medini conforto. 0 valor emocional em relação ao objeto não é dado рог meio de sua funcionalidade, mas por seu nível de expressividade.

Рага Santos [2006] os objetos do Memphis inauguram alguns conceitos importantes рог passarem a levar em conta certos princípios pouco comuns рага a época como cheiro e tatilidade. São responsáveis рог аbгіг uma vertente pioneira na história do mobiliário e da

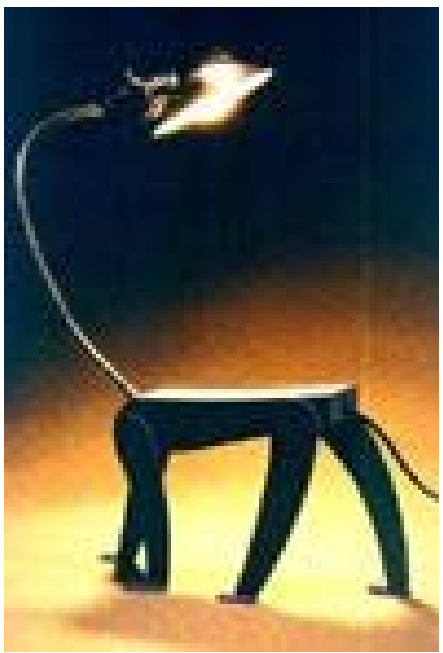

Fig. 16: A luminária projetada em 1987 рог Umeda (Memphis) ironiza a forma dos objetos. 
decoração. Os objetos assumem uma dimensão perceptiva maior, permitindo realmente um envolvimento espacial. Ao explorarem esses quesitos como atributos dos objetos o que se verifica é nada menos que uma intenção de envolver o indivíduo por meio da exploração de seus sentidos propiciando-lhe uma outra experiência com o objeto. Além disso, essa postura revela uma crítica à sacralidade da forma e imagem do objeto, produto do design de cunho meramente esteticista, sempre pautado no uso do estimulo visual como principal forma de contato com 0 indivíduo, negando-lhe suas outras capacidades sensitivas.

0 Studio Menphis talvez seja o que mais tenha aberto os caminhos nas décadas de

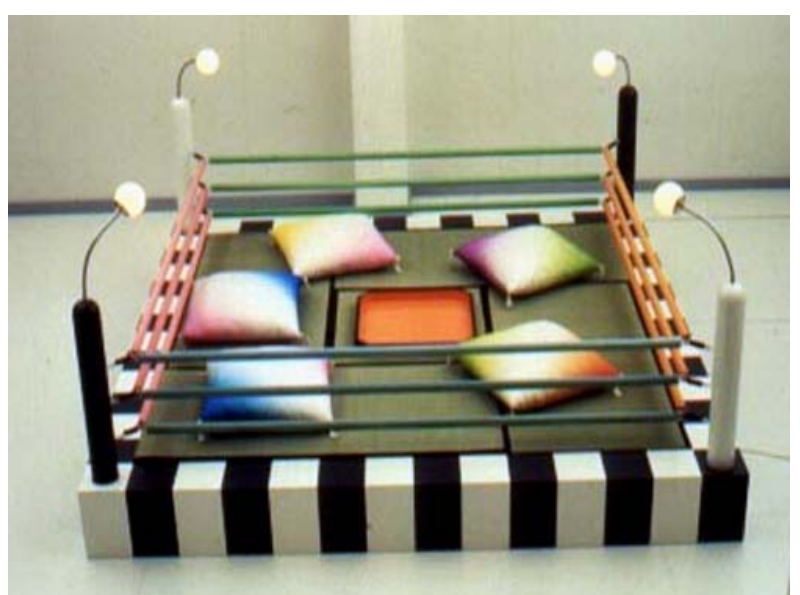

Fig. 17: Mobiliário de descanso em forma de ringue. Memphis

1970 e 1980 рага que, hoje se possa falar em design рага а experiência.

Entretanto, рага que fosse possível se colocar como um grupo deliberadamente criativo e estimulante da imaginação, ele teve que se expor e experimentar рог meio de um design eclético, гоmper o dogma vigente que delimitava a fronteira entre o bom e o mau gosto. Sua produção, auto- 
intitulada "gíria suburbana", рог questionar o design institucional, é marcada рог móveis com desenhos fantasiosos e revestimentos em cores bеггantes, forгados com plástico estampado cujos padrões são desenvolvidos pela ргópria escola. Portas a quatro cores se abrem рага camas em forma de ringue, esculturas de neon piscam sobre poltronas cônicas pintadas como onça. Alguns de seus objetos егаm quase inutilitários. Explorava ao máximo à linguagem sendo decorados com lâmpadas coloridas e confrontadas com materiais como mármore, bronze, madeira, metal, vidro e alumínio. Mais do que questionar modelos vigentes, sua produção assume um papel utópico da utilidade, †огnando seus móveis um

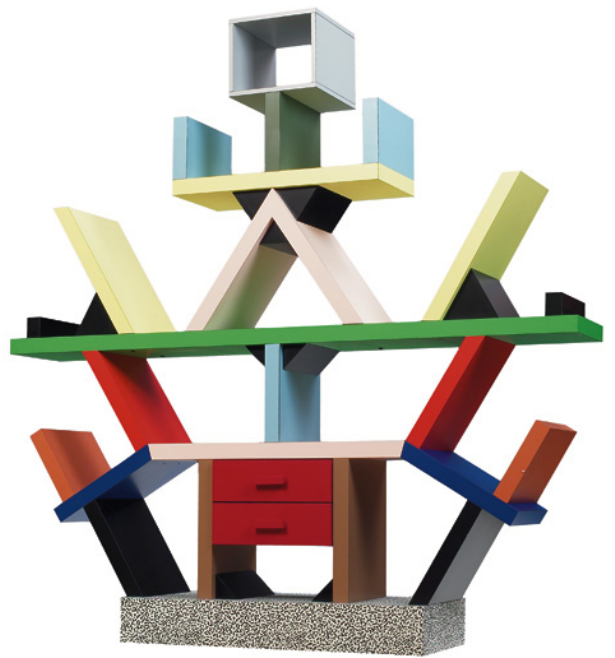

Fig. 18: Estante Carlton Sotssass (Memphis)

verdadeiro play-ground opcional.

Assim como quase tudo no movimento pós-moderno a ironia não falta também ao grupo Memphis. Todos os seus móveis têm nome de hotel e, na estante Carlton, ргоjetada рог Sottsass, as ргаteleiras assumem linhas diagonais e os livros ficam todos inclinados, já que se acredita ser esse o desejo original dos mesmos. Atribui-se, assim, uma dimensão esquizofrênica ao objeto tomando como critério os supostos desejos das coisas e não das pessoas para formular 
tal proposição. Ao mesmo tempo, joga com o imaginário humano acerca da gravidade e do efeito psicológico que as linhas de força inclinadas exercem quando associadas a um objeto cuja situação convencional é o equilíbrio e a estabilidade como, tradicionalmente, ocorre em uma estante de livros comum. Por meio de propostas deste tipo o chamado anti-design italiano escarnecia do paradigma funcionalista, contribuindo рага uma crise do funcionalismo desde então percebida. Os valores estéticos, lúdicos e poéticos do design exaltavam maior importância e o design passa a ser pensado como uma obra aberta. Na poltrona

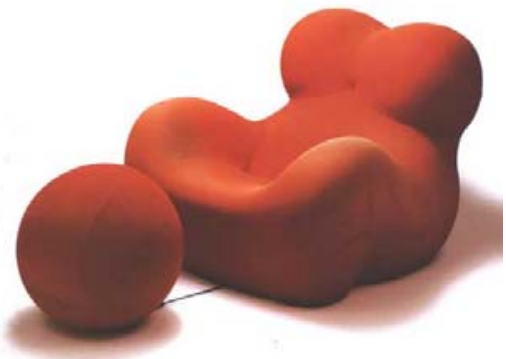

Fig. 19: Poltrona e otomana (1969). Gaetano Pesce.

de Pesce, que assume a forma de uma mulher sentada, o valor simbólico гесupera um primado provocador: o que se vê já não é apenas a dimensão utilitária do objeto, mas a auto-expressão, o humor que está na base do design anti-design. Assim, a anti-arte pós-moderna impunha-se com a ргоposta пão de гергеsentar como queria o Realismo, nem de interргеtar como se propunha o Modernismo, mas sim apresentar a vida diretamente em seus objetos, encontrando grande consonância com a postura contemporânea colocada pelo design para a experiência.

Assim, como os modernistas sempre pregavam religiosamente a funcionalidade рог levar a arte e o cotidiano demasiadamente a sério, o movimento pós- 
moderno pegou a contramão e propôs-se fazer uma nova intervenção estética, utilizando-se das formas banais e vulgares рага ргоmoverem um rompimento radical da lógica "forma e função". Entretanto, ao mesmo tempo em que esse rompimento abriu brechas admitindo projetos experimentais que a austeridade e o гіgor metódico-ргofissional moderno jamais tегіa регmitido, a ігоnia talvez demasiadamente exagerada que os pós-modernistas carregavam рагеcia indicar que eles estavam mais ргеocupados na verdade em гіг levianamente de tudo que já fora feito do que em resgatar algo de social que havia sido esquecido. Talvez o design para a experiência possa ser entendido como a mediana entre estas duas coisas. Ele emerge na contemporaneidade com a ргоposta de сгіar, ao mesmo tempo com rigor e uma espontaneidade peculiar e bem-humorada, novos conceitos de design capazes de valorizar um desenho menos utilitário, entendendo que este guarda instâncias da vida social que o homem desconhece, ou que há muito tempo ficaram рага trás.

\subsection{O papel do indivíduo, do designer e do objeto dentro do sistema que leva à experiência.}

0 design рага a experiência atua sobre o cotidiano, englobando os aspectos culturais e contextuais que envolvem os indivíduos e suas formas de relacionar-se com os objetos. Estes últimos são entendidos como o ponto de partida para a construção de um conjunto de relações que dão forma a um 
sistema social no qual experiências podem emergir a todo o momento. Não se †rata de enxergar os objetos como instrumentos facilitadores na execução das †arefas do dia-a-dia, mas pensar as relações entre objetos e indivíduos de maneira mais ampla para além da questão do uso, cuidando de outras instâncias e formas de apropriação possíveis.

Рага Littlejohn [1982], o †егmo sistema геfеге-se a um conjunto de objetos ou entidades que se inter-relacionam formando um todo. Partindo de tal definição, os objetos resultantes do design para a experiência surgem também como partes de um sistema cujo papel é ргоmover e ampliar instâncias sociais do cotidiano. Bennaton [1984], a partir de uma análise cibernética, ргорõe uma complementação acerca do conceito de sistema que permite entender aspectos importantes das entidades envolvidas no processo que leva a uma experiência:

\footnotetext{
A proposta, em resumo, é que não pensemos mais fenômenos como o lugar onde se identificam uma única causa ou efeito. Em lugar disto, que se eleja como objeto de investigação todo o conjunto de fatos que, de um modo ou de outro, se achem presumivelmente ligados. Da correta análise desta totalidade resultará a compreensão do fenômeno. A teoria geral dos sistemas mostra que, mesmo sendo de grande porte - sistemas com múltiplas e interdependentes variáveis - eles podem ser согretamente investigados. [BENNATON, 1984, p. 26]
} 
Dentro deste contexto, Manzini; Meroni [2005] ressaltam que ргоjetar a experiência significa projetar uma situação, de forma não apenas a estabelecer os limites no qual a experiência se realiza como também objetivando fomentar sua realização.

\footnotetext{
Ргоjetar uma experiência significa portanto ргojetar-lhe as situações, ргedispor-lhe as condições. Não se trata assim, de ргоjetar apenas objeto, um lugar ou um serviço, mas, juntamente com estes, um contexto ambiental e cultural definido. [MANZINI; MERONI, 2005]
}

Os autores complementam ainda que a experiência não é um fato de rotina e tem сага́ter †ransformador numa dada situação, sendo sempre um fato extremamente pessoal e, portanto, não-programável. Entretanto, é possível predispor-the as condições de modo que ela se realize. Рor isso é mais соггеto falar-se em design рага a experiência ao invés de design da experiência.

No desenho das formas possíveis de apropriação de um objeto, foca-se no contexto social e ambiental que este ocupa, ргopondo-se ргojetá-lo e melhorálo, com uma particular atenção рага um aspecto que Manzini; Meroni, [2005] chamam de co-envolvimento afetivo. Dessa forma, tal †еогia induz a considerar o inteiro contexto no qual se dá a relação com o objeto como um elemento fundamental para um total envolvimento, fomentando-se assim, a experiência. 
Diferentemente de outros processos de design cujo foco de projeto gira em †огno do objeto, pensar o design para a experiência significa pensar o todo que compõe o sistema que culmina na experiência no qual os objetos e o сагáter mediador e de interação que possuem são apenas alguns aspectos a serem ргоjetados pelo designer.

objeto comestível
Oranienbaum candy
desenhado pelo designer
Martí Quixé, assim como
as relações de co-
envolvimento que ele
propõe com o mesmo,
explicitam bem algumas
dessas questões que

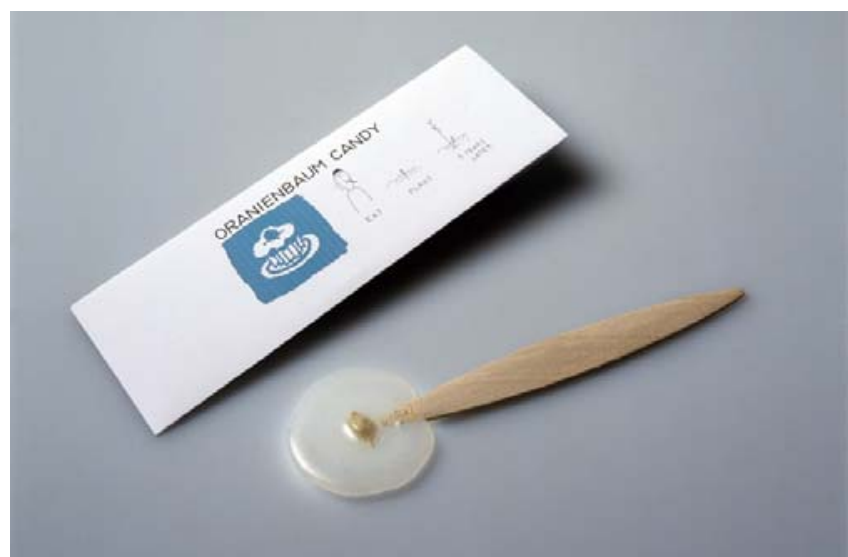

Fig. 20: Oranienbaum Candy

Martí Quixé

рermeiam o âmbito das experiências em design. Uma das leituras possíveis em †огno das relações aí desenhadas leva-nos a verificar como o objeto é composto dentro de uma ótica que considera tanto o todo, como as partes que o compõem. As relações de interação entre essas partes e a forma como 0 indivíduo poderá interagir com elas, construindo a partir desse conjunto de fatores uma narrativa pessoal, também são elementos projetados. Assim, toda a experiência concebida pelo designer gira em torno desse objeto de 
composição bastante simples. O Oranienbaum Candy guarda no centro uma semente e se prende a uma haste que the facilita o manuseio, conferindo-lhe a aparência de um pirulito comum. Assim, ao comer o doce a semente que resta induz ao seu plantio e o ato de consumir passa a estar ligado com a idéia de fazer surgir, ao invés de eliminar ou destruir, subvertendo a idéia de consumo. No final, sugere-se na embalagem que se use a haste рага marcar o lugar do plantio e геforçar a dimensão simbólica da паггativa a partir da construção de marcos e referências concretas de lembranças. A leitura sob uma ótica ambiental acerca do consumo também é possível. 0 fato é que, pautando-se em tais conceitos para conceber os objetos, lidando com as formas de аргоргіação de maneira mais ampla, o designer está projetando uma experiência, sobre a qual cada indivíduo sempre construirá uma паггativa diferente.

0 гесurso гесогrente no âmbito do design рага a experiência que confere ao indivíduo grande poder de intervenção, induz muitas vezes a pensá-lo como co-autor no ргоcesso de design. Entretanto, esse entendimento não рагесе correto numa análise mais profunda acerca de tais relações. A luminária Do Scratch, também do designer Marti Quixé, é outro bom exemplo elucidador dessas questões. Basicamente, esse objeto se constitui em uma caixa coberta рог um tipo de resina preta e guarda no seu interior uma lâmpada. Рara que o objeto passe a funcionar como luminária é ргеciso que essa resina seja 
raspada, геtirando-lhe a opacidade em alguns pontos e permitindo assim que a luz emitida pela lâmpada alojada no interior da caixa consiga iluminar o ambiente externo atravessando os pontos em que a resina foi removida. A liberdade de intervenção sobre o objeto é bastante ampla, pois a resina pode ser raspada formando qualquer palavra, desenho ou sinal, atribuindo uma outra dimensão simbólica ao objeto e conferindolhe 0 poder de emitir outras mensagens que fogem ao domínio do designer. Ao indivíduo cabe também refletir sobre a escolha de гаspar ou não a luminária e como fazer isto. É

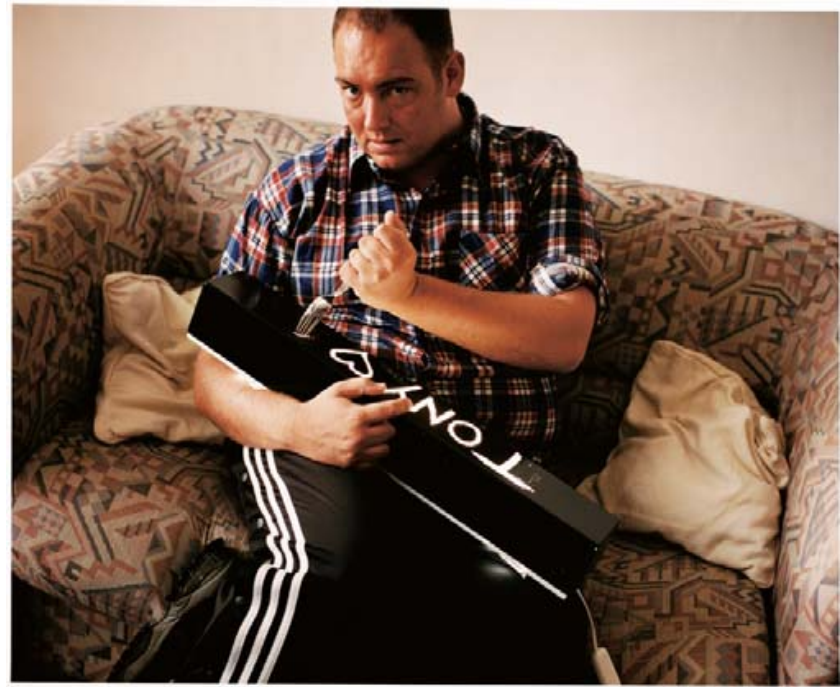
inegável o papel ativo

Fig. 21: Do Scratch Marti Quixé

que tem o indivíduo sobre o resultado formal e simbólico que o objeto assumirá. Entretanto, apesar da ampla liberdade que possui para modificar de diversas maneiras o objeto, a interação do indivíduo sobre o objeto é uma possibilidade criada pelo designer e, ainda assim, insere-se num conjunto maior de relações também ргojetadas pelo mesmo рага ргорiciar a experiência. Nesse caso, o processo de design envolve a produção do objeto concreto e as 
possibilidades de interações especificamente potenciais do indivíduo sobre 0 mesmo. A inteгас̧ão efetiva do indivíduo com o objeto e as relações simbólicas que este adquire constituem os elementos que compõem 0 âmbito da experiência e já não pertencem mais ao processo de design, de onde se conclui que o individuo não participa desse último.

Assim, pode-se dizer que a experiência surge a partir do trabalho do designer de maneira indireta, no momento em que este projeta e cria condições potenciais рага que ela se realize. Como já dito anteriormente, este é o aspecto principal que †огna mais precisa a expressão design рага a experiência ao invés design da experiência. É importante frisar, entretanto, que no momento em que o designer projeta o objeto e outros aspectos ligados à interação, à mediação e ao formato que a informação pode assumir, configurando mensagens, todo seu processo de concepção é norteado a partir da visualização de algumas das experiências possíveis. Partindo desse raciocínio, é possível assim dizer que o designer projeta também diretamente algumas experiências e não apenas as condições рага que esta se realize e que tais componentes que fomentam a experiência, dentre os quais o próprio objeto, podem ser entendidos como subprodutos nesse processo. Entretanto, o conjunto formado tanto pelas experiências previstas quanto pelas não previstas durante o processo de design estão ligadas à figura do designer, visto que esse conjunto surge a partir da combinação de parâmetros criados 
рог ele. Ainda que o designer não tenha domínio de todas as combinações possíveis que podem levar a experiências diversas, ele é o produtor absoluto dos parâmetros combináveis, o que the confere a autonomia do processo de design. Além disso, рог envolver aspectos subjetivos que compõem o próprio sujeito que terá a experiência, esse universo nunca poderá ser dominado com ргеcisão. Depreende-se desta abordagem a absoluta autonomia do designer como único autor no ргоcesso de design рага a experiência, inclusive, como visto, nos casos em que as relações projetadas envolvem a intervenção do indivíduo sobre produtos concretos, alterando suas características físicas de maneira definitiva.

Acerca da questão social envolvida neste processo, Benjamin [1987b], estabelece uma distinção importante entre vivência e experiência7. Enquanto a ргimeira seria uma relação superficial, controlada e rotelrizada por informações definidas que dão forma a uma †агеfa, a segunda compreende uma relação mais densa, composta por mensagens de limites menos rígidos e abertas a interргеtações variadas, construindo a possibilidade de desenrolarem-se nаггativas diversas. A abordagem de Abbagnano [1999] é de grande importância ао ргорог entender a experiência como o produto da relação entre os fluxos da consciência do indivíduo com acontecimentos do mundo externo e ou com os

${ }^{7}$ Esta diferenciação será explicada com maior profundidade no item 2.5.4. do capitulo 2. 
fluxos da consciência de outros indivíduos. Na mesma linha Manzini; Meroni [2005] explicam:

Quando estamos de fronte a uma experiência de fluxo, vivemos sempre uma sensação de ativação e de integração com o mundo externo e com outras pessoas. [MANZINI; MERONI, 2005]

Partindo destas definições, рага a verificação de outros aspectos constitutivos do design рага а experiência talvez consigamos entender o real papel dos objetos neste contexto. É possível assim dizer que, dentro deste sistema que leva à experiência, tais objetos surgem como eventos e dinamizam e movimentam o mundo com o qual o indivíduo realiza suas trocas, de forma que a simples presença do objeto já constitui um desses eventos. É importante salientar ainda, que dominar o caráter mediador e de interação dos objetos não é o único requisito рага se ргоjetar uma experiência. Cabe ao designer recolocar-se frente a sua formação tradicional e tomar também рага si os desafios da Filosofia e da Psicologia na †агеfa de entender a ргópria consciência do homem contemporâneo e do traço pós-moderno que ele carrega.

Assim, tecnociência, consumo personalizado, arte e filosofia em †orno de um homem emergente ou decadente são os campos onde o fantasma pós-moderno pode ser surpreendido. (...) A participação social, assim, se orienta рага pequenos objetivos ргagmáticos e /ou personalizados, embutidos na micrologia (nos pequenos espaços) do cotidiano: Um sujeito pós-moderno pode ser ao mesmo 
tempo programador, andrógino, zen-budista, vegetariano, integracionista, antinuclearista. [SANTOS, 2006, p. 13]

Certeau [1996] oferece uma possibilidade de leitura do design para a experiência que permite verificar um potencial transformador embutido nas práticas cotidianas de relação com o objeto, ainda que mantidas as relações tradicionais do design com o consumo e o mercado. Nessa linha, abre-se um espaço рага enхегgar, nas diversas possibilidades de аргоргіação e reаргоргіação dos produtos massivos, o afloramento de outros sentidos, extrapolando o recorte simbólico imprimido na produção.

Sob essa perspectiva, o sujeito colocado na posição de consumidor continua inscrito numa relação hierárquica imposto pela produção em massa na qual se fundamenta o design industrial, mas não é um ator passivo. Também instaura uma outra produção, fabrica relações com os elementos que o designer the coloca a disposição. Essa leitura é possível por entender que esta fabricação não se faz notar na instância dos próprios objetos, mas na forma de manuseá-los, na sua аргоргiação de forma a abrir espaço para que a cultura popular passe a formular-se e expressar-se em artes de fazer.

As práticas tem uma lógica, colocam em jogo uma ratio popular, uma maneira de pensar investida numa maneira de agir, uma arte de combinar indissociável de uma maneira de usar [CERTEAU, 1996, p. 43] 
As práticas dadas pelo designer tem, nessa perspectiva, um caráter mais aberto e menos impositivo, na medida em que suas relações de força dependem do contexto, da dinâmica cotidiana e de aspectos subjetivos que compõem 0 próprio indivíduo.

Entender o design рага a experiência à luz fornecida рог [erteau [19996] abre a possibilidade de entender aspectos conflitivos e contraditórios a partir das quais se permite questionar a veracidade do сагáter impositivo que surge quando setores populares se apropriam dos objetos produzidos sob a intenção massiva, na qual se fundamentam quase todos os produtos do design. Verifica-se um papel importante do design para a experiência na articulação desses conflitos, ргopondo práticas em cuja орегас̧ão de аргоргiações e coenvolvimento com tais produtos surge não apenas na forma de reprodução social, mas também com a postura de resgatar o cotidiano como espaço de reflexão.

\subsection{0 uso das mídias digitais no fomento de experiências}

Como espécie do gênero design рага a experiência, há ainda uma linha cujas propostas buscam сгіar interações e fomentar experiências explorando a tecnologia digital. De um modo geral, essa vertente visa repensar aspectos de 
design e comportamento tendo como foco o uso da tecnologia como instrumento de comunicação e ampliação do real, oferecendo ao indivíduo novas possibilidades de manipulação e exploração do cotidiano que o cerca. Isso se faz a partir da dimensão imersiva dessa ampliação da realidade na medida em que atrai a atenção e os sentidos do observador рага a cena ou evento, conferindo-lhe um maior poder de concentração frente ao mesmo.

[sikszentmihalyi [1991] enumera uma série de condições рага a obtenção de uma experiência otimizada. Dentre elas duas apresentam maior relevância no trabalho de investigar o papel das mídias digitais neste sistema. A ргіmeira aponta como essencial um nível significativo de concentração no evento do qual emergirá a experiência. A segunda impõe um equilíbrio entre o desafio (evento) e a capacidade do indivíduo de absorvê-lo. Partindo destes princípios, pode-se dizer que as mídias digitais além de dinamizadoras nas trocas que o indivíduo realiza com o mundo e com outros indivíduos, gегando acontecimentos no ambiente externo, ргорorcionam também as duas condições tidas рог [sikszentmihalyi [1991] como essenciais para a realização de uma experiência. Num primeiro momento, elas estendem as capacidades de interação e comunicação com instâncias externas ao indivíduo permitindo que o intercâmbio de fluxos com o qual interage sejam absorvidos em um escala maior pelos sentidos individuais. Da mesma maneira, elas também possuem a capacidade de геorientar estes sentidos, possibilitando uma maior concentração frente a uma 
situação, †огnado-a potencialmente mais capaz de ser аргеendida e, dessa forma, ргomover experiências.

As mídias são extensões de nossos sentidos ao domínio público. (...) Cada mídia amplifica a função de um sentido particular - a lente de uma webcam estende o alcance de ação do olho. Ao mesmo tempo, ela atenua ou "amputa" os sentidos restantes, tais como o cheiro e o toque. (...) A razão do som no cinema ser ligado tão alto é porque de outra maneira não ouviríamos a trilha sonora de tão concentrados que ficamos nas chocantes imagens que nossos olhos têm de processar. As mídias são extensões dos elementos do corpo, dos órgãos dedicados a perceber, monitorar е гegulá-lo. [MULDER, 2004, p. 122]

A ampliação da realidade proporcionada pelas mídias digitais retoma uma discussão antiga sobre o caráter das experiências que acontecem apoiadas em simulações. 0 questionamento acerca da simulação tem suas origens na filosofia clássica. A teoria platônica especulava uma posição baseada no contraponto entre verdadeiro e falso, na qual o simulacro surge como uma imagem enganosa, um artifício disfarçado de natureza. No caminho contrário, a posição de Lucrécio, explicita a potencialização dos efeitos sensoriais propiciado pela simulação, entendendo-a como um espaço fluente das superfícies que propicia o contato entre seres e coisas. Um dos problemas da abordagem de Platão é que ela impõe uma fronteira rígida e estável entre razão e sentidos, o que sempre foi questionado pela Psicologia. 
Accioly [2006] expõe seu entendimento acerca do conceito de simulação, salientando que num mundo em processo de convergência digital a distinção entre original e cópia perde sua validade, o que nos obriga a rever antigos postulados sobre a dualidade verdadeiro/falso que dava suporte ao sentido clássico de simulação como farsa.

A popularização das tecnologias informacionais, desde meados do século 20, introduziu a simulação tecnológica na nossa vida cotidiana, produzindo mudanças no estatuto da experiência e da realidade. [ACCIOLY, 2006]

É importante ressaltar que eventos simulados não estabelecem uma relação de oposição com eventos que compõem o real. Em primeiro lugar porque o conceito de simulação nasce a partir de uma diferenciação que a correlaciona com a idéia de originalidade e não de realidade. Em segundo lugar, porque essa relação entre original e simulado não se constrói por oposição, mas por complementaridade. Assim, a simulação surge a partir de um evento tido como original e com o qual estabelece uma relação de similaridade. Dessa forma, tanto eventos simulados quanto eventos entendidos como originais circunscrevem-se dentro de um conjunto que compõem instâncias da realidade.

De modo semelhante, a posição de Bergson [1999] ao conceber o раг conceitual matéria/memória рага геfletir sobre a natureza da регсерса̃o, recoloca sob uma outra perspectiva a dicotomia clássica sujeito/objeto e algumas de suas 
derivações como mente/mundo e natureza/cultura. Dessa forma, abre espaço рага se pensar o conhecimento a partir de hibridações e interferências. Um dos pontos importantes desta abordagem é que ela fornece subsídios рага uma leitura menos conservadora de ргоpostas que visam explorar o design de objetos a partir da combinação original/simulado, analógico/digital e, indo além, até mesmo biológico/eletrônico, como propõe a Bioengenharia.

Nesse contexto, Accioly [2006] coloca ainda que o potencial da simulação tecnológica não se deve exatamente ao avanço das tecnologias digitais, mas sim ao entrelaçamento de digital e analógico, incluindo a capacidade do algoritmo digital de produzir eventos com os quais interagimos de maneira analógica. Assim, o potencial combinatório рог meio de рrogramações aritméticas discretas no qual se fundamenta o código binário e as tecnologias digitais torna possível simular eventos capazes de serem manipuladas analogicamente pelo indivíduo. Dessa forma, quanto mais se sofisticam os modelos algorítmicos, mais perfeitamente analógico é o efeito que eles produzem nos eventos simulados. Essa dinâmica dá à simulação o poder de embaralhar fronteiras que balizam a nossa percepção ordinária do real, instaurando a indecidibilidade entre o original e o simulado.

Assim, num primeiro momento, a tecnologia privilegia o digital, sobretudo no mundo contemporâneo, que realça a dimensão do cálculo, do algoritmo. Entretanto, no momento em que se põe em cena, a simulação dissimula o 
algoritmo е аргеsenta sua face analógica. Рагесе ser uma ргоpriedade singular dessa estratégia cognitiva a contínua reversibilidade entre analógico e digital. Ela se define tanto pelo modelo (ênfase no digital) quanto pela referencia uma entidade original (ênfase no analógico). Este aspecto coloca uma dualidade рага o código e a informação, apontando рага uma іггеdutibilidade do ргоcesso informacional tanto ao modo digital quanto ao analógico. Esta tendência surge na contemporaneidade como um desafio tecnológico e aponta cada vez mais рага uma †ransdisciplinaridade na ciência, aproximando teóricos da informação e da física às ciências da vida. A rigor, entretanto, a expressão retorno ao analógico пão é adequada рага explicar a dinâmica das tecnologias informacionais. Elas não substituem o analógico pelo digital, mas sim os entrelaçam cada vez mais. De um modo geral, ousadias analógicas fertilizam e fazem proliferar as tecnologias digitais e vice-versa [ACCIOLY, 2006].

0 domínio desses conceitos e das possíveis relações entre eles surgem com grande importância no âmbito do design para a experiência apoiado no uso das tecnologias digitais. Partindo de uma analise geral do sistema de relações рrojetado pelo designer рага fomentar a experiência, é possível dizer que esse sistema continua aberto mesmo com o emprego de mídias digitais produzindo simulações, na medida em que esta é apenas um dos parâmetros que dão forma à experiência. É fundamental entender que se a simulação implica numa redução da complexidade de alguns aspectos do evento original ao 
nível do previsível e do ргоgramável, рог outro o гергoduz atribuindo-the possibilidades que não estariam acessíveis na maneira original e, ргoduzindo, assim, uma complementação de instâncias da realidade.

Somente quando uma simulação produz efeito no real, isto é, quando atinge plenamente a sua meta e gега acontecimento, o experimento se reinscreve no tempo e se converte em experiência. Nesse momento, a complexidade e a indeterminação retornam. [ACCIOLY, 2006]

Vale ressaltar que no âmbito do design рага a experiência a simulação é apenas um dos componentes o sistema que leva a experiência. Assim, o recorte da ргоgramação digital atinge apenas a simulação. Dessa forma, embora o protocolo de ргogramação vise o controle, ela não chega a alcançá-lo de forma absoluta рага todo o sistema porque este compõe-se também de instâncias па̃o ргоgramadas, dentre as quais se incluem aspectos subjetivos que compõem o рго́prio indivíduo.

Assim, sob uma perspectiva cibernética, que estuda a circulação de mensagens entre máquinas e pessoas, cabe lembrar que o sistema projetado pelo designer рага ргоmover a experiência engloba, dentre outras coisas, o indivíduo e seu modo digital e analógico de pensar. Compõem também esse sistema outros objetos comuns do cotidiano que constituem-se, antes de tudo, como símbolos analógicos emissores de mensagens que evidenciam aspectos acerca as relações e o contexto que os envolvem. 
Todo processo cognitivo comporta a dualidade analógicodigital. 0 modo analógico refere-se mais diretamente à ação, ao согрo, ao aparelho sensório-motor e às funções de integração. Matizes são percebidos analogicamente. 0 modo digital, por outro lado, é enfatizado na memória, no reconhecimento de padrões, nos automatismos, reações reflexas e funções de fragmentação. Contrastes extremos são percebidos digitalmente. A dúvida é analógica, a certeza é digital. Incessantemente essas funções se entrelaçam e hibridam - a repetição de padrões abrindo caminho рага a variação e a criação, a criação sedimentando-se por sua vez em novos padrões numa sucessão infinita." [ACCIOLY, 2006]

É importante ressaltar um ponto importante já exposto que entende que todos os objetos constituem-se como mídias quando colocam-se numa relação estabelecendo algum tipo de mediação. Entretanto, ao inserir-se a tecnologia digital, tais objetos tornam-se capazes de potencializar ainda mais a comunicação, acelerando o рrocessamento de informação e 0 fluxo de mensagens e criando assim, novas possibilidades de interação e аргоргiação de eventos. Enquanto nos objetos tradicionais as mensagens emanam de sua significação estática dentro de um contexto variável que os fazem emergir como гергеsentação, em objetos acrescidos de tecnologia digital, as mensagens emanam do funcionamento desse contexto variável a partir do qual o objeto expõe um funcionamento.

Um outro aspecto importante a ser considerado revela ainda que, ао ргоjetar um conjunto de parâmetros e objetos potencialmente suscetíveis de fomentar 
experiências, tais entidades podem envolver inclusive, além da mídia digital e da interação desta com o indivíduo, a interação com outros objetos comuns ligados ao contexto real que compõe o cotidiano. Nesse sentido, as mídias digitais surgem em algumas propostas, рог exemplo, ргоmovendo um re-olhar рага 0 mundo e рага os objetos comuns que, рог se constituírem como símbolos analógicos, †ambém emitem mensagens e são partes constituintes desse cotidiano. Uma mídia digital, ao геcolocar um olhar sobre outros elementos que componham um contexto sob o qual se deseje ргоmover uma experiência como, рог exemplo, uma maçã, uma luminária ou uma conta de água, pode induzir uma reflexão sobre o ato de comer, de acender e apagar luz, ou sobre o consumo de água. Esta reflexão só é possível porque tanto a maçã, quanto a luminária ou a conta são, ao mesmo tempo, objetos e símbolos concretos que podem transmitir mensagens por analogia com o contexto que ocupam, englobando-se neste último, inclusive as relações projetadas pelo designer.

Assim, o uso das tecnologias digitais pelo design рага a experiência insere-se na cultura contemporânea propondo pensar os objetos sob uma nova perspectiva ética e estética, sem recair em binômios anacrônicos como o verdadeiro/falso e forma/função. Surge como ressalva, entretanto, entender que tal proposta não visa aderir a uma cômoda indiferença frente a algumas questões que permeiam o âmbito destas questões, o que acabaria por levar a 
uma despotencialização do objeto como fеггamenta cognitiva potencializadora dentro desse sistema que leva à experiência.

Dessa forma, as mídias digitais participam da experiência projetada pelo designer, potencializando um conjunto de relações envolvendo instâncias do realidade, tanto originais e concretas, quanto simuladas e virtuais, рropondo uma complementaridade a cегсa das mesmas e, dessa maneira, promovendo uma valorização dos aspectos que dão forma à vida social e ao mundo em que vivemos.

A utilização de mídias digitais surge como um instrumento importante no resgate de aspectos do âmbito social por meio do fomento de experiências. Autun [1993], expondo o pensamento do filósofo Gilbert Simondon, resume com extrema precisão as competências do designer contemporâneo e aponta a importância de objetos construtores de mediações no cotidiano de forma a revalorizá-lo.

O designer é um produtor de sensibilidades, de modos de existência social, de práticas de expressão coletiva. 0 produto não é objeto, łampouco coisa. Ele é um germe em †огno do qual um mundo começa a existir. [AUTUN, 1993, p. 03] 


\subsection{Notas para a leitura dos produtos do design para a experiência.}

0 caráter recente dessa nova forma de pensar o design somado a existência de modelos que parecem tão enraizadas no dia-a-dia das pessoas ainda funciona como um entrave рага algumas propostas e para o estudo mais ргеciso das bases e dos fundamentos teóricos do design рага а еxрегiência, sobretudo quando se insere a questão das tecnologias de informação e comunicação. Como resultado dessa dificuldade, o que tem se percebido a partir de uma leitura panorâmica dos exemplos coletados é que grande parte das ргopostas tomam como ponto de partida рага sua análise questões práticas e técnicas de exploração das tecnologias de informação e comunicação nos objetos, deixando em segundo plano aspectos importantes referentes aos atributos conceituais dos objetos. Esse fato dificulta os trabalhos de pesquisa que se proponham, a partir de uma análise de um conjunto coletado, produzir uma análise qualitativa de produtos de design, como propõe este trabalho.

Entretanto, ao longo do processo de desenvolvimento dos conceitos aqui аргеsentados e a partir do entrelaçamento com outras pesquisa do Nomads.usp que se propunham não apenas em desenvolver quadros teóricos que permitissem lег com maior ргеcisão os objetos, mas também concebe-los a partir de formulações ргáticas, foram elencados alguns conceitos entendidos como de suma importância a serem considerados na análise conceitual dos 
objetos. Estes conceitos estão apresentados a seguir, bem como o quadro teórico que se desenvolveu em torno de cada um deles.

\subsubsection{Comunicação, mensagem e informação}

De um modo geral, a comunicação pode ser analisada sob vários aspectos subdividindo-a em espécies distintas de acordo com os critérios adotados. Uma destas espécies é chamada interpessoal e, рага геalizar-se, utiliza apenas os atributos físicos próprios do corpo humano dos interlocutores, como a fala, a audição, a visão, o movimento, o pensamento, entre outros. Contrapondo-se a esta ргіmeira espécie, surge a comunicação mediada que envolve a utilização de dispositivos técnicos, nos quais as mensagens são codificadas na fonte e decodificadas no destino com o uso de sistemas convencionados de signos ou símbolos diversos, como os sonoros, os escritos, os iconográficos, e os gestuais. Este segundo caso pode englobar tanto os sistemas ${ }^{8}$ de comunicação indivíduo-máquina9 como sistemas indivíduo-máquina-indivíduo, sendo que, neste último, o objeto apresenta-se como uma forma de mediação entre os

\footnotetext{
${ }^{8}$ Littlejohn [1992] define sistema como um conjunto de objetos ou entidades que se inter-relacionam entre si formando um todo.

9 Termo proposto por Wienner [1968] ao formular sua teoria cibernética que descrevia a relação de comunicação entre um ser humano e um objeto dotado de certa capacidade de comunicativa a partir da utilização de tecnologias de informação e comunicação (TIC). A palavra máquina deve ser entendida, no contexto atual, no sentido de qualquer objeto ou dispositivo que tenha como inerente algum tipo de TIC que the permita comunicar ou mediar comunicação.
} 
interlocutores do sistema. Рага essa distinção entre comunicação interpessoal e mediada surge, portanto, como critério de segregação a presença ou não de dispositivos técnicos envolvidos no processo de comunicação. Entretanto sob uma outra perspectiva que toma como critério as características dos interlocutores envolvidos, a comunicação interpessoal surge quando осогге a troca de mensagens entre indivíduos - seja diretamente рог meio apenas de seus atributos físicos, seja também рог meio de dispositivos tecnológicos enquanto a comunicação mediada refere-se especificamente à troca de mensagens apenas entre indivíduos e máquinas.

Mitchell [2000] ргорõe outras distinções interessantes a serem consideradas no âmbito da comunicação e ressalta algumas das características principais de cada uma das espécies que resultam desta classificação. A primeira distinção ргoposta pelo autor considera aspectos temporais envolvendo o recebimento e envio de mensagens originando as espécies síncrona e assíncrona. A segunda, considera aspectos espaciais envolvidos na troca de mensagens e dá origem às espécies local e remota.

Uma outra ponderação importante acerca desse contexto atenta para o fato de que em algumas abordagens científicas os conceitos de comunicação e interação são tratados de maneira bastante correlata. A explicação рага isto se deve, sobretudo, ao fato de que em ambas está presente a troca de mensagens. Sobre esse aspecto, entretanto, uma distinção apresenta-se 
também como fundamental рага a análise aqui ргоposta: enquanto a interação геfere-se mais diretamente às formas que as ações podem assumir num sistema em que há troca de mensagens, a comunicação encontra-se mais ligada ao conteúdo dessas mensagens e à narrativa comum que envolve os interlocutores.

Em uma dessas abordagens, Watzlawick [1993] entende que comunicação realiza-se рог meio da interação entre diversos elementos simbólicos. 0 processo comunicativo é visto como uma relação bem mais ampla do que a simples troca de mensagens faladas. Dentro dessa linha de pensamento, toda e qualquer forma de comportamento culminaria em algum tipo de comunicação.

(...) uma vez aceito todo o comportamento como comunicação, não estaremos lidando com uma unidade de mensagem monofônica mas com um complexo fluido e multifacetado de numerosos modos de comportamento - verbais, tonais, posturais, contextuais, etc. - que, em seu conjunto, condicionam o significado de todos os outros. Os vários elementos desse complexo (considerado como um todo) são capazes de permutas muito variadas e de grande complexidade, que vão desde o congruente ao incongruente e paradoxal" [WATZLAWICK, 1993, p.18]

Paralelamente a essas idéias, Rabaça; Barbosa [2001], também entendem a comunicação interpessoal como uma relação muito mais ampla do que a troca de mensagens verbais. Acrescentam ainda que para caracterizar uma relação comunicativa é essencial a existência de algum tipo de resposta discriminativa 
do indivíduo à mensagem que the foi enviada. Sob esta ótica, a mensagem à qual não é dada uma resposta não produz comunicação. Esse pensamento estabelece uma relação de causa e efeito entre as mensagens trocadas entre os interlocutores e, de certo modo, gera também uma аргоximação entre os conceitos de interação e comunicação.

\begin{abstract}
Comunicação não se refere somente à transmissão verbal, explícita e intencional de mensagens. (...) 0 conceito de comunicação inclui todos esses processos por meio dos quais as pessoas influenciam outras pessoas. (...) Esta definição se baseia na рremissa de que todas as ações ou eventos têm aspectos comunicativos, assim que são percebidos por um ser humano; implica, além disso, que tal percepção modifica a informação que 0 indivíduo possui e, por conseguinte, influencia esse indivíduo. [RABAÇA; BARBOSA, 2001, p.08]
\end{abstract}

Essa idéia de comunicação, рага a qual toda a mensagem deve haver necessariamente uma resposta, apóia toda a relação comunicativa no binômio ação-reação e coloca em segundo plano os outros elementos que a compõem. Рага Berlo [1991], tal simplificação do sistema comunicativo nega o ponto fundamental no estudo da comunicação que é entendê-la, acima de tudo, como ргосеsso.

Os termos ação e reação rejeitam o conceito de processo. Implicam que há um começo na comunicação (o ato), um segundo acontecimento (reação), acontecimentos subseqüentes, etc, e um fim. Implicam a interdependência dos 
acontecimentos dentro da seqüência, mas não implicam o tipo de interdependência dinâmica que se compreende no processo da comunicação" [BERLO, 1991, p. 43]

Fisher [1987] ргорõe uma definição que constrói relações ainda mais estreitas entre os conceitos de comunicação e interação. Рага o autor, a comunicação interpessoal é entendida como a паггativa que envolve e conecta diversos elementos dentre os quais os próprios interlocutores. Essa паггativa seria construída pela interação entre comportamentos, interргеtações, interlocutores e até o contexto espaço-temporal e social no qual ela se realiza. Sob essa ótica, o indivíduo não figuraria como pólo produtor da comunicação, mas como um dos elementos que uma narrativa comum, resultante do processo comunicativo, envolveria como um todo. Num contexto mais amplo, essa †еoria se opõe de maneira direta ao modelo transmissionista formulado na década de 50 pela teoria da comunicação, sobretudo, рог гоmper com a idéia de hierarquia entre emissor е гесерtor de mensagens.

A teoria da comunicação formulada na década de 1950 foi uma conseqüência direta do boom ocorrido na indústria de telecomunicações no período pósgueггa, e tomou corpo com o trabalho de Shannon; Weaver [1987]. A formulação matemática ргоposta рог eles рага essa †еогia visava o estudo quantitativo da informação em mensagens e também do fluxo de informação entre emissores e гесерtores. Tal †еогia tinha aplicação voltada рага as práticas das ciências eletrônicas, mas passou, com o tempo, a ser utilizada 
também рага explicar a comunicação social e interpessoal. Discutindo o trabalho de Shannon e Weaver, Littlejonh [1982] salienta que a idéia básica do pensamento desses dois teóricos gira em †огno do entendimento de que as mensagens fornecem informações. Aponta como importante salientar ainda que esses dois conceitos estão ligados a aspectos matemáticos e quantificantes e, рог isso, são entendidos рог essa tеогіa de forma bastante diferente da adotada pelo senso comum.

A informação é uma medida de incerteza ou entropia numa situação. Quanto maior for a incerteza, maior será a informação. Quando uma situação é completamente previsível, nenhuma informação está presente. A maioria das pessoas associa informação à certeza ou conhecimento e, рог conseqüência, essa definição da teoria da informação é muito confusa. Tal como é usado pelo teórico da informação, o conceito não se геfere a uma mensagem, a fatos ou a um significado. É um conceito vinculado somente à quantificação de estímulos ou sinais numa situação. [LITTLEJONH, 1982, p. 22]

Essa definição de informação valoriza a quantificação do número de possibilidades de escolha entre alternativas disponíveis e remonta ao conceito de entropia. A entropia pode ser entendida como a medida da desordem ou da imprevisibilidade da informação. Conforme definem Shannon; Weaver [1977]:

\footnotetext{
${ }^{10}$ Littlejohn (1992) define entropia como sendo o grau de randomicidade ou falta de previsibilidade numa situação, resultando em incerteza. A informação é tida como uma medida de incerteza. Quanto maior a incerteza, maior a informação inerente à situação.
} 
a palavra informação não se refere tanto ao que você efetivamente diz, mas ao que poderia dizer. Isto é: informação é uma medida de sua liberdade de escolha quando seleciona uma mensagem. [SHANNON; WEAVER, 1977, p. 34]

Wiener [1968] ргорõe uma definição menos matemática рага o †егmo estabelecendo relações mais amplas e interativas entre individuo e mundo exterior. Entende as mensagens como a forma de organização e configuração da informação. 0 autor propõe uma definição que busca juntar aspectos técnicos desse processo com um componente humanístico que visa discutir o modo como o indivíduo reage frente a seu mundo habitável.

Informação é o termo que designa o conteúdo daquilo que рermutamos com o mundo exterior ao nos ajustarmos a ele, e que faz com que nosso ajustamento seja nele percebido. 0 ргоcesso de гесеber e utilizar informação é o processo de nosso ajuste às contingências do meio ambiente em geral. [WIENER, 1968, p. 77]

0 paradigma do processo da comunicação proposto em 1949 por Shannon e Weaver [1987] é conhecido como †ransmissionista рог compreender um fluxo linear de mão única construído a partir da cadeia fonte-transmissor-canalгеceptor-destino. Рага os autores, a mensagem é vista como uma seqüência de símbolos ou signos organizados de acordo com regras e com certo grau de incerteza ou entropia, que, рог meio de estímulos, atingem o receptor serialmente. Nesse modelo, o emissor figura no pólo criativo que molda a 
mensagem que, рог meio de um canal, chegará até um pólo de posição hierarquicamente inferior ocupado pelo receptor.

Como crítica ao modelo transmissionista Reddy [1979] propôs uma relação que - assemelha ao que ela chamou de metáfora do tubo (conduit metaphor). Nesta metáfora, as pessoas, escrevendo ou falando, inserem seus pensamentos ou sentimentos (significados) em palavras. Essas palavras empacotam esses significados e são conduzidas através de um tubo la linguagem) de uma pessoa рага outra. As pessoas, ouvindo ou lendo, retiram os pensamentos e sentimentos de seu interior. Essa metáfora ainda embasa grande parte do entendimento acerca da comunicação de forma que todo o ргocesso é estruturado рага que o emissor envie suas informações através desse tubo рага o seu гесерtor.

Contrapondo-se à metáfora do tubo, Reddy [1979] propõe um caminho alternativo рага conceber a comunicação humana. Assim, o autor sugere que consideremos o fato de que, ao falar um com o outro, somos como pessoas isoladas em ambientes levemente diferentes e аргеsenta uma outra metáfora рага o modelo comunicacional que ele denomina de metáfora dos fabricantes de utensílios. Nessa metáfora, ele busca destacar como a comunicação só se estabelece quando os envolvidos realizam esforços рага que um novo domínio de interações sejam construídas. Evidencia, assim, que o ato comunicativo e o 
processo de comunicação são resultantes de um grande e continuado processo interativo.

Percebe-se assim, que com o desenvolvimento da teoria da comunicação nas décadas de 1960 e 1970, o modelo transmissionista aponta рага um entendimento cuja ênfase reside na interação e não mais na transmissão e quantificação da informação, além de considerar também com maior relevância aspectos relativos ao contexto.

Littlejohn (1982) salienta que a partir do modelo de Shannon; Weaver [1987] surgiram †гês áreas ou níveis de interesse que davam enfoques diferentes aos conceitos formulados pelo modelo transmissionista: o nível técnico, o nível semântico e o nível de eficiência.

A teoria técnica da comunicação tem como objeto de estudo a transmissão e геcepção das mensagens. Descarta totalmente o significado da informação e ргеocupa-se mais com a exatidão de sua †ransmissão, sendo, рог esse motivo, mais aplicada em sistemas comunicativos mediados рог dispositivos tecnológicos, como computadores e redes. Segundo essa †еoria, as mensagens são vistas apenas como sinais a serem transmitidos, †огnando-se іггеlevantes nesse processo o seu significado. Nesse modelo, a comunicação tem início na fonte e estão presentes basicamente 5 etapas: 
[1] formulação ou seleção da mensagem feita pela fonte,

[2] conversão da mensagem em sinais reconhecíveis pelo canal

[3] transmissão dos sinais pelo canal até o receptor

[4] conversão dos sinais pelo гесерtor num formato reconhecível pelo destinatário

Apesar do surgimento de outras ramificações que permitiram entender a †еoria da informação de outras maneiras, a questão técnico-†ransmissionista ainda hoje se encontra bastante enraizada em pesquisas e proposições que se utilizam das novas tecnologias de informação. Traçando um paralelo com os meios de comunicação contemporâneos, Primo [2005] entende que o modelo webdesigner-site-Internet-usuário ainda reflete o modelo da †еoria da informação (emissor-mensagem-canal-гесерtor), de forma que enquanto no modelo informacional o emissor transmite, no novo modelo diz-se que o webdesigner disponibiliza.

Nesse contexto, o segundo nível que se ramificou da teoria de Shannon; Weaver [1987], conhecida como Teoria Semântica da Informação, dá um passo além e cuida do significado da mensagem рага a fonte e o receptor, inserindo a interргеtação realizada pelos seus interlocutores como um ponto chave рага o seu entendimento. 
(...) Em nível semântico, concentramo-nos na comunicação da informação, a qual reduz a incerteza numa situação. ’̀ informação transmitida por uma mensagem que reduz a incerteza numa situação dá se o nome de informação semântica. 0 que se acrescenta aqui à teoria é o elemento humano de interргеłação e compreensão. [LITTLEJOHN, 1982, p. 67]

0 †егсеіго nível derivado da †еогia da Informação tem ênfase na eficiência e trata do impacto ou efeito da informação sobre o sistema. Em termos mais específicos, pode-se dizer que ela cuida do nível de influência da informação sobre о гесерtor.

A teoria cibernética do matemático Norbert Wiener, contemporânea da Teoria da Comunicação, também tratava da questão da comunicação apoiando-se em postulados científico-matemáticos como Shannon; Weaver [1987]. No entanto, o trabalho de Wiener [1968] inova no sentido de vislumbrar de antemão o impacto que o desenvolvimento das tecnologias de comunicação teriam sobre a sociedade. Em sua obra intitulada "Cibernética e Sociedade: 0 uso Humano dos seres humanos", o autor deixa clara a ênfase social e humanística dada ao seu trabalho. Suas teorias encontram na atualidade ressonância bastante significativa.

A tese deste livro é a de que a sociedade só pode ser compreendida através de um estudo das mensagens e das facilidades de que disponha; e de que, no futuro desenvolvimento dessas mensagens e facilidades de 
comunicação, as mensagens entre homens e máquinas, entre as máquinas e o homem, e entre a máquina e a máquina, estão destinadas a desempenhar papel cada vez mais importante. [WIENER, 1968, p. 11]

Wiener propunha também uma aproximação por meio da comunicação entre seres humanos e máquinas. É característico em seu †гаbalho entender as relações que se estabelecem na comunicação entre homens e máquinas de maneira muito semelhante às que осоггеm no âmbito interpessoal.

Quando dou uma ordem a uma máquina, a situação não difere essencialmente da que surge quando dou uma ordem a uma pessoa. Por outras palavras, tanto quanto alcança minha consciência, estou ciente da ordem emitida e do sinal de aquiescência recebido de volta. Рага mim, pessoalmente, - fato de o sinal, em seus estágios intermediários †ег passado рог uma máquina em vez de рог uma pessoa é iгrelevante, e em nenhum caso altera significativamente minha relação com o sinal." [WIENER, 1968, p. 21]

Tanto a teoria da comunicação quanto a formulada рог Wiener [1968] são, ao mesmo tempo, resultantes e realimentadoras do desenvolvimento da indústria de telecomunicações. Com o desenvolvimento de novas tecnologias de comunicação de processamento mais veloz e apoiadas em redes e sistemas computacionais, novos caminhos de discussão foram trilhados e novas lacunas emergiram. Frente à rapidez de processamento e ao bombardeamento constante de informação realizado pelos meios de comunicação atuais, levantaram-se questões sobre as perdas trazidas рага o ргоcesso 
comunicativo. Muito antes, Benjamin [1987a] já discutia essa tendência, identificando no próprio comportamento interpessoal e geracional um certo empobrecimento da comunicação. 0 que tem se percebido sobre isso é que, como resultado desse descompasso entre os ritmos do homem e os da tecnologia, tem emergido uma comunicação, em muitos casos, descontextualizada e empobrecida, desprovida das паггаtivas que compõem a riqueza do cotidiano das pessoas.

É nesse contexto que o design рага a experiência tem buscado também explorar essa lacuna fazendo proposições a cerca do tema comunicação. Dessa forma, muitas ргоpostas formuladas pelo design рага а experiência envolvendo tecnologia de informação e comunicação têm se focado não no aumento de sua eficiência, mas sim nas possibilidades de sua realização como experiência.

\subsubsection{Interação}

A partir da acepção morfológica da ргópria palavra, a interação pode ser entendida como a relação resultante da existência de um canal comum que permite a atuação de um interagente sobre o outro e vice-versa. 0 prefixo latino inter- ${ }^{11}$ salienta que o

\footnotetext{
${ }^{11}$ pref (lat inter) Significa entre, dentro de, no meio de.
} 
ргоргiamente às ações que compõem um sistema, mas sim à ligação que as envolve рог meio de um canal comum. Dessa forma, a interação resulta de uma relação de liberdade mútua рага agir existente entre os interagentes que compõem um sistema interativo, ainda que as ações de cada interagente utilizadas рага atuar um sobre o outro possam assumir formatos diferentes. Primo [1997], геforça essa idéia e afirma que a "interação" deve ser entendida como uma "ação entre" os participantes de um encontro.

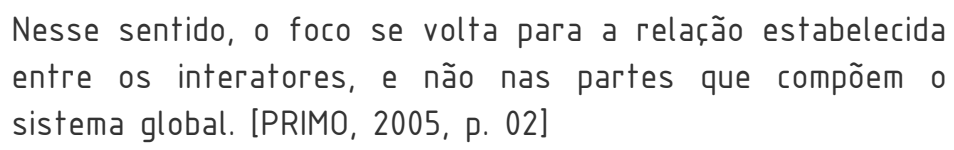

No âmbito interpessoal, Watzlawick [1993] enхегga a interação como uma relação de interdependência entre indivíduos рага com seu meio e seus рагеs, de forma que cada comportamento individual afeta e é afetado pelo comportamento dos outros. Рага Вordenave [2004], a existência do indivíduo já ргеssupõe o surgimento de formas de interação na medida em que este se encontra em constante adaptação ao meio físico que ocupa e com os elementos que o constituem. Essa adaptação constante com o meio e com seus pares resulta em uma interação que objetiva o equilíbrio entre o indivíduo e ambiente, e se realiza рог meio da transformação de ambos ou com a acomodação de um sobre o outro:

Dicionário Houaiss da Língua Portuguesa. Objetiva: São Paulo, 2001 
A pulsação vital permanente no interior da pessoa consiste num ргесário equilíbrio dinâmico que, рага ser mantido, tem obrigatoriamente de se adaptar ao meio ambiente físico e social que rodeia o organismo, quer se acomodando a ele, quer tentando transformá-lo". [BORDENAVE, 2004, p. 12]

Outras áreas do conhecimento podem estabelecer análises mais ргofundas de um sistema interativo e identificar de maneira mais precisa a materialidade e outros atributos dos pólos interagentes.

Em física quântica, a interação é entendida como a ação de um objeto físico sobre outro, de forma que, esses objetos físicos podem ser considerados desde partículas pontuais até campos quânticos." [GILMORE, 1998, p. 56]

Como visto, o modelo inicial ргоposto, рог Shannon; Weaver [1987] рага †еогizar a comunicação se baseava em um fluxo linear de mão única e hierarquizado na figura do emissor. Рог ароіаг-se em postulados matemáticos este modelo аргesentava aplicação bastante restrita e focada na quantificação da informação, descartando os aspectos interativos do ргоcesso comunicativo. Com o tempo, o desenvolvimento da teoria da comunicação e sua apropriação рог outras áreas do conhecimento ampliou sua abrangência e †ornou-a menos rígida e hiегагquizada. Contemporaneamente ela é um modelo aplicado também рага †еогіzar a interação, estabelecendo denominadores comuns entre diferentes áreas do conhecimento. Dessa forma, é possível discutir a interação à luz da teoria da Comunicação sem negar a existência de um canal de mão 
dupla capaz de permitir a interferência de um interagente sobre o outro de maneira гесі́pгoca e пão hierarquizada, ao contrário do que propunha o modelo †ransmissionista inicial.

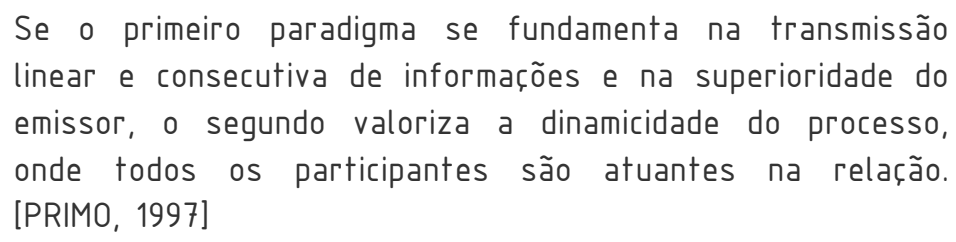

Essa aproximação entre comunicação e interação a partir da teoria de Shannon e Weaver surge pelo fato de que em ambas está presente a troca de informação рог meio de mensagens. Entretanto, enquanto a "interação" tem como foco principal a relação existente entre as ações que levam a essa transmissão de mensagens, explicitando o grau de vínculo entre elas, a comunicação геfere-se de modo mais direto ao conteúdo das mensagens e às maneiras como esse conteúdo envolve os participantes na construção de uma паггаtiva comum.

A relação de vínculo existente entre as ações por meio das quais um interagente agirá sobre o outro pode construir-se de maneiras diversas. A maioria dos autores que buscam discutir os aspectos de tais vínculos caminham no sentido de estabelecer níveis de interação e conseqüentemente mapear sistemas em que a interação осогга em graus mais ou menos interativos. 
Em termos simples, осогге interação quando a ação de um interator desencadeia uma reação em outro. Esta interação pode tег diversos níveis, desde a simples bidirecionalidade até a interatividade. [GILMORE, 1998, p. 39]

A bidirecionalidade está presente principalmente em sistemas que se utilizam de tecnologias computacionais e осогге quando as ações se realizam por meio de um canal comum com fluxo em dupla direção. Um sistema bidirecional caracteriza-se рог um fluxo de mensagens com vínculos mais sutís, mas dotado de rapidez de resposta e de um vasto número de combinações possíveis disponíveis ao usuário. De modo análogo, a interatividade surge em sistemas cujas ações de um dos pólos interagentes арагеcem como respostas a ações advindas de um outro pólo interagente que compõe esse mesmo sistema e vice-e-versa. Constitui-se assim de um vínculo mais forte do que осогге no sistema bidirecional, resultando em uma †гоca de mensagens estruturadas a partir do binômio ação-reação ou causa-conseqüência. Consoante com essa classificação, Ргimo [1997] sugere ainda a existência de uma outra divisão que ргорõe dois tipos de interação: a mútua e a reativa, de forma que, a partir de parâmetros ${ }^{12}$ estabelecidos pelo próprio autor, este define a ргіmeira como sendo plena e a segunda como fraca e limitada.

\footnotetext{
120 autor ргорõe os seguintes parâmetros рага estabelecer níveis de interatividade: sistema: definido рог Littlejohn [1992], como "um conjunto de objetos ou entidades que se interrelacionam entre si formando um todo"; ргocesso: acontecimentos que apresentam mudanças no tempo; орегас̧ão: a produção de um trabalho ou a relação entre a ação e a †ransformação;
} 
A análise dos níveis possíveis de interação de um sistema está diretamente ligada às potencialidades de ação de cada pólo interagente. De um modo geral, assim como na †еогіa cibernética ргоposta рог Norbert Wiener aplicada à comunicação, seria correto dizer que os pólos interagentes de um sistema podem constituir-se рог uma conexão homem-homem, configurando uma interação interpessoal, ou utilizar dispositivos técnicos como осогге nos sistemas homem-máquina e máquina-máquina. No tocante a essa divisão, Berlo [1991] identifica, na interação interpessoal, uma relação de interdependência que se аргеsenta como seu atributo principal. Essa interdependência pode variar em grau, em qualidade e de contexto рага contexto. 0 autor aponta, ainda, a limitação existente quando a interação interpessoal é entendida apenas como ação e геação, a exemplo do que осогге em alguns sistemas que envolvem apenas dispositivos mecânicos ou computacionais (sistemas máquinamáquina). Ao contrário do que ргорõe Wiener [1968], esse pensamento analisa de forma mais profunda as diferenciações entre interagentes humanos e mecânico-computacionais e aponta problemas quando são †razidos, рага o âmbito interрessoal, modelos de interação baseados em ргеssupostos tecnicistas como este. Dessa forma, o modelo apoiado no binômio ação-reação é visto como simplificador do fenômeno interativo рог entendê-lo como um

fluxo: curso ou sequiência da relação;

throughput: os que se passa entre a decodificação e a codificação, inputs e outputs

relação: o encontro, a conexão, as trocas entre elementos ou sub-sistemas;

interface: superfície de contato, agenciamentos de articulação, interpretação e tradução. 
ргоcesso linear e que sempre toma como ponto de partida uma fonte de onde surge apenas a emissão. Berlo (1991), salienta ainda que o feedback ${ }^{13}$ que surge nesse modelo apenas com a função de comprovar a eficácia da mensagem, quando †ransposto de forma absoluta рага o âmbito de sistemas envolvendo seres humanos resulta em uma relação que empobrece outras possibilidades de interação mais profundas, que podem осоггег еntre os indivíduos.

A posição adotada рог Berlo (1991) aproxima-se do interacionismo simbólico, uma das principais escolas de pensamento da sociologia que tem como característica incorрогаг a reflexividade na análise da ação. A base dessa escola foi assimilada pelo pensamento sociológico como parte da psicologia social e é largamente representado em estudos sobre o cotidiano e da interação face-à-face.

O estudo reflexivo e teórico, аргеsenta os pressupostos básicos do Interacionismo Simbólico e trata o significado como conceito central da teoria, de forma que as ações são construídas a partir da interação entre as pessoas. [GIDDENS, 1997, p. 44]

\footnotetext{
${ }^{13}$ Retorno dado pelo receptor ao emissor como resposta a uma mensagem enviada. Este retorno permite ao emissor entender que a mensagem que enviou foi recebida e que a ordem que ela continha (informação) foi entendida e cumprida pelo receptor exatamente conforme exigia a mensagem.
} 
Рага Blumer [1969] são três as premissas básicas рага o Interacionismo Simbólico:

[1] os indivíduos agem em relação às coisas tomando como referência o significado que essas coisas tem рага eles;

[2] algumas vezes, o significado de tais coisas surge de uma interação social que a pessoa tem com seus semelhantes;

[3] esses significados são manipulados e modificados рог meio de um рrocesso interргеtativo, usado pelo indivíduo para lidar com as coisas que ele encontra.

De um modo geral, a teoria interacionista busca resgatar aspectos da interação interpessoal que quase sempre são deixados de lado рог definições que tratam da questão da interação de modo mais geral. As premissas apontadas рог Вlumer [1969] reforçam a importância de entender que um sistema interativo não é constituído apenas рог um conjunto de interagentes, mas também рог outros elementos como as atividades interpretativas, os grupos humanos ou sociedades, a mente, os objetos, os símbolos, os significados, a linguagem, as interconexões das linhas de ação, entre outros.

As interações interpessoais que envolvem algum tipo de dispositivo mecânico ou computacional são chamadas, рог Ргimo (1998), interações interpessoais mediadas. No contexto digital, as interações mediadas podem dar-se 
diretamente com objetos apoiados em tecnologias de informação e comunicação e ou рог meio destes e suas redes. Esse tipo de interação tem sido bastante explorado no desenvolvimento de objetos e interfaces computacionais. Silva (2000) aponta o binômio permutabilidade-potencialidade como um dos pilares da interatividade dentro do contexto computacional:

A liberdade de navegação aleatória é garantida por uma disposição tecnológica que faz do computador um sistema interativo. Esta disposição tecnológica permite ao usuário atitudes permutatórias e potenciais. Ou seja: o sistema permite não só o armazenamento de grande quantidade de informações, mas também ampla liberdade para combiná-las (permutabilidade) e ргoduzir паггаtivas possíveis (potencialidade)." [SILVA, 2000, p. 22]

A interação mediada por objetos que se apóiam nas chamadas tecnologias de informação e comunicação tem sido bastante explorada рог designers que buscam utilizá-las рага fomentar experiências nos indivíduos, enquadrando-se dentro do que propõe o Design рага a Experiência. Numa significação mais ргóxima à †гаbalhada рог alguns designers dessa nova sub-área, Shedroff [2005], autor de vários livros sobre o assunto e pesquisador convidado do Ivrea Interactive Institute ${ }^{14}$, aponta uma definição рага interação dentro do contexto computacional que trabalha com a questão da experiência:

\footnotetext{
${ }^{14}$ http://www.interaction-ivrea.it/en/index.asp
} 
Interação é uma experiência-resposta na qual tanto ator como reator estão envolvidos em uma experiência mutuamente afetiva. Isso significa que o sistema é composto de dois parceiros interativos. No caso de mídias interativas, um parceiro pode ser apenas levemente interativo (como um computador) e também apenas interativo do ponto de vista da programação. Enquanto a maioria das ações do ator computador são o resultado de programação prévia, se as variações forem suficientemente amplas pode-se dizer que esse ator é interativo (faz dele um interator). Em geral, dois humanos (inerentemente interativos) сгіага̃o um sistema interativo ou experiência simplesmente conversando." [SHEDROFF, 2005]

$\mathrm{Na}$ maioria dos casos, a interação mediada ainda encontra-se muito enraizada no modelo fundamentado na idéia de recepção/feedback. Machado [1993] propõe a partir daí uma diferenciação fundamental entre o que é interativo e o que é геativo. Рага ele, um sistema interativo baseado em tecnologia computacional deveria dar total autonomia ao espectador, enquanto os sistemas reativos trabalhariam com uma gama pré-determinada de escolhas.

Boa parte dos equipamentos hoje experimentados ou já comercializados como interativos são, na verdade, apenas reativos. Os videogames, рог exemplo, solicitam a resposta do jogador/espectador (геsposta inteligente em alguns casos; resposta mecânica na maioria dos outros), mas sempre dentro de parâmetros que são as 'regras do jogo' estabelecidas pelas variáveis do programa. Isso quer dizer que nas tecnologias reativas não há lugar ргоpriamente a respostas no verdadeiro sentido do termo, mas a simples escolhas entre um conjunto de alternativas préestabelecidas" [MACHADO, 1993, p. 33] 
0 autor геforça ainda que, nos sistemas meramente reativos, a interação surge como †гоca simbólica a partir de uma hierarquia pré-definida a partir da qual o pólo emissor se torna hegemônico prejudicando as trocas e a plena capacidade de resposta, que se apresenta limitada a um recorte de possibilidades. Williams (1990) chama de "resposta autônoma e criativa" o atributo da interação mediada capaz de †orná-la também imprevisível рага os interagentes e expectadores, a exemplo do que осогге па interação interpessoal. Esse atributo elimina o isolamento das figuras do pólo emissor e do pólo гесерtor da ação, rompendo com qualquer espécie de hieraгquia entre os pólos, que passam a figurar num mesmo patamar como agentes interagentes isonômicos. A relação reativa seria, assim, aquela que não possuísse tal atributo, аргеsentando-se como uma espécie de simplificação do fenômeno interativo. Sua característica principal seria uma forte parametrização roteirizada e de programação fechada que, além de limitar a gama de регсursos possíveis, faz com que estes tenham desfechos definidos a priori e suscetíveis de idêntica repetição. Dilui-se, assim, a liberdade criativa que, рог mais que possa se аргеsentar bastante dinâmica pela alternância dos parâmetros, sempre terá limites já definidos em um momento anterior à realização efetiva das ações.

Fischer [1987] coloca como sinônimos da interação a геlação e a comunicação. Рага ele, а гelação reativa é vista como uma espécie de interação. Esse tem 
sido na verdade o entendimento de grande parte dos profissionais que trabalham com tecnologias computacionais e que se popularizou como senso comum do público leigo. Dentro do campo disciplinar do design рага a experiência, têm surgido propostas de objetos interativos bastante interessantes que exploram o conceito tanto de relação reativa quanto interativa. 0 que se mostra importante frente a essa questão, conforme coloca Primo [1998], é que o entendimento do conceito de interação não assuma a significação mercadológica que circula рог toda parte nos programas de televisão e rádio, nas campanhas de marketing, nas embalagens de ргоgramas de informática e jogos eletrônicos e até mesmo em trabalhos científicos de comunicação e áreas afins. Na mesma linha, Fisher [1987] complementa:

0 que não se pode admitir é que os sistemas reativos se tornem o exemplo fundamental de interação lcomo vem acontecendo nos slogans da indústria informática). Podemos então аргesentá-los como um tipo fraco de interação, sem jamais esquecer das profundas limitações que impõem à relação. Portanto, entende-se que é ргеciso discutir a fundo a interação mútua e plena, рага que se possa, além de se desenvolver o campo teórico sobre o tema, inspirar sistemas informatizados que permitam uma interação criativa, aberła, de verdadeiras trocas, em que todos os agentes possam experimentar uma evolução de si na relação e da relação ргоpriamente dita. [FISCHER, 1987, p. 55] 
Primo [1998] entende ainda que рага o estudo da relação homem-máquina, da comunicação mediada рог estes dispositivos e do conceito de interatividade deve-se partir de estudos que investiguem a interação no contexto interpessoal. Sendo assim, defende que a relação no contexto computacional, que se pretende plenamente interativa, deve ser trabalhada como uma аргоximação àquela que осогге па esfera interpessoal.

Na verdade, essa colocação aponta рага um problema há muito гесоггеnte no desenvolvimento de tecnologias que se propõem lidar com aspectos comuns do dia-a-dia das pessoas. Inúmeras são as pesquisas sobre produtos e objetos que ргорõem facilitar esse cotidiano рог meio de equipamentos mais rápidos, †ornando as †агеfas realizadas na rotina do ambiente doméstico mais precisas e menos pesarosas, permitindo que o homem aproveite mais seu tempo livre. Entretanto, poucas têm sido as pesquisas que buscam construir uma аргоximação real entre a tecnologia que ambiciona inserir-se no cotidiano das pessoas e os aspectos que compõem esse próprio cotidiano. Рara isso, é necessário, acima de tudo, enxergar que o ponto principal de um design que proponha uma contramão da tendência utilitarista não reside em tentar libertar o indivíduo das atividades cotidianas, mas ргеdispor-se a dinamizá-las. 


\subsubsection{Mediação e mídia}

0 conceito de mediação †ransita рог contextos dos mais diversos. Engloba desde as relações presentes nas mais simples atividades humanas, como 0 pensamento e qualquer forma de comportamento do indivíduo, até as relações que se estabelecem com dispositivos tecnológicos. Abbagnano [1999] ргоро̃e a seguinte definição рага o termo mediação:

Em geral é a função que põe em relação dois extremos ou objetos. [ABBAGNANO, 1999, p 242]

Рага o autor, a mediação surge como resposta a uma condição de distância física ou de significado entre dois elementos concretos ou abstratos que, рага realizar-se, utiliza-se de outros elementos intermediários, capazes de atenuar ou reforçar esse distanciamento. Salienta ainda que a mediação está presente em todo tipo de raciocínio ou argumentação de forma que surge mediação quando, рог exemplo, рага se геlacionar duas idéias geralmente se гесогге а uma tегсеіг que se аргеsenta como рагаmetrizadora рага as duas pгimeiras.

\footnotetext{
Toda a lógica se reduz a uma regra muito simples: рага confrontar dois ou mais objetos mutuamente distantes, se utilizam vários objetos intermediários. 0 mesmo осогге quando se quer confrontar duas ou mais idéias, a arte do raciocínio não é mais do que o desenvolvimento deste principio e das conseqüências que dele resultam." [ABBAGNANO, 1999, p. 242]
} 
Рага Debray [1994], a mediação é uma forma de сuгa рага suplantar uma situação que se encontra ausente рог еstar impedida de realizar-se de forma direta e original. É um fenômeno que surge com a intenção de evocar conexão е ргоximidade, mas que acaba resultando na substituição do real рог uma cópia ou tradução da situação original. 0 autor realça ainda o caráter гергеsentativo e de ambivalência da mediação:

(...) mediação é гергеsentar, †огnar presente o ausente. É dar a ver o que não se vê (...) é tornar próximo o distante. [DEBRAY, 1994, p. 12]

Moller [1996] discutindo sobre o significado filosófico do termo mediação entende que esta tem рог †агеfa buscar a entidade que estabeleça a ponte entre elementos opostos ou distantes, construindo uma referência de equilíbrio comum capaz de relacioná-los.

Mediação significa, em primeiro lugar, reduzir coisas opostas a um ponto central ou a partir deste. (...) achar um ponto de equilíbrio, portanto, uma mediação. [MOLLER, 1996, p. 09]

A mediação é entendida рог alguns como inerente à construção cognitiva simbólica do mundo. É a responsável рог огientar o comportamento do indivíduo e é o meio que leva a atuar tanto sobre a natureza selvagem quanto sobre sistemas sociais organizados рага compor qualquer forma de coletividade. Аргеsenta-se, assim, como atributo fundamental da linguagem que leva os 
indivíduos a viver experiências individuais e a constituírem-se como parte da sociedade.

Os seres humanos agem em relação à realidade com base no significado que the atribuem e esse significado provém em ргіmeira instância dos processos de interação social e de mediação simbólica. Tais processos comportam uma dimensão cognitiva - sustentam as гергеsentações sociais da realidade social e natural - e uma dimensão prescritiva indicam os objetivos e as normas de acordo com as quais os indivíduos e as coletividades devem comportar-se. Este ponto de vista significa a adesão a uma perspectiva que realça o papel da linguagem, a qual deixa de ser considerada como instrumento рага se constituir em elemento estruturante das relações sociais. De acordo com esta visão, de certa forma, a mediação lingüística desempenha um papel fundamental na constituição da experiência que temos do mundo. [CORREIA, 1998, p. 19]

Em consonância com essas idéias, Vygotsky [1984] defende que o simbólico e o signo lingüístico operam como uma mediação no processo pelo qual o sujeito se relaciona com ele próprio e com outros indivíduos. Identifica o papel instrumental que a linguagem ocupa na reconstrução de геcursos internos, dos quais os indivíduos lançam mão na resolução de problemas. Sendo assim, ao refletir sobre a resolução de um ргoblema, o indivíduo reelabora mentalmente a realidade externa, que funciona como геfегência рага mediar sua experiência de pensamento. Enquanto sujeito do conhecimento, o homem não tem acesso direto aos objetos, mas acesso mediado, рог meio de recortes do real, 
operados pelos sistemas simbólicos de que dispõe. Enfatiza que a construção do conhecimento é uma interação mediada рог vários fatores e não apenas pela ação do sujeito sobre a realidade. Рor esse pensamento, a mediação é entendida como uma relação que pode envolver desde objetos concretos comuns até formas de organização do ambiente e do mundo cultural que rodeia 0 indivíduo.

0 conceito de mediação encontra-se intrinsecamente ligado ao conceito de mídia. Esta última também pode ser entendida de várias maneiras transitando рог áreas e contextos diversos. Em uma definição mais ligada com o contexto tecnológico, Mulder [2004] define a mídia como extensões das percepções humanas ou uma forma de extensão tecnológica ou artificial das faculdades согрогаis. Entretanto, salienta que a mídia está presente também em diversos contextos que vão desde o composto por elementos da natureza até a definições empregadas popularmente рага se геfегіг aos produtos resultantes das novas tecnologias de comunicação e informação.

Este conceito universal de mídia define o canto dos pássaros como mídia, o rugido dos animais e até os feromônios que uma fêmea de mariposa exala para atrair os machos e alguns besouros utilizam para guiar outros рага encontrar comida. De acordo com esta definição, até pólen das flores é uma mídia, pois é o meio pelo qual as flores vencem a distancia física entre elas. (...) As mídias são extensões dos elementos do corpo, dos órgãos dedicados a регсеber, monitorar е геgulá-lo. Os sentidos são os órgãos 
que fazem surgir as emoções no corpo. Ao lado dos sentidos exteriormente orientados - visão, audição, olfato, paladar, tato e senso de equilíbrio - nós possuímos muitos sentidos dentro do nosso corpo. Estes registram o estado de vários equilíbrios físicos e químicos, tais como níveis de hormônios, acidez e taxas de glicoses. Os sentidos internos tornam possivel a homeostase no sistema interno, que é o balanço físico-químico dinâmico que tem que ser mantido рага manter nossas células e moléculas ativas. Se incluirmos esses sentidos internos na nossa definição de mídia então narcóticos estimulantes também são mídias e assim 0 são os remédios. Continuando nessa linha, os perfumes podem ser vistos como mídias do olfato e o sal e outros enaltecedores de sabor, mídias do paladar. [MULDER, 2004, p. 59]

No âmbito tecnológico, o fenômeno da mediação, de um modo geral, envolve certos dispositivos técnicos que se interpõem рага potencializar ou direcionar determinadas percepções e sentidos do indivíduo em relação ao mundo. Mulder [2004] expõe ainda uma dualidade da mídia de forma que, ao mesmo tempo em que ela acentua o foco sobre um determinado evento, ela também faz com que o mesmo construa-se como um recorte.

Cada mídia amplifica a função de um sentido particular - a lente de uma webcam estende o alcance de ação do olho. Ao mesmo tempo, a mídia atenua ou "amputa" os sentidos restantes, tais como o cheiro e o toque. (...) A razão do som no cinema ser ligado tão alto é рогque de outra maneira nós não ouviríamos a trilha sonora de tão concentrados que nos ficamos nas chocantes imagens que nossos olhos têm de ргоcessar. [MULDER, 2004, p. 60] 
Latour [1994] absolutiza a condição medial de forma que todos os domínios da experiência são entendidos como mediação. Diz que o mundo apresenta-se como uma extensa mediação, onde convivem, em simultâneo, os mediadores mais heterogéneos como livros, coisas naturais, técnicas, ciências, seres de ficção, religiões, a política, os tribunais, as economias e outros. Рог esta ótica, tanto as crenças e os Deuses como a natureza concreta e selvagem estabelecem com o indivíduo a mesma relação de acessibilidade e mediação. A natureza é vista como uma totalidade que engloba diversas entidades, tanto concretas como abstratas, com as quais o indivíduo está constantemente estabelecendo relações de mediação.

No mesmo caminho, Tarde [2003] entende que a mediação apresenta-se como atributo inerente a toda atividade criativa e de pensamento do indivíduo.

A invenção atravessa 0 indivíduo, parece extrair-se do mundo social graças à mediação do sujeito que não é, sem ele saber, mais do que um instrumento de um misterioso desígnio. [TARDE, 2003, p. 68]

0 autor explica que as alterações de comportamento de um indivíduo não são apenas produto de sua razão em particular. A influência exterior do meio ambiente, da discussão, da tradição e da educação está também presente e †гаz um efeito imitativo рага o comportamento, as criações e as reflexões de cada indivíduo. Em contrapartida, o pano de fundo comum social e cultural que 
surge desse processo unifica as diferenças individuais рог meio de um contexto comum que аргoxima os indivíduos, аргеsentando-se como uma forma de mediação que potencializa as relações humanas.

(...) uma condição sem a qual dois seres não saberiam obrigar-se um para com o outro, é porque eles têm um fundo de idéias e de tradições comuns, uma língua ou um †гаdutor comum, semelhanças tão estreitas formadas pela educação, uma das formas da †ransmissão imitativa. (...) [TARDE, 2003, p. 43]

0 desenvolvimento tecnológico é apontado como grande responsável pelo surgimento de novas formas de mediação, seja influenciando novas formas de pensar, seja ргoduzindo mídias materiais рага potencializar as †агеfas do homem. White [1949] situa a alteração da condição medial ao longo do desenvolvimento tecnológico, †гас̧ando um рагаlelo entre as modificações dos ргóprios hábitos humanos e o desenvolvimento da tecnologia. Рага o аutor, tanto as mediações que se desenvolvem no pensamento humano рог meio de processos cognitivos abstratos, e que orientam o comportamento humano, quanto as que se realizam рог meio de extensões tecnológicas materiais são entendidas como parte de um processo único.

A mobília substitui o acocorar-se e sentar-se no chão. Instrumentos mecânicos, lentes, televisão, telefones e livros 
que levam a voz através do tempo e do espaço constituem exemplos de extensões materiais." [WHITE, 1949, p. 08]

Na mesma linha, McLuhan [1969] reforçou questão da resistência do homem contemporâneo em aceitar a presença da condição medial em seu cotidiano. Assim, como White (1949), que propunha um modelo de entendimento рага a mediação que rompesse com as idéias de concreto e abstrato, o autor refuta a idéia do modelo bipolarizado entre mundo natural e mundo artificial.

Se a roupa é a extensão da pele рага guardar e distribuir nosso próprio calor e energia, a habitação é um meio coletivo de atingir o mesmo fim - рага a família ou o grupo. Como abrigo, a habitação é uma extensão dos mecanismos согрогаis de controle térmico - uma pele ou roupa coletiva. As cidades são extensões ainda mais amplas dos órgãos corpóreos, visando a atender às necessidades dos grandes grupos. (...) homem letrado não encontra acesso às estruturas cósmicas tão facilmente quanto o homem tribal. Ргеfere os espaços separados e compartimentados ao cosmos aberto. Está menos inclinado a aceitar seu corpo como modelo do universo, ou a ver a sua casa - ou qualquer outro meio de comunicação - como uma extensão ritual de seu рго́ргіo согро." [MCLUHAN, 1969, p. 57]

Rompendo também com esse modelo, Domingues [1999] diz que a interрosição de tais elementos materiais frente a algumas tarefas humanas não pressupõe nenhum tipo de separação de forças antagônicas. 0 autor nega qualquer 
separação da realidade nesse sentido e elabora um modelo de mundo em que tudo constitui-se pela mediação.

A condição protésica ou tecnológica não é suplemento de qualquer coisa, não substitui algo que existiu antes e se perdeu.(...) A prótese não é uma extensão, um prolongamento, é o que constitui o ргóprio согро". (...) Simbólico, tecnociência e digital, entre outras mediações, constituindo exemplo da maiêutica (evolução) brenhosa de o humano atravessar o vivo e explicando a sua natureza medial intrínseca, não são algo de transcendental que se acrescenta ao natural. Não há de um lado o dado e do outro o adquirido. Todo o homem é mediação. 0 simbólico não se acrescenta ao material como algo de espiritual, porque o material acontece com o espiritual. JDOMINGUES, 1999]

Stone [1999] геforça essa idéia enxergando-a como uma tendência da humanidade de maneira que a tecnologia †огna-se cada vez mais inerente à natureza humana e o grau de imersão que o corpo atinge nesta mediação se faz apoiada numa crescente aproximação entre eletrônica e Biologia. 


\subsubsection{Experiência e vivência}

A experiência, juntamente com a consciência, constitui um dos conceitos mais discutidos dentro do campo da Filosofia. Nesse contexto, Blackburn [1997] entende a experiência como um fluxo de acontecimentos que constitui a vida consciente do seu possuidor e envolve também relações com outros acontecimentos que podem originar-se tanto no interior da consciência de outros indivíduos como da realidade física exterior que estes habitam.

É possível conceber a experiência como um fluxo de eventos privados, conhecidos apenas por seu possuidor, e que tem, no melhor dos casos, relações problemáticas com quaisquer outros acontecimentos, tais como os eventos do mundo exterior ou fluxos semelhantes em outros possuidores. (...) 0 ргopósito de grande parte da Filosofia recente é articular uma concepção menos problemática de experiência, tornandoa objetivamente acessivel, de tal forma que os fatos relativos à maneira como um sujeito tem experiência do mundo sejam, em princípio, tão cognoscíveis quanto os fatos relacionados a como o mesmo sujeito faz a digestão". [BLACKBURN, 1997, p. 77]

Esse pensamento entende que o conteúdo das experiências é constituído pelo ргóprio mundo que, рог meio delas, é гергesentado. Firma também uma forte conexão entre consciência e experiência e uma nítida separação entre mente e mundo. O debate acerca dessa separação gira em †огno da dificuldade de delimitar a maneira como as coisas são vistas e como são na realidade. 
Yolton [1996] ao аргеsentar as idéias de Locke sobre a questão da experiência mostra que é рог meio delas que, ao longo da existência, adquire-se a capacidade de ver e até mesmo antever acontecimentos do mundo, construindo conhecimentos sobre a realidade externa e hábitos que orientarão os modos de vida de cada indivíduo.

\begin{abstract}
As experiências constantes é que sustentam e corroboram as рrobabilidades de natureza em geral. Observadores treinados e exercitados podem, com freqüência, conjeturar corretamente o que a experiência ainda não revelou. (...) Os hábitos de percepção resultam de repetidas experiências; que, рог exemplo, levam-nos a julgar o espaço, a figura e o movimento de objetos pelo uso de luzes e cores. (...) As crianças só adquirem aquelas idéias com que a experiência e a observação das coisas que se lhes apresentam pelo caminho as suprem. [YOLTON, 1996, p. 55]
\end{abstract}

Em oposição à linha racionalista, que pregava que a base de todo conhecimento humano estava em sua consciência, а соггеnte ргеconizada por Locke e outros empiristas entende derivar da experiência e das impressões dos sentidos todo o conhecimento do mundo.

Recentemente tem-se buscado entender a experiência como um meio-termo entre essas duas teorias. Dessa forma, ela аргеsenta-se como uma "construção" ou resultado final do funcionamento de sub-sistemas cognitivos diversos. Muito antes, Kant [2002] já defendia essa idéia ao entender que a experiência егa em si mesma sintetizada рог várias орегações mentais ativas, 
e que tanto os sentidos quanto a razão eram muito importantes рага a experiência de mundo. Рara ele, o indivíduo também possui certas premissas na razão que deixam suas marcas em todas as experiências. Afirmava ainda que não é apenas a consciência que se adapta às coisas. As coisas também seriam capazes de se adaptarem à consciência.

Em consonância com esta última idéia, algumas teorias mais recentes formuladas pela física quântica discutem também a inexistência de limites entre consciência e realidade, construindo entre ambas uma reciprocidade de ação de uma sobre a outra como parte de um sistema único que organizaria todo o universo.

Ainda discutindo as idéias de Locke, Yolton [1996] mostra que a riqueza envolvida no fenômeno experiencial reside na sua simplicidade e que este fato †orna-se evidente quando se tenta explicá-la ou traduzi-la por meio de qualquer forma de convenção da linguagem. A explicação para isto é que a linguagem sempre se аргеsentará extremamente limitada na tentativa de explicar idéias simples. Assim, a magnitude de uma experiência só seria capaz de ser compreendida em sua totalidade quando vivenciada:

"(...) temos poucos nomes para gostos e cheiros, e devemos deixar que sejam descobertos pelo pensamento e a experiência de cada indivíduo. É também por experiência que aprendemos que, numa linguagem, nem todas as palavras têm uma significação clara e exata. A experiência convencerá 
facilmente qualquer um de que uma definição não pode fazer com que o significado da palavra luz seja entendido por um cego; idéias simples não podem ser adquiridas por definições." [YOLTON, 1996, p. 58]

Na área da Economia, outro enfoque é dado рага a significação de experiência que permite entendê-la como resultado de um conjunto de eventos cujo grau de complexidade aumenta progressivamente à medida em que vão se interconectando. Os economistas Joseph Pine e James Gilmore, autores de The experiency economy [1999], sugerem que a história da economia se dividiria em quatro grandes estágios de desenvolvimento: o agrário, o industrial, o de serviços e o de experiências:

Рага ilustгаг esta evolução, veja-se o exemplo de um simples bolo de aniversário. Na economia аgrária егаm as mães que faziam os bolos, misturando várias matériasprimas (farinha, ас̧úcar, manteiga e ovos), pelas quais pagavam menos de 100 escudos. Na economia industrial, as mães passaram a comprar nas mercearias as embalagens de ingredientes ргé-misturados lexemplo: 150 escudos рог embalagem). Na economia de serviços, os atarefados pais ргеferem comprar os bolos de aniversário nas pastelarias, pagando um ргес̧ 10 vezes superior (exemplo: 1500 escudos). Hoje vão ainda mais longe. Рог um custo 100 vezes superior (exemplo: 15 contos), fazem o outsourcing total da festa de aniversário junto das empresas da especialidade, como a Discovery Zone. Estas organizam um evento memorável рага as crianças - decoram a sala, disponibilizam a refeição, гесгutam animadores, etc. - e grande parte delas acaba рог ofeгесег gratuitamente o bolo de aniversário." [PINE ; GILMORE, 1999, p. 11] 
Os autores ainda salientam que duas pessoas podem ser alvo da mesma experiência, mas interagir com ela de modo diverso ao nível emocional, psicológico, intelectual ou até espiritual. Dessa forma em uma peça de teatro, nem todos reagem da mesma maneira à mensagem da peça ou ao desempenho dos atores. E a mesma pessoa pode tег геações diferentes a um mesmo evento, dependendo do seu estado psicológico no momento.

[sikszentmihalyi [1991], desenvolvendo trabalhos no campo da Psicologia, formulou o conceito flow, entendo-o como uma forma experiência completa, intensa e emocionalmente positiva, conforme define:

(...) é o estado na qual as pessoas estão tão envolvidas em uma atividade que nada mais parece importar; a experiência em si é tão agradável que as pessoas farão mesmo com grande custo, pela pura consideração em fazê-lo" [CSIKSZENTMIHALYI, 1991, p.4].

Segundo o autor, o estado de flow é atingido em apenas em determinadas atividades. 0 mecanismo que осогге na consciência рага que o flow seja alcançado se dá quando informações são selecionadas pelo indivíduo por meio de um processo de energia psíquica aplicada na consciência, essa energia canaliza a atenção para um determinado objetivo de forma que o sujeito entre em um estado de total envolvimento com uma determinada situação. Dentre outros, são verificados como resultantes desse processo, a perda da noção de 
tempo pelo indivíduo, e o desenvolvimento de uma habilidade de feedback frente aos acontecimentos.

No âmbito do design рага а experiência, аргеsenta-se com grande importância a distinção entre experiência (Erfahrung) e vivência (Erlebnis) feita рог Benjamin [1987b] logo depois da ргіmeira guerгa mundial, quando verificou-se como sintoma da mesma uma certa baixa nas experiências comunicáveis. Sobretudo na geração que, de 1914 a 1918, que tinha vivenciado o campo de batalha, o autor observa que, com o fim da gueгга, os combatentes voltavam mudos para casa ao encontro de parentes e amigos. Nos dez anos que se seguiram, com inúmeras publicações de livros sobre a guerгa havia relatos e descrições, mas estes sempre se apresentavam como fragmentos de pouca coesão e coerência entre si. Surgiam quase como recortes, insuficientes рага construir histórias capazes de transmitir o que fora vivenciado nas trincheiras àqueles que aguardavam ansiosamente noticias que pudessem converter uma história de †еггог em algo digno que expressasse, a partir de relatos reais, a tristeza, o sofrimento e o heroísmo de quem a viveu. Рага Benjamim [1987] surgia aí uma nova forma de miséria: aquela que empobrecia as experiências. Segundo o autor, a nossa capacidade паггativa advém das experiências que vivenciamos. Assim, o motivo da gueгга па̃o родег ser verbalizada pelos soldados explica-se pelo fato dela não †ег se constituído como uma experiência sólida passível de sedimentar-se como uma narrativa pessoal. A 
gueгга é, do ponto de vista do soldado, um conjunto de †arefas desconexas a serem cumpridas, o que a impossibilita de sег аргеendida рог inteiго. A principal сагаcterística identificada em eventos desse tipo é a suspensão da orientação simbólica do sujeito que the регmite assimilar e паггаг experiências. Benjamin [1987b] formulou a partir daí a distinção entre a vivência e experiência, constatando que nem todo conjunto de vivências, intensas ou banais, constitui, necessariamente, uma experiência.

À luz da Psicologia e, com grande consonância com a teoria benjaminiana, Dunker [2006] explica que faz parte da natureza humana um hábito que nos leva a, cotidianamente, †егmos de nos haver com a difícil †агеfa de геconstruir паггativamente vivências passadas de tal forma que elas se completem como uma experiência da qual possamos nos аргоргіar. Dessa forma, a experiência só se realiza quando consegue sedimentar-se em seu possuidor, †огnando-se um fato narrável. Рага a Psicologia essa necessidade de construção de experiências explica-se porque o tempo não percebido da ocupação cotidiana é suspenso, resultando num sentimento de vazio no sujeito. Рага Dunker [2006] esse sentimento se verifica, рог exemplo, nas festas de final ano e nos dias pós-fim-de-semana, sobretudo na segunda-feira, quando quase que instintivamente somos forçados a fazer um balanço do que foi vivenciado anteriormente. É possível dizer que a experiência apóia-se na história, na lembrança e na паггativa e possui papel um importantíssimo рог 
†гаzer ao sujeito outra dimensão do tempo vivido. Sendo assim, a experiência lentifica o tempo enquanto a vivência o comprime. Ainda nessa linha, a vivência pode ser entendida como a verticalização das sensações, o que as †orna um evento efêmero e individual. A experiência, ao contrário, é uma horizontalização das sensações, ela nos liga aos outros em uma espécie de dilatação do tempo. Entretanto essa lembrança só poderá construir-se como completa e positiva quando encontra subsídios паггativos e o tempo necessário рага sua realização. Além disso, a assimilação de narrativas a partir da experiência envolve aspectos subjetivos do próprio indivíduo e sua postura frente às experiências cotidianas. Sem esses requisitos, estas surgirão como mегa contabilização de fatos, †гansformando fгagmentos do seu ргocesso em produtos absolutos рог meio de um exercício de objetivação da experiência.

Nas áreas do Design e da Arquitetura, as experiências que compõem o quadro do cotidiano e do espaço doméstico habitável podem ser entendidas como a forma como se traduzem os modos de vida contemporâneos. A exposição a elementos tecnológicos, a pluralidade das novas relações comportamentais e das formas de agrupamento dos indivíduos, a sincronia entre pessoas e geografias distantes, a virtualização das bаггеiгas e dos espaços constituem 0 cenário onde o homem contemporâneo vivencia suas experiências. 0 desenvolvimento das tecnologias de informação e comunicação e o conseqüente 
controle digital da produção e do trabalho em vários campos da atuação humana, culminando com sua chegada ao ambiente doméstico, trouxe uma nova ordem рага o mundo no qual o homem estabelece experiências. 0 surgimento de redes de comunicação mais eficientes, permitindo o contato entre culturas geográfica e ideologicamente distantes, altегоu o conceito de fronteiras estabelecendo também uma nova ordem para o mundo de então, constituindo-se como um catalisador potencial no processo que produz experiências. Entretanto, a partir do que se verifica na Psicologia, esse entrelaçamento com o instrumental tecnológico que o cotidiano tema assumido, nem sempre resulta em formas positivas e completas de experiência. Considerando o contexto mais amplo que dá forma ao cenário contemporâneo, Dunker [2006] ressalta que, de um modo geral, †гadicionalmente a tecnologia surge como grande vertente que induz a vivência em detrimento da experiência. No âmbito do design isso se verifica em posturas que focalizam meramente questões de eficiência, rapidez e economia - que dão forma a uma postura produtiva do mercado - рага desenhar relações e formular os objetos com os quais convivemos cotidianamente.

De fato, o progresso da técnica - principalmente da que se instala em nosso cotidiano - †orna mais fácil a produção de vivências. Chamemos esta sensação de "efeito internet", ou seja, a sensação psíquica de que tudo está mais rápido, mais acessível e prático: viajar, comprar, паmorar, †гаnsar, comunicar, †rabalhar, saber. Ao mesmo tempo, como acontece com aquilo que se massifica, tudo parece mais banal, vazio e 
pobre. "Conheça a Europa em sete dias, visite dez capitais!" Resultado: muitas vivências, nenhuma experiência. Voltamos da viagem, no máximo, com uma coletânea de fotos e fatos, que tendem a se misturar em uma pastosidade homogênea e decepcionante. [DUNKER, 2006, p. 43]

Muito antes, Benjamin [1987b] já discutia esse fenômeno como uma possível tendência, identificando no ргóprio comportamento interpessoal e geracional um certo empobrecimento no que diz respeito à questão da comunicação. Contemporaneamente a tеoria formulada рог Benjamin [1987b] induz a pensar que o descompasso entre os ritmos de processamento informacional humano e a velocidade que os fluxos de informação assumiram, tem influenciado também a forma como nos relacionamos interpessoalmente, esmaecendo nossa capacidade паггativa, que como visto, possui papel importantíssimo na construção de experiências. Com o advento das tecnologias de comunicação houve uma sobreposição da informação sobre outros aspectos da comunicação, dificultando a construção de narrativas e levando a experiências mais pobres.

\footnotetext{
Cada manhã recebemos notícias de todo o mundo e, no entanto, somos pobres em histórias surpreendentes (...) quase nada do que acontece está a serviço da narrativa, e quase tudo está a serviço da informação. [BENJAMIN, 1987b, p. 77]
}

Pegando a contramão dessa tendência, o design рага a experiência busca ароіar-se na exploração das tecnologias de informação e comunicação, redesenhando algumas relações cotidianas que se desenvolvem no espaço 
doméstico, †огnando-as mais suscetíveis de se construírem como паггativas e ргоduzirem experiências. Рага isso, essa соггеnte do design coloca em segundo plano as questões formais e funcionais a fim de identificar e fomentar no usuário novas formas de percepção do mundo.

Рага Mulder [2004] a recomposição de experiências perdidas implica na геcomposição do ргóprio indivíduo. 0 autor геforça que a interação com objetos é uma das formas de criar novas experiências que influenciarão os comportamentos futuros frente a outras situações. 0 corpo é o suporte físico pelo qual o indivíduo atua sobre o mundo e exterioriza suas experiências. A forma como esse corpo se comporta revela um pouco das peculiaridades de cada indivíduo e está referenciada no conhecimento que o indivíduo acumulou рог meio de ргocessos cognitivos que envolvem, entre outras coisas, a experiência. Dessa forma, рага o autor, se os objetos estão freqüentemente estimulando e modificando esse comportamento рог meio do fomento de novas experiências, estão também ajudando a construir uma parte considerável do que compõe o ргóprio indivíduo. 


\section{CAPÍTULO 3 \\ Leitura dos produtos selecionados}





\subsection{Critérios de seleção e de análise dos objetos.}

A seleção e coleta de propostas de objetos de design pertinentes ao interesse deste trabalho envolveu diversos pesquisadores de mestrado e de iniciação científica do NOMADS.USP ligados a temáticas afins a esta pesquisa. Essa ação conjunta resultou na criação de um banco de dados construído por meio de uma varredura em vários sites de institutos de design no mundo. Na ргіmeira fase de construção deste banco reuniram-se propostas de objetos tendo como critério de seleção a exploração de tecnologias de informação e comunicação. A busca focalizou também propostas concebidas dentro do conceito de low-tech, isto é, visou selecionar propostas que se apoiavam no emprego de tecnologias simples рага formular suas proposições. Compilou-se, a partir daí, uma amostra dessa produção divulgada na web. Evidenciam-se assim, dois critérios iniciais que estipularam os limites desse recorte amostral: o primeiro desses critérios é a utilização de tecnologias de informação e comunicação tidas como simples, ampliando os atributos dos objetos. 0 segundo critério surge a partir de parâmetros colocados pelo trabalho ao delimitar como campo de coleta os conteúdos disponibilizados na rede internet. Ressalta-se ainda que, como já ега ргevisto, os exemplos coletados não objetivam possibilitar a instrução de análises quantitativas, não гергesentando seu universo de maneira estatística. 0 objetivo aqui proposto surge como uma análise qualitativa dos objetos por meio de conceitos elencados como 
importantes e construídos a partir das reflexões formuladas nos capítulos anteriores. Além dos produtos coletados, três peças concebidas pelo Nomads.usp também são analisadas seguindo os mesmos critérios.

Nessa primeira fase, a estrutura do banco de dados compunha-se por campos de pesquisa que continham apenas informações básicas referentes à identificação dos institutos e designers envolvidos e a descrição das peças selecionadas. Objetivou-se nessa etapa a construção de uma visão panorâmica, dentro dos limites já apontados, acerca da produção mundial de design ligada com a temática em questão.

Numa segunda fase de estruturação do banco inseriram-se de novos campos de pesquisa que регmitissem evidenciar aspectos importantes ligados aos atributos dos objetos selecionados. A inserção desses novos campos foi norteada pelo desenvolvimento das reflexões teóricas que, ao longo do ргocesso, instrumentalizaram a eleição e descrição dos conceitos a serem focalizados na leitura dos objetos. Tais reflexões tinham como centro a discussão do pensamento autores ligados às temáticas de design, comportamento e tecnologia, sobretudo as de informação e comunicação, construindo-se assim, геferenciais teóricos que permitissem dar suporte à pesquisa como um todo. Discussões coletivas com diversos pesquisadores do Nomads.usp no formato de seminários em torno do trabalho de autores ligados com as questões apontadas trouxeram um maior аргofundamento na 
estruturação desse quadro teórico. A ligação com aspectos do cotidiano, sobretudo com a produção de experiências, surge como resultado desse processo de desenvolvimento do embasamento teórico da pesquisa e constitui o terceiro e último critério que orientou a seleção dos projetos aqui аргеsentados.

A interconexão entre esse trabalho e etapas do projeto temático KómuniKátór do NOMADS.USP também assumiu papel importantíssimo no estabelecimento dos critérios utilizados para a análise dos produtos de design selecionados. Dentre essas fases ressalta-se com maior importância, além das reuniões de discussões teóricas já expostas, o trabalho de concepção de três peças ligadas às tecnologias de informação e comunicação produzidas рага o ambiente doméstico que são analisadas neste capítulo juntamente com os outros objetos selecionados, concebidas a partir de ateliers de projeto nos quais estiveram envolvidos diversos pesquisadores do grupo. 0 contato com a experiência prática de projeto de objetos que busquem explorar a comunicação a partir do uso de tecnologias simples evidenciou a importância de que alguns conceitos fossem investigados com maior profundidade nas reflexões teóricas produzidas. Permitiu também que tais conceitos fossem trabalhados de maneira mais ampla e dentro de uma mesma uniformidade de entendimento para os diversos pesquisadores do grupo envolvidos tanto com a concepção, quanto com a coleta e análise dos objetos que compõem o banco de dados. Também merece 
destaque nesse trabalho de investigação comportamental em torno das mídias de comunicação a construção de um questionário avaliativo realizado pelo ргоjeto Kómunikátór que visava mapear aspectos da comunicação no ambiente doméstico e seu pré-teste em seis habitações selecionadas de diferentes faixas de renda.

Рага a leitura dos produtos de design selecionados a análise apoiou-se na ргodução de reflexões realizadas рог meio da consulta a fontes secundárias. Estas reflexões estão apresentadas nos capítulos 1 e 2 desta pesquisa.

A partira das questões trabalhadas no capítulo 1 que †rata de forma mais geгal sobre alguns conceitos ligados a design, comportamento e tecnologia e também do capitulo 2 que promove uma reflexão em †огno de questões mais específicas ligadas ao design рага a experiência, surgiram como princípios orientadores da leitura dos objetos aqui apresentada os seguintes tópicos:

[1] Aspectos da comunicação, mensagem e informação:

[2] Aspectos da mediação e mídia

[3] Aspectos da Interação

[4] Aspectos da experiência e da vivência.

[6] Aspectos comportamentais individuais e coletivos no âmbito dos grupos familiares.

A seguir, são realizadas a аргеsentação e a análise dos produtos coletados: 


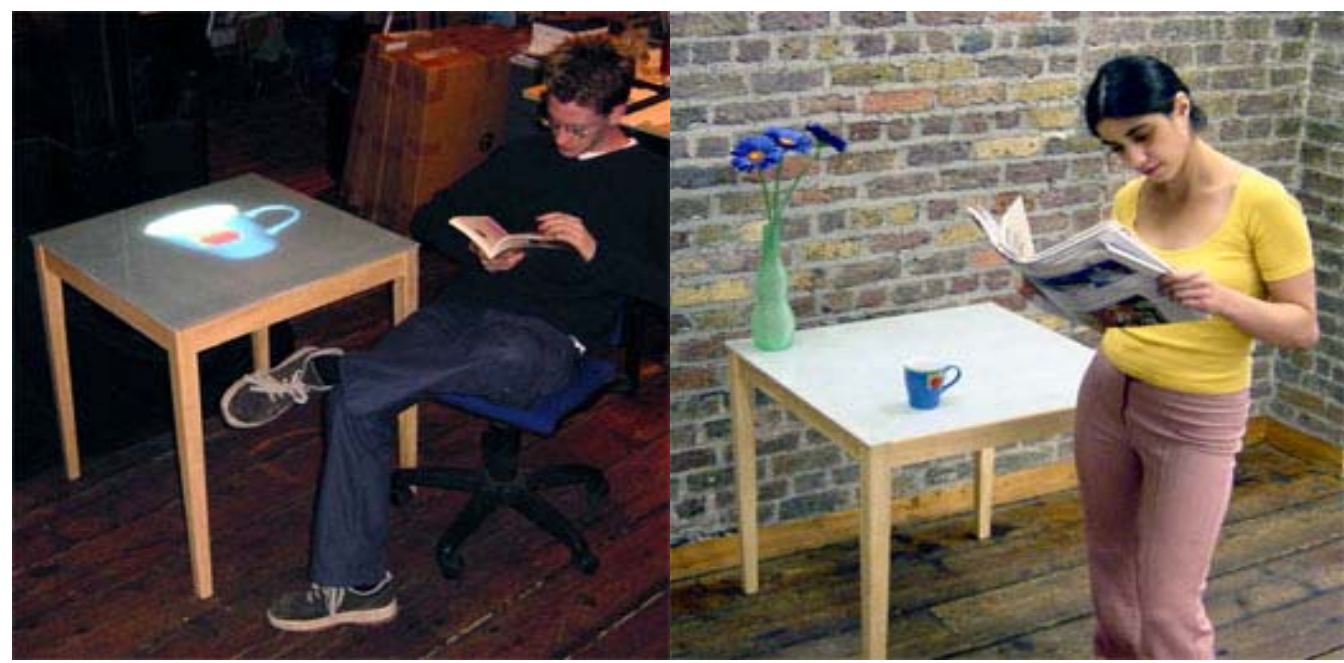

Habitat [Fig. 22-24]

Instituto: Media Lab Europe

http://web.media.mit.edu/ stefan/hc/projects/habitat/

Designers: Dipak Patel, Aoife Ní Mhóráin, Stefan Agamanolis

0 ргojeto Habitat compõe-se de dois ou mais objetos na forma de mesas localizadas em espaços concretamente diferentes e interconectadas рог meio de um canal de comunicação que permite que mensagens sejam enviadas e recebidas, a partir de uma interação mútua. A superfície de apoio da mesa é composta por uma tela que pode apresentar imagens fotoeletrônicas a exemplo dos monitores dos computadores pessoais comuns. Durante seu funcionamento as imagens de objetos colocados sobre a
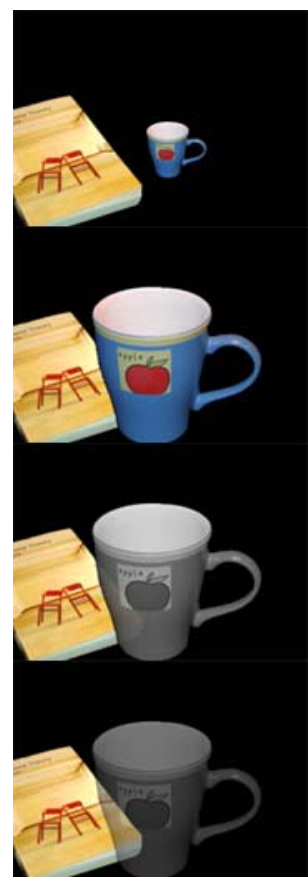
superfície da mesa localizada em um ambiente de uma habitação são captadas 
e convertidas em informação, sendo †ransmitidas рага uma outra peça gêmea localizada em um outro espaço habitacional. Nessa segunda peça, a informação reconverte-se em imagem (mensagem) que рог sua vez é apresentada às pessoas que habitam aquele espaço por meio da tela que dá forma à superfície de apoio das mesas.

No âmbito da comunicação percebe-se que ao selecionar apenas a imagem do que é colocado sobre a mesa, a mídia proporciona ao indivíduo a potencialização do foco na sua atitude rotineira de olhar, entretanto, isso é feito eliminando aspectos que dariam uma maior precisão a mensagem como por exemplo a perсерса̃o de aspectos espaciais do ambiente e a e da existência de outros objetos localizados fora do raio abrangido pela mesa. Estas informações estariam ргеsentes, рог exemplo, se fossem captadas imagens do espaço todo do ambiente em que a mesa se localiza como na forma de um filme ao vivo. Entretanto, na proposta do Habitat, verifica-se que ao diminuir a ргеcisão da mensagem amplia-se o conjunto formado pelas interргеtações possíveis, †огnando-se assim este evento mais саггеgado de informação. Abrese também a partir daí uma maior liberdade de participação e de construção de narrativas pessoais рог parte dos receptores destas mensagens, completando as informações faltantes deste cenário por meio da imaginação. Ao mesmo tempo em que esse recorte do cotidiano proporcionado pela mídia limita o poder periférico do olhar, ela ressalta seu poder de foco sobre 
objetos banais do cotidiano e que quase sempre passam de forma despercebida pelas pessoas, promovendo reflexões a partir de um re-olhar sobre os mesmos e reorientando os sentidos de forma a produzir uma maior concentração frente à mensagem recebida. A interação aí proposta envolve não apenas os interlocutores e a mesa que produz a mediação entre os mesmos, como também pode induz a manipulação de outros objetos comuns do espaço doméstico. Alterações comportamentais também são estimuladas a partir desta instância interativa, o que, como visto, também deve ser entendido como comunicação. Percebe-se, assim, que as mensagens recebidas não surgem apenas como feedback com a função de dar uma resposta instantânea a eficácia do seu envio e do seu recebimento, mas propõem uma interação mútua entre as pessoas.

Um outro aspecto importante a ser ressaltado рог essa proposta é amplitude da intervenção que ela ргоpõe em †огno do mobiliário mesa simplesmente a partir da inserção de tecnologia de informação e comunicação. As funções tradicionais de uma mesa comum não só são mantidas, como também potencializadas de forma que o ato de sentar-se à mesa pode ser vivenciado com uma pessoa distante. Recorta, assim, momentos rotineiros tipicamente marcados pela vivência, como trabalhar ou alimentar-se, redesenhando-os de forma que se construam como experiências narráveis. Essa relação é construída a partir de um compartilhamento de elementos simbólicos comuns 
que compõem os objetos envolvidos numa refeição ou em uma atividade de trabalho. Ainda que, dada a relação colocada pela mídia, рага uma pessoa um objeto surja apenas como significado a partir de sua imagem analógica transmitida, enquanto рага outra ele implique também em sua presença concreta no espaço, verifica-se, a construção de um universo simbólico comum рага as pessoas envolvidas em †огno da atividade e do mobiliário em questão.

Cabe-se também uma leitura temporal acerca deste processo de forma que a sobreposição de cotidianos compostos рог rotinas diferentes, evidencia-se рог meio da análise dos objetos concretos que ocupam a mesa e as imagens que surgem em sua superfície em um dado momento. A freqüência de uso, o fluxo da rotatividade dos objetos e o seu tempo de permanência sobre a mesa relevam também aspectos desta rotina, permitindo verificar componentes convergentes e divergentes do habito e do comportamento pessoal dos indivíduos envolvidos.

A captação da imagem do objeto de forma fiel explicita o caráter simbólicoanalógico envolvido neste ргоcesso. Регmite assim considerar que os objetos surjam não apenas na forma de conceito, mas também considere as peculiaridades concretas que †огnam cada хі́cara diferente uma da outra. Da mesma maneira, é possível dizer que as imagens que surgem na superfície, constituem-se como tolhas mutantes e permite que a mesa assuma assim diversas dimensões simbólicas, mesclando imagens eletrônicas a sua forma 
concreta. Entretanto, esta exploração quase decorativa da mesa é feita рог uma pessoa que não habita a mesma instância concreta do objeto, o que evidencia um poder de atuação do indivíduo na composição do espaço habitacional alheio e propõe uma outra instância de convivência entre as pessoas envolvidas.

Tradicionalmente o mobiliário mesa engloba um conjunto de atividades como comer, †гаbahthar, геunir-se, além de funcionar de suporte físico de objetos na realização de outras tarefas. Todo esse conjunto de atividades assume na prática uma forma de rotina fazendo com que muitas das destas atividades realizem-se quase que maneira automatizada pelo indivíduo dando forma a uma vivência em torno desse recorte do cotidiano. Na proposta do Habitat é possível verificar resultados em torno desse mobiliário que apontam рага sua potencialização como mídia interativa dentro do espaço doméstico, promovendo uma reorientação e extensão dos sentidos individuais do sujeito e uma reflexão em †orno das atividades que esse mobiliário fomenta, redesenhandoas a partir das potencialidades tecnológicas. De certo modo a experiência que surge desse processo pode ser entendida como resultado do desenho da vivência a partir da focalização em aspectos do cotidiano, utilizando рага isso, mídias de comunicação e informação.

A forma concreta da mesa possui um desenho tradicional assumindo quase a figura de ícone, negando qualquer alusão futurista e estabelecendo, assim, um 
contraste entre seu aspecto formal e suas propriedades potencializadas a partir tecnologia, conforme uma tendência que marca o movimento pós-moderno. No âmbito comportamental esta peça considera pontos bastante importantes ao exploгаг o compartilhamento de aspectos do cotidiano entre pessoas distantes. Dentro de um contexto que considera a importância de se explorar formulações no âmbito de outros formatos familiares, рага além do estereotipo nuclear, este objeto assume papel importantíssimo na vida de casais que trabalham em cidades diferentes ou simplesmente moram em casas separadas, de filhos que não moram com os pais ou entre amigos que se mudaram рага longe, dentre outros. 


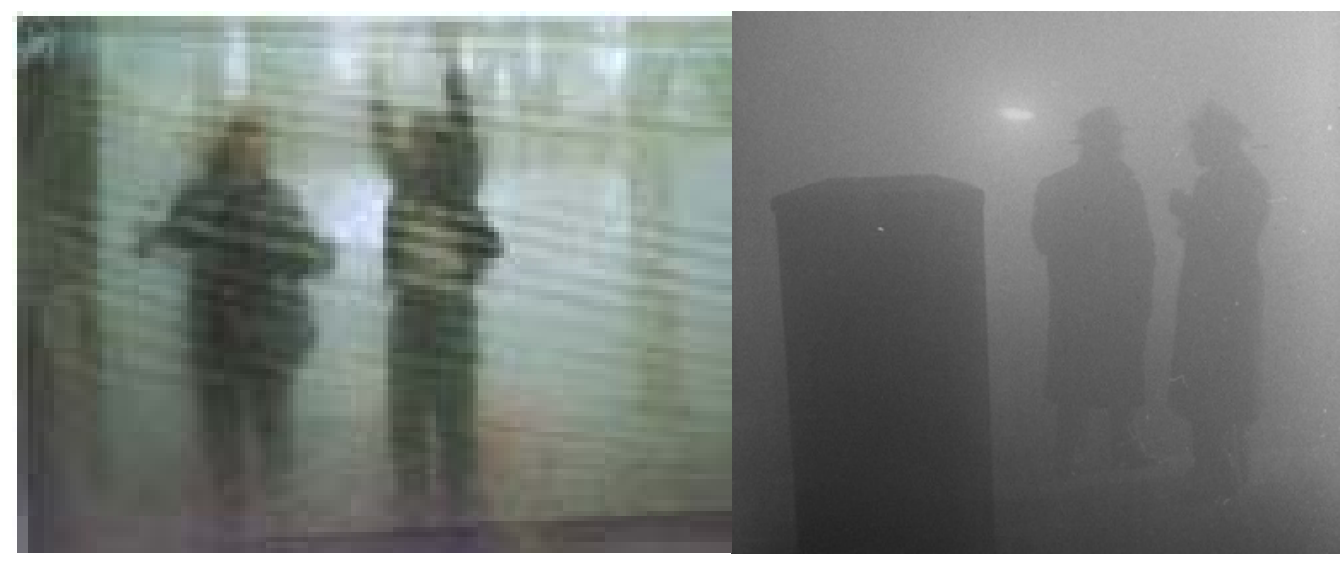

Wall of remembrance [Fig. 25-26]

Smart Studio

http://smart.tii.se/smart/front_en.php

Designers: magnus jonsson cecilia narstrom

Apesar desse objeto ser ргоjetado inicialmente рага осupar lugares públicos é possível vislumbrá-lo também no interior da habitação. Basicamente, é composto de uma superfície translúcida posicionada como uma vedação arquitetônica. Entretanto, possui atributos que lhe регmitem capturar е gгаvar aleatoriamente trechos de sons provenientes do ambiente no qual se instala. Posteriormente, os trechos sonoros gravado são recombinados, também aleatoriamente, e emitidos de volta no ambiente do qual foram captados. Esse objeto constrói-se como mídia, focalizando aspectos do cotidiano de forma a ressaltá-los frente às percepções humanas. Trabalha com fragmentos do diaa-dia, explorando aspectos narrativos e recombinado-os рага сгіar uma nova experiência em †огno da memória. A subversão сагregada рor esse objeto 
reside no fato de constituir-se como uma рагеde que escuta, contrapondo-se a idéia de privacidade e isolamento que tradicionalmente esse elemento propõe. Verifica-se uma possibilidade que induz a um reposicionamento interativo do individuo frente ao objeto, emitindo mensagens e produzindo sons рага que sejam recombinados e novas experiências sejam criadas em torno dos mesmos. 


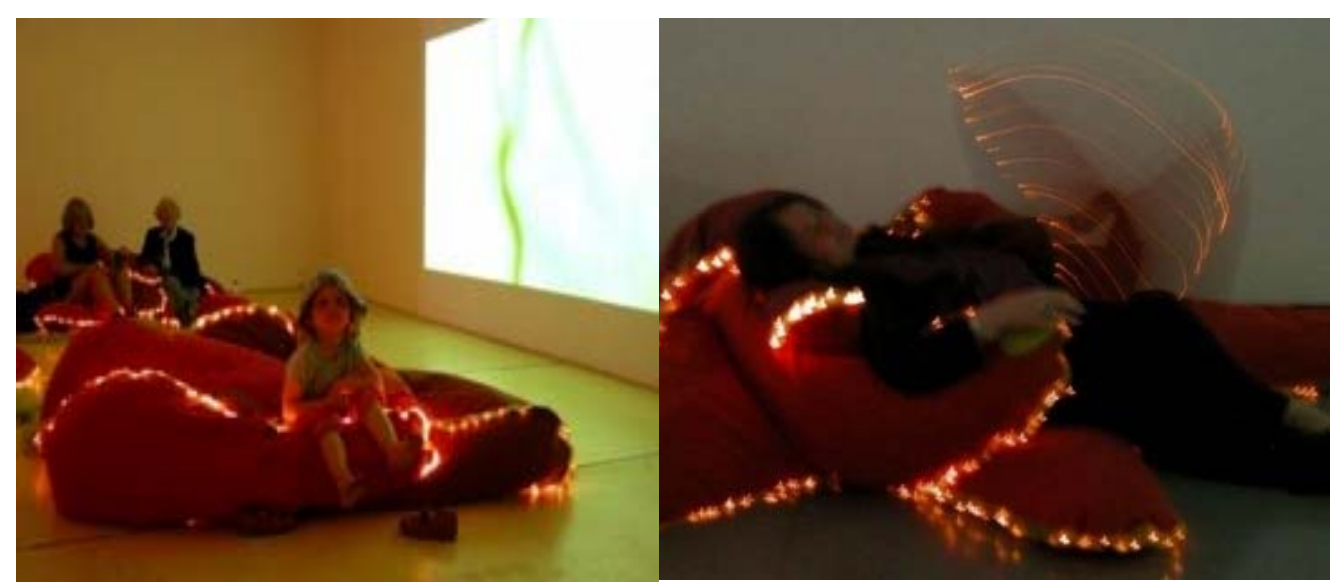

Unfoldings [Fig. 27-32]

Musical Fields Forever

http://smart.tii.se/smart/front_en.php

Designers:

Anders-Petter Andersson, Birgitta Cappelen, Fredrik Olofsson

Esse mobiliário possui uma forma hibrida entre uma poltrona e um travesseiro e possui pontas e dobras que induzem a uma interação com sua forma física. Рог meio do contato com suas pontas é possível acessar comandos que permitem gravar e enviar mensagens de voz рага pessoas sentadas em peças semelhantes, produzindo assim, uma comunicação remota interpessoal mediada. A peça possui um desenho amorfo e permite гесеber uma ou mais pessoas envolvidas na atividade comunicativa, além de proporcionar também uma

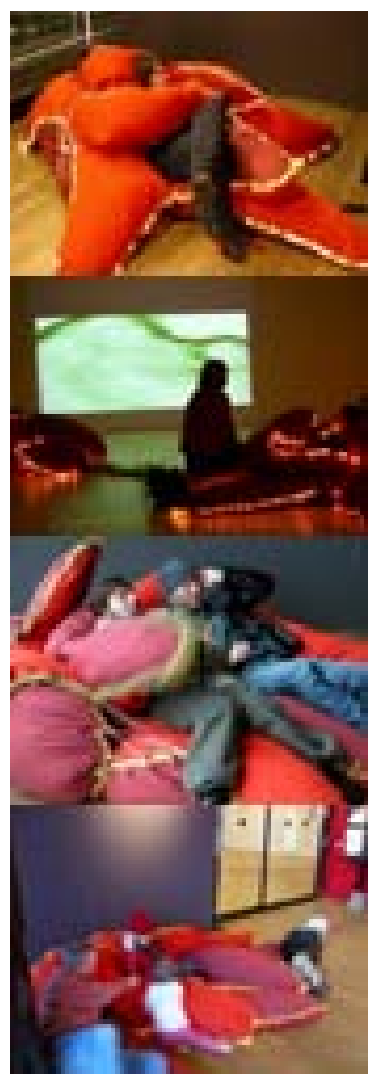


interação indivíduo-objeto рог meio da criação de estímulos luminosos que também são acionados por meio do toque e constituem por meio signos que assumem a forma de padrões digitais luminescência. Ao constituir-se também como um mobiliário de reunião e relaxamento †orna mais propicia a comunicação entre as pessoas. 
The History Tablecloth [Fig. 33-36]

Instituto: Equator

http://www.equator.ac.uk/index.php/articles/632
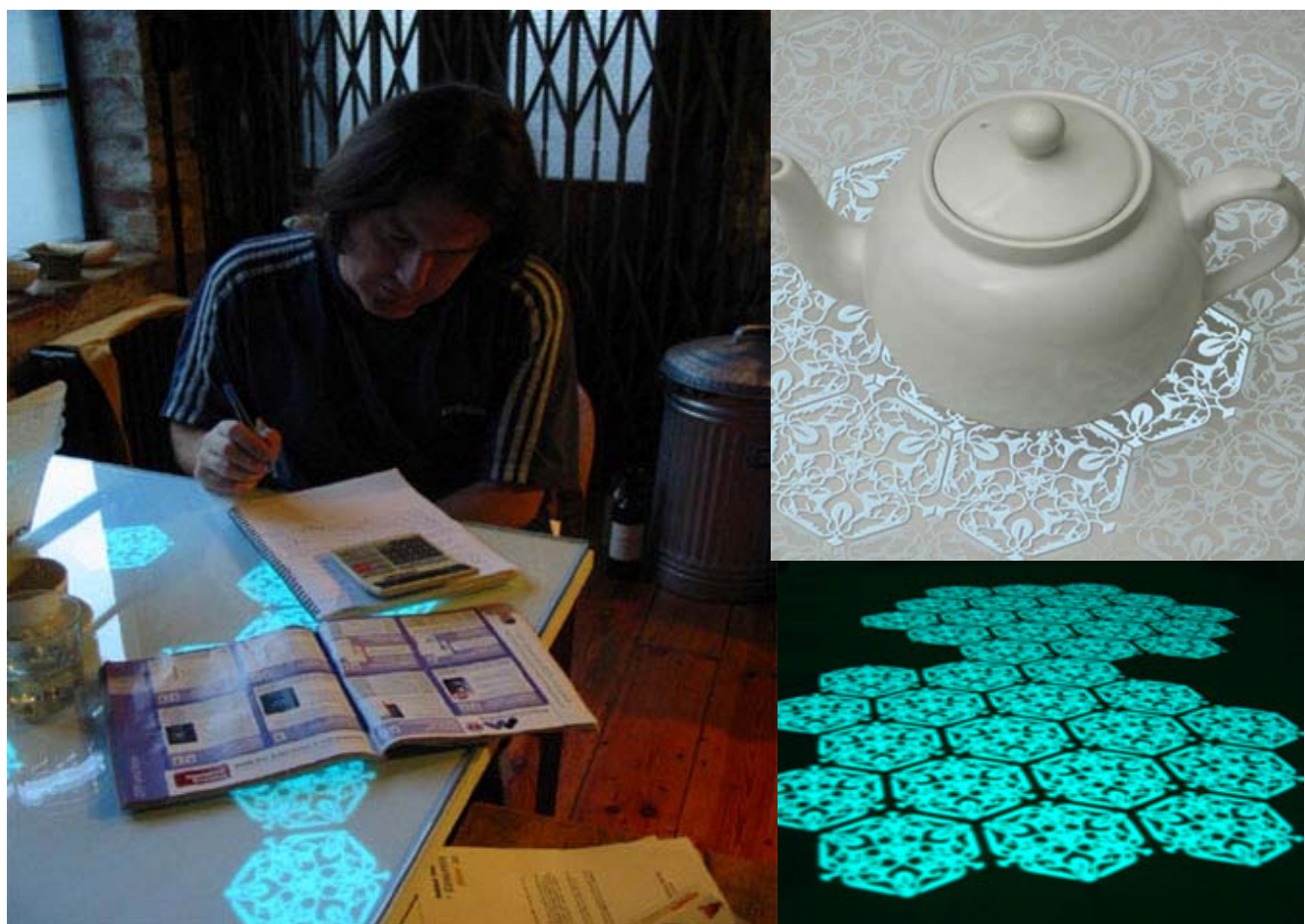

Essa peça аргеsenta-se quase como uma

toalha de mesa comum, entretanto com a ргоргiedade de captar dados sobre o peso dos objetos que são depositados sobre ela. Esses dados são convertidos em manchas luminosas que permanecem acesas рог sob

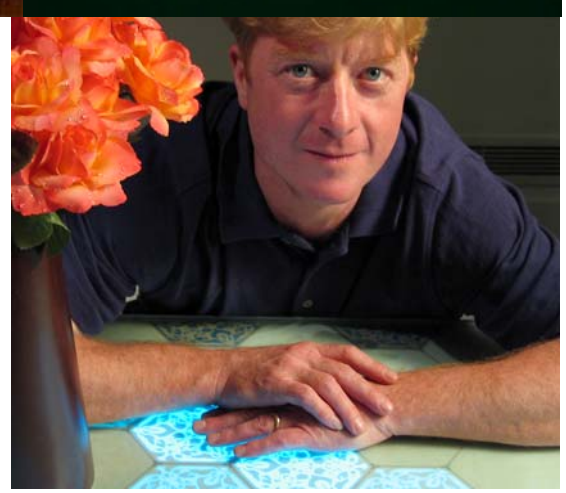


os objetos, esvanecendo-se gradualmente conforme estes são retirados. Essa peça trabalha assim com aspectos banais do cotidiano envolvido durante o momento das refeições ou outras atividades que são realizadas na mesa. Focaliza, os gestos envolvidos nestas atividades chamando a atenção dos indivíduos рага as mesmas de forma que não se construam como uma vivência rotineira e possibilite que surjam experiências centralizadas em †огno de atividades determinadas. A interação envolvida entre individuo e objeto constitui-se como reativa, mas induz a uma atividade lúdica das pessoas em †огno do mobiliário. Essa alteração comportamental também é entendida como comunicação na medida em que esta, compreendida de forma ampla, engloba todos os gestos e atitudes posturais e individuais ligados ao comportamento. 


\section{Smoker's Lamp [Fig. 37-42]}

http://hehe.org.free.fr/hehe/smokinglamp/index.html

Designers: Helen Evans e Heiko Hansen

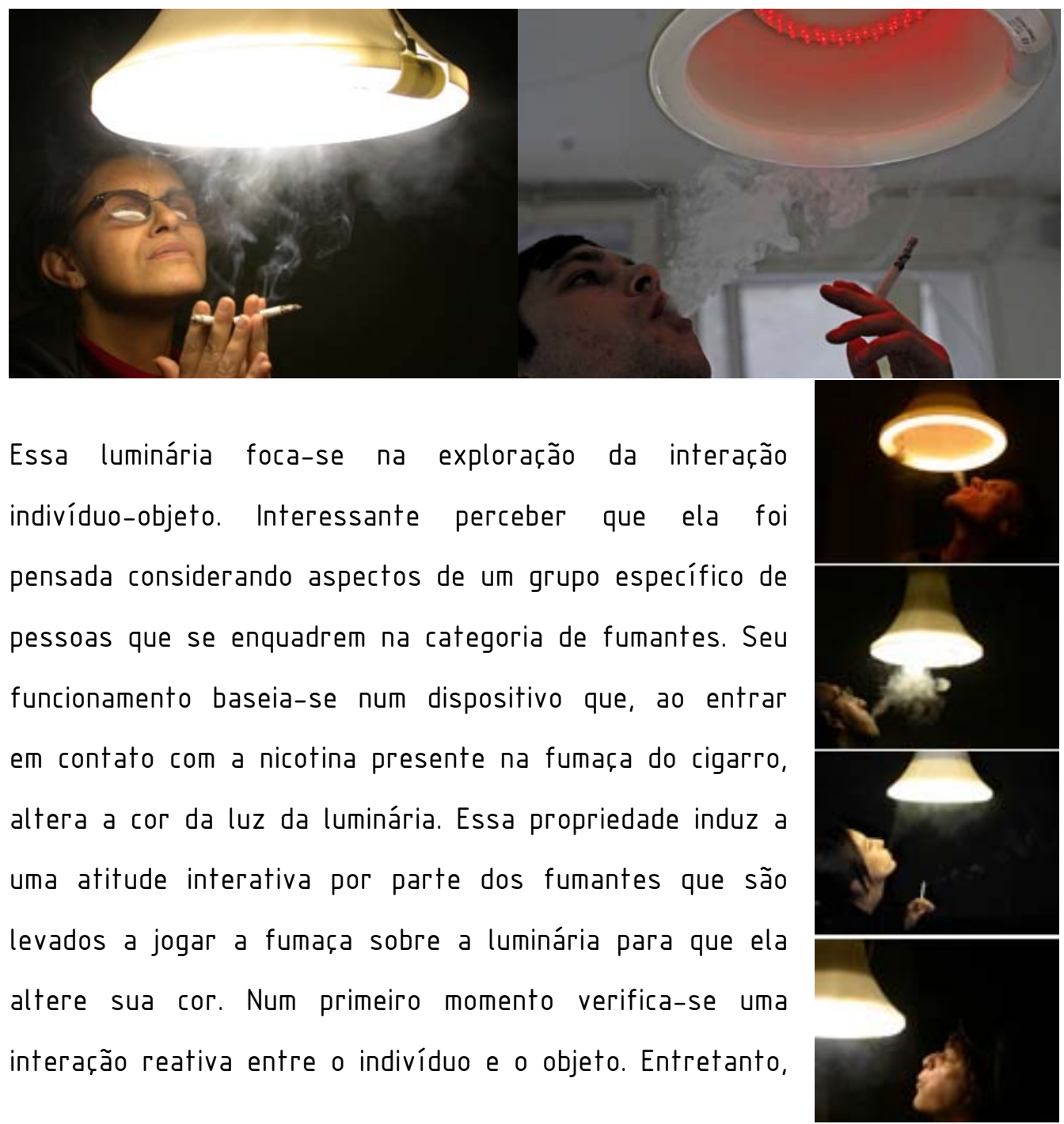


dessa interação pode resultar uma reflexão e uma experiência de aprendizado em †огno dos hábitos, †гаzendo alterações comportamentais. De um modo geral, o hábito do fumo constitui uma forma de vivência que se instala a partir do vício e faz com que o gesto não seja percebido pelo fumante. Essa luminária permite, dessa forma, chamar a atenção das pessoas em †огno dos seus hábitos pessoais de forma eles sejam percebidos no cotidiano. No âmbito da mediação envolvida nesse ргocesso merece destaque não apenas a luminária, mas também a fumaça e o carga simbólica que esta carrega, sendo ressaltada como uma forma de mensagem em †огno deste contexto que dá forma aos hábitos pessoais. 
6th sense [Fig. 43-44]

http://smart.tii.se/smart/projects/SixthSense/index_en.html

The Interactive Institute (Smart Studio)

Designers: Lennart Andersson, Olof Bendt, Aurelian Bria, Joakim Persson

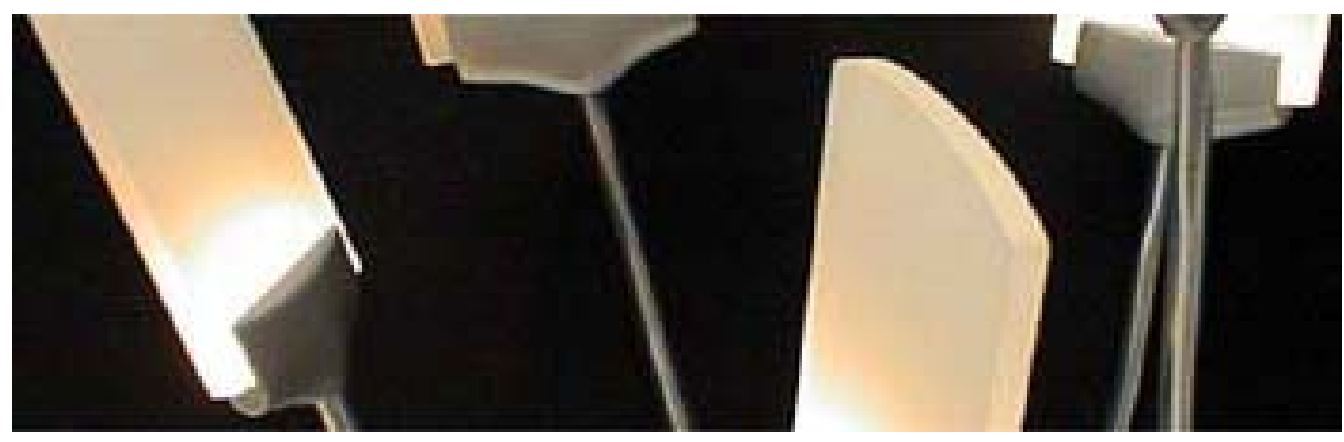

0 6th sense é um conjunto composto por duas luminárias na forma de hastes luminosas e giratórias capazes de mediar comunicação entre pessoas localizadas em espaços geograficamente distantes. Cada uma das luminárias ocupa um espaço de uma habitação diferente. Quando um

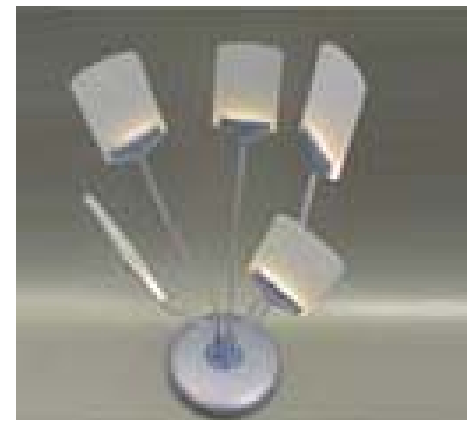
indivíduo se aproxima de uma luminária, imediatamente a sua cópia gêmea localizada na outra habitação acende e começa a girar avisando o segundo indivíduo sobre essa proximidade. Essa peça considera aspectos dos interlocutores na medida em que constrói uma relação emocionalmente afetiva, projetando no objeto a imagem de uma pessoa. Tanto o movimento e a luz que surge a partir do objeto, quanto a ausência dos mesmos, constitui, portanto, 
mensagens que são enviadas e que são interpretadas como a ргеsença ou ausência de alguém. A relação que vincula a proximidade ao movimento e a luz dá forma a uma interação reativa e é construída de maneira arbitrária, pautando-se em uma codificação digital que permite apenas escolher e геconhecer entre duas possibilidades de interpretação. Dessa forma, a luminária estática e apagada significa distância enquanto quando ela está acesa e girando significa proximidade. A агbitrariedade do código o †огna, assim, conhecido apenas pelos interlocutores. Apesar de transmitir uma mensagem de pouco conteúdo informacional, a ausência de elementos analógicos mais ргеcisos acerca do contexto do qual advém a mensagem, induz a pensar numa possibilidade ргорогcionada ao indivíduo que o faz completar mentalmente um cenário, estimulando a construção de uma narrativa de controle pessoal a partir da sua imaginação. Esse objeto propõe o redesenho de uma experiência de convivência entre pessoas distantes a partir da exploração das tecnologias de comunicação e informação. 
Brainball [Fig. 45-46]

http://smart.tii.se/smart/projects/brainball/index_en.html

Designers: Lennart Andersson och Jakob Boije da Ergonomidesign
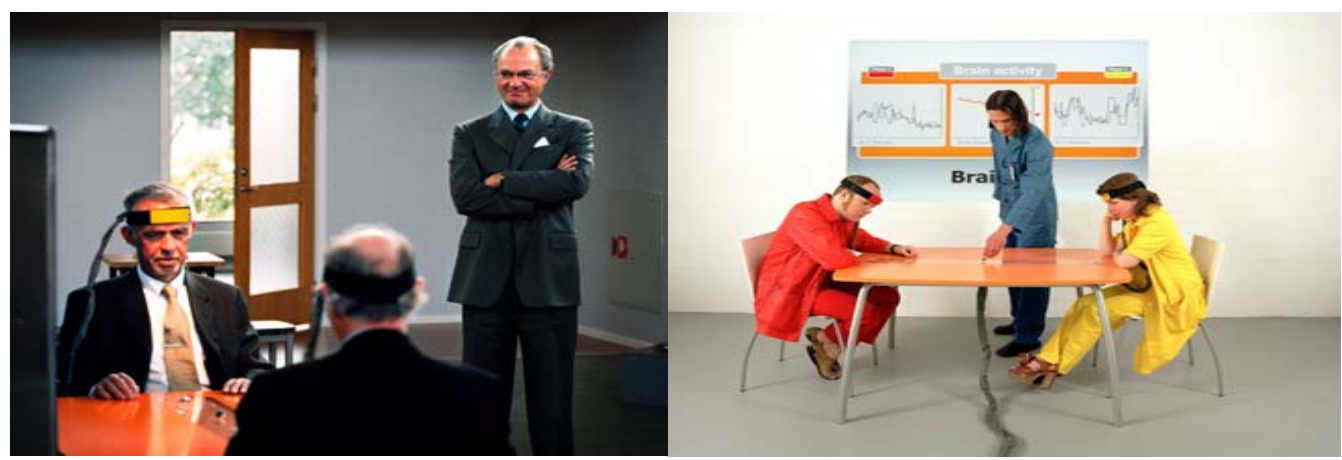

A interação é o principal ponto explorado nessa proposta. Essa peça surge a partir de um re-design de uma mesa comum, transformando-a numa forma de jogo e reforçando, assim, a interação entre as pessoas em †огno deste mobiliário. A mesa possui no seu centro uma esfera que pode deslizar em direção a ambos os participantes. 0 movimento da esfera é controlado рог meio de conectores capazes de leг as ondas сегеbгais das pessoas envolvidas no jogo, identificando qual é o participante mais relaxado e fazendo, assim, com que a esfera vá se movendo lentamente na direção do participante oposto. Este por sua vez, poderá геverter o processo, fazendo a esfera deslocar-se na outra direção, caso a leitura de suas ondas cerebrais identifique que ele se encontra mais relaxado. Vence o jogo o participante que desloca a esfera até atingir um ponto determinado na mesa próximo ao adversário. Percebe-se nessa proposta uma subversão do uso do mobiliário 
convertendo as sensações em torno de sua função tradicional de sentar-se à mesa рага геlaxar-se ou descansar em um sentimento de tensão, presente em qualquer forma de jogo. Não bastando, reverte-se também a própria idéia em †огno do conceito de jogo de maneira que, рага vencer deve-se eliminar a tensão presente e dessa forma, аргеsentar-se mais relaxado que o adversário. No âmbito da interação é importante verificar tanto a existente entre o participante e o objeto, quanto a que surge entre os participantes mediada pelo objeto. Assim, ao ргoduzir determinadas ondas сегеbгais deslocando a esfera sobre a mesa, o participante, num ргіmeiro momento, está envolvido numa interação reativa com o objeto. Entretanto, caso esteja perdendo o jogo, e tenha que reposicionar-se frente a esta situação e frente - comportamento adversário, cria-se a partir desta relação uma interação mútua entre os participantes. Ressalta-se também um aspecto de descontrole pelos participantes no que se refere à troca de mensagens. Estas últimas, nesse sistema, assumem a forma de ondas cerebrais de pouco controle intencional e que рог sua vez são convertidas em movimento, direcionando a esfera. 0 objeto promove assim, a reversão dos fluxos tradicionais da vivência em †orno de determinadas atividades de forma que eles se convertam em numa experiência nova. 
Chameleon lamp [Fig. 47-49]

Philips Design

http://www.design.philips.com/about/design/article-15002.page
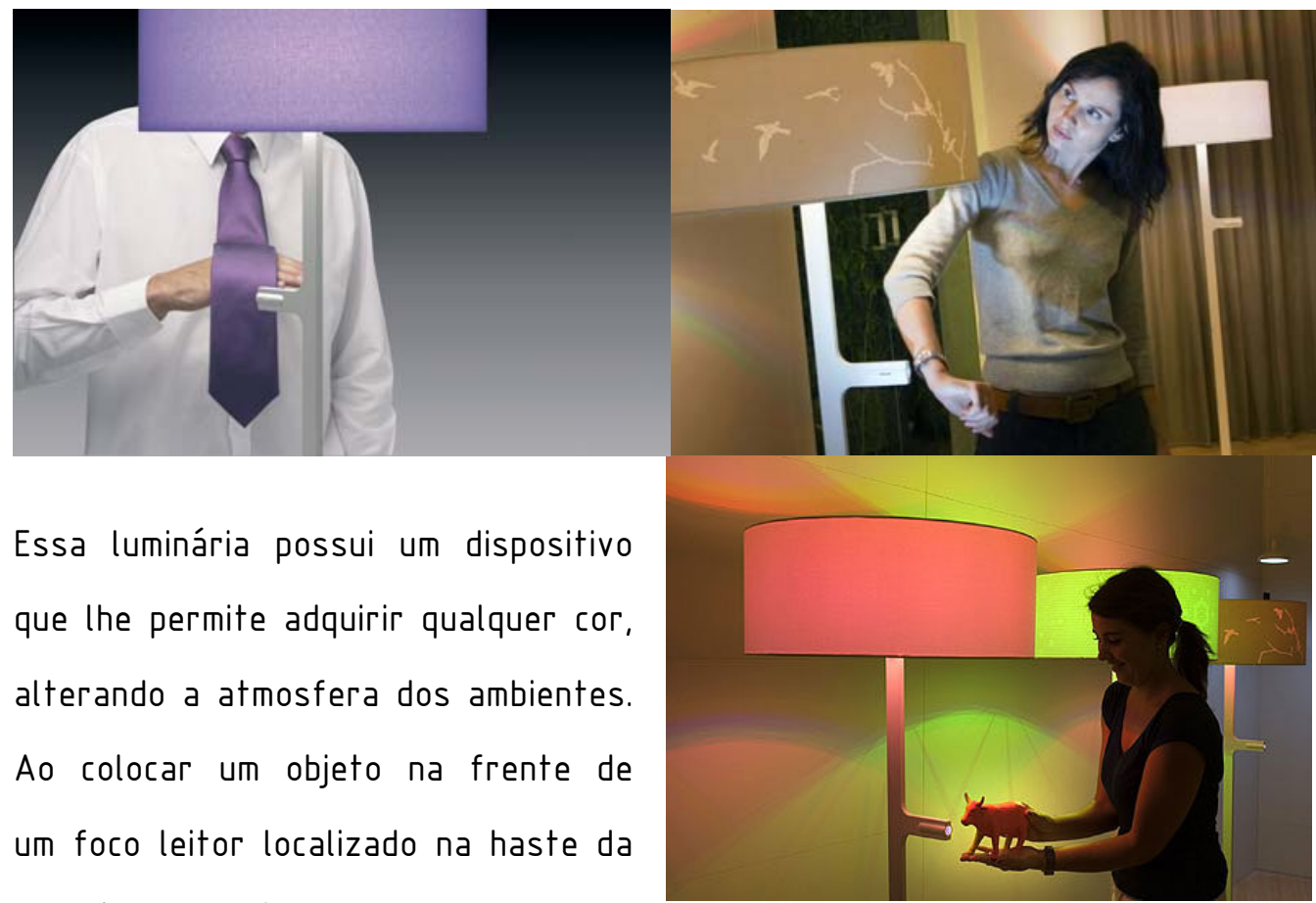

Essa luminária possui um dispositivo que the регmite adquirir qualquer сог, alterando a atmosfera dos ambientes. Ao colocar um objeto na frente de um foco leitor localizado na haste da luminária a lâmpada imediatamente adquiri a сог do objeto. Essa peça produz, assim, não apenas a uma interação com o indivíduo, como também induz a manipulação de objetos comuns que ocupam o espaço. Ressalta-se, o caráter duplo que a mediação assume nesse ргоcesso, de forma que tanto a luminária quanto esses objetos comuns †ornam-se capazes de рroduzir novas relações interativas com 0 indivíduo. Um outro fato importante acerca dessa luminária verifica-se pelo fato de que ao 
mimetizar a сог dos objetos ela está †ransferindo atributos dos mesmos рага uma outra escala espacial a partir da difusão da luz, criando ambiências агquitetônicas. De certo modo essa peça nos induz a pensar numa desautomatização do cotidiano, adensando as relações em torno de um ato соггіqueiro que vivenciamos ao acender e араgar a luz de forma que ele se constitua como experiência. A questão da escolha, da interação com objetos banais e da relação afetiva que se estabelece em †огno das alterações espaciais proporcionadas pela cor que adquire são aspectos importantes que регmeiam a dinamicidade dessa proposta de experiência. Numa postura mais convencional todo o ргоcesso poderia, рог exemplo, sег controlado рог meio de interfaces digitais nas quais se poderia escolher ou mesclar cores como осоггеm em ргоgramas gráficos de computador. Entretanto, ao ргорог que as cores sejam captadas diretamente de objetos concretos atribui-se uma outra dimensão de materialidade aos signos envolvidos neste processo, além de ргomover um ге-olhar рага objetos banais que a rotina instalada †огna sem importância em termos perceptivos. A manipulação de símbolos concretos assume grande importância frente a uma tendência contemporânea constatada pela Psicologia que resulta no fenômeno reconhecido como dessubstancialização do sujeito, como já exposto. Essa peça constitui também um exemplo em que a tecnologia digital é explorada de forma a ргoduzir matizes e potenciais analógicos. Ao indivíduo não cabe uma escolha dentre cores ргеdefinidas рог ргоgramas de algoritmos de informática, mas sim a reflexão 
асегса do espaço e dentre todas as cores existentes que ele pode assumir. 0 aspecto analógico envolvido neste processo é explorado também no âmbito da relação intra-objetos na medida em que se constroem vínculos por meio da associação da luminária a outros objetos pela cor. 
IT + Textiles [Fig. 48-55]

Interactive Institute

http://w3.tii.se/en/

Designers: Margot Jacobs, Hanna Landin, Peter Ljungstrand, Ramia Mazé, Johan Redström

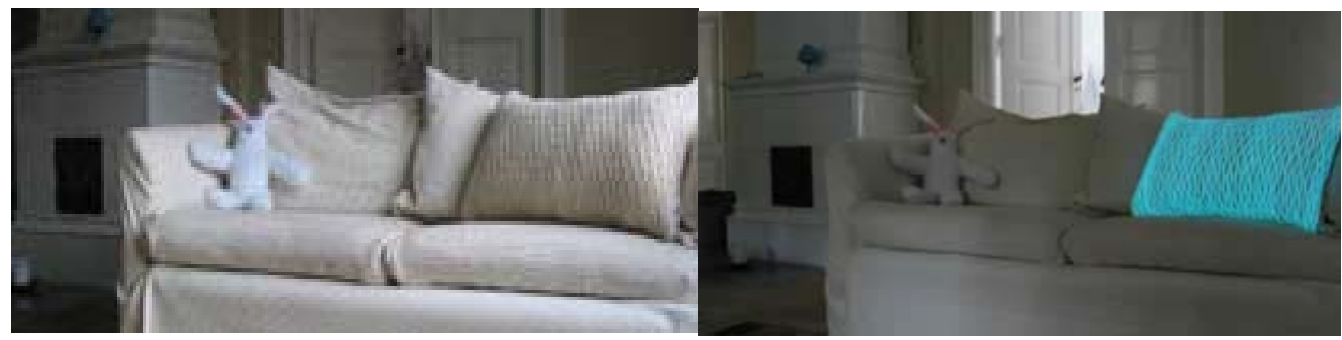

Esse projeto é composto рог um conjunto de †ravesseiros cujo tecido possui a capacidade luminosa. Sua luminescência é controlada рог contato físico que surge quando são tocados, abraçados, inclinados ou simplesmente агrumados na mobília рага se posicionem mais confortavelmente ao encosto ou descanso. Assim, o contado em um travesseiro localizado num determinado ambiente faz acender um outro localizado em outro ambiente ou em outra casa. A forma que o travesseiro irá acender é determinada a partir da intensidade e da freqüência do toque que está associada a padrões luminosos. A partir
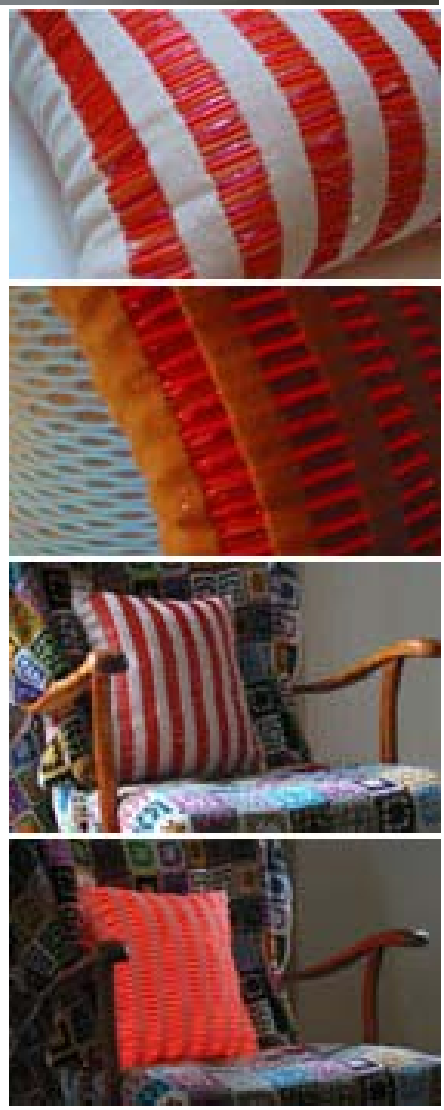
dessa propriedade os travesseiros oferecem um герегtório novo das possibilidades expressivas que consideram valores emocionais, sociais e estéticos e fornecem suporte рага uma outra forma de comunicação remota dentro do espaço doméstico, complementando as já existentes. No âmbito da interação entre individuo e objeto verifica-se num ргіmeiro momento uma осогrência apenas reativa, mas que posteriormente pode alcançar a uma atitude comportamental de envolvimento mais ргofundo. Ao estipular o toque como input рага a interação esse objeto explora a questão simbólica existente em †огno da proximidade entre as pessoas dando expressão aos sentimentos de saudade e de presença e criando uma relação de intimidade mediada pelos objetos. Cria também um sentimento de expectativa em relação a resposta luminosa e às suas possíveis interpretações. Essa associação entre toque e mensagem permite também que outros elementos secundários que compõem nossa comunicação cotidiana como os gestos sejam trocados também de forma remota, adicionando uma outra camada de experiência estética, afetiva e interpessoal em contextos do cotidiano. Essa mídia ressalta, assim, a atenção do indivíduo рага objetos convencionalmente tidos como banais tornando as atividades que se desenvolvem em †orno deles uma experiência mais densa e ligada também à contextos exteriores ao espaço que ocupa. Percebe-se a presença de signos digitais na construção de mensagens, compostos pelos padrões de freqüência e intensidade que a luz pode assumir. Entretanto, apesar de construídos digitalmente estes padrões estão abertos a diversas 
possibilidades de interpretação podendo ser associados a diversos tipos de estados emocionais ou atitudes comportamentais dos indivíduos. Essa abertura possibilita também que uma mesma resposta possa assumir significados diferentes a partir do contexto temporal ou que dá forma ao vínculo entre os interlocutores. 
The key table [Fig. 56-58]

Equator

http://www.equator.ac.uk/index.php/articles/632

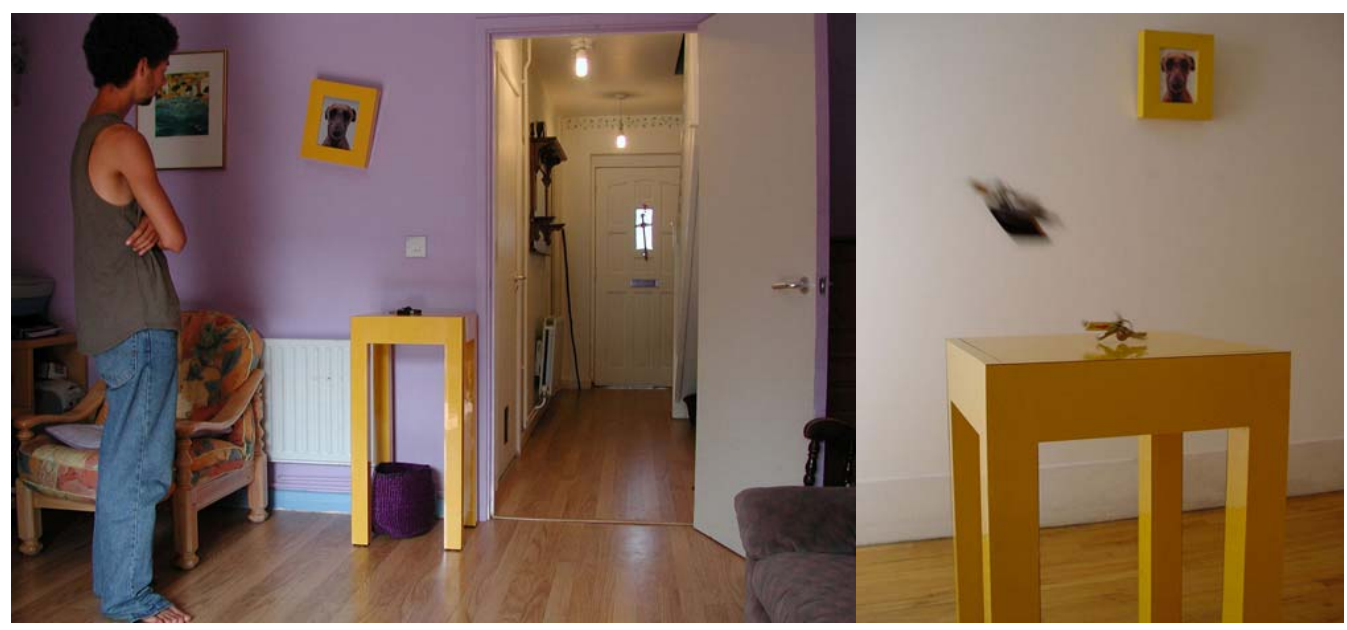

Essa proposta compõe-se por um conjunto que associa uma mesa para apoio de pequenos objetos a um quadro de рагеde, ambos feitos рага ocuparem lugares próximos aos acessos da casa. A localização da mesa próximo a entrada induz que pequenos objetos como chaves, carteiras sejam deixados sobre ela. Essa mesa vincula-se ao quadro na parede рог meio de um software que, de acordo com a força que os objetos são

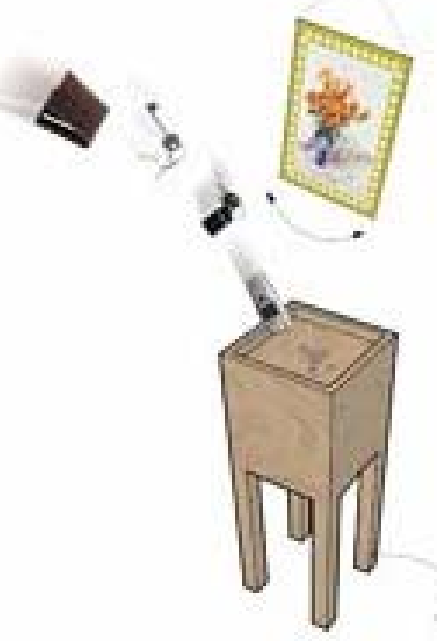


colocados sobre ela, faz o quadro inclinar-se gradualmente.

Essa mídia explora gestos banais do cotidiano de forma que eles se convertam em mensagem. Essas mensagens possibilitam interргеtações aceгca de aspectos ligados ao hábito e ao comportamento que cotidianamente passam desapercebidos pelas pessoas. Uma das interpretações possíveis verifica aspectos do humor a partir da intensidade com que os objetos são jogados sobre a mesa. Verifica-se a presença de uma interação reativa não apensa entre a mídia e o individuo como também entre a mesa e o quadro. Entretanto, ao colocar-se em contato com aspectos ocultos do seu comportamento o indivíduo pode ser levado a reposicionar-se frente seus hábitos dentro do espaço doméstico, fazendo surgir uma interação mútua. Esta mídia ressalta, assim, a atenção frente a gestos rotineiros que vivenciamos, atribuindo-lhes significados de forma a potencializar sua capacidade de gегаг experiências. 
The Hug T-Shirt [Fig. 59-63]

Cute Circuit

http://www.cutecircuit.com/now/projects/wearables/fr-hugs/

Designers: Francesca Rosella e Ryan Genz.
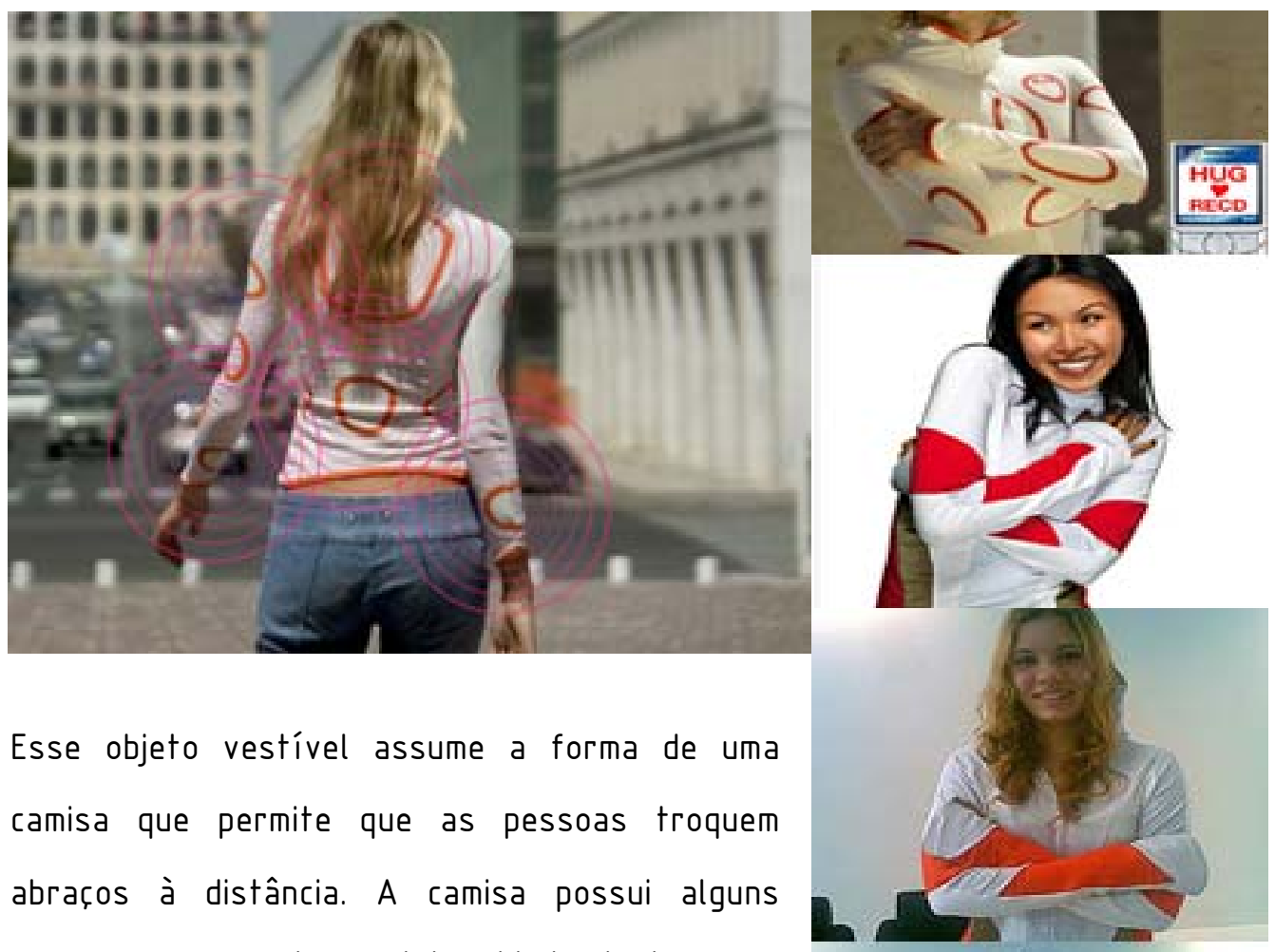

Esse objeto vestivel assume a forma de uma camisa que permite que as pessoas troquem abraços à distância. A camisa possui alguns sensores que captam a intensidade do toque, o calor da pele e o batimento cardíaco do remetente do abraço. A mensagem composta pelo cruzamento de todos os dados capturados produz em uma segunda pessoa a sensação de

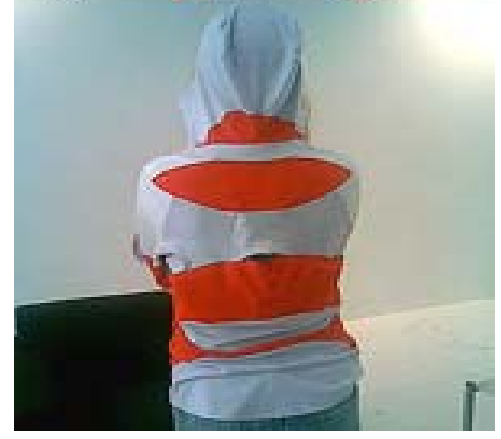


um abraço рог meio de atuadores inseridos na camisa. A transferência desses dados é feita com o apoio do celular. Assim, os dados capturados pelos sensores da camisa do emissor são transferidos рага seu celular via bluethoth. Esse celular †гаnsfere as informações рага o celular do гесерtor longínquo que рог sua vez são transferidos рага sua camisa, produzindo-lhe a sensação do abraço. As áreas vermelhas que demarcam a camisa sinaliza a posição dos sensores e atuadores que podem ser геtirados рага que a camisa possa ser lavada como uma outra qualquer. Estas regiões coloridas possuem a forma de pequenas almofadas móveis e também podem ser distribuídas em diversos pontos ao longo da camisa pelo próprio indivíduo que a usa. A idéia пão ргорõe a substituição do contato humano, mas permitir que ele aconteça redesenhado pela tecnologia, apenas nos casos em que se apresenta inviável pela distância.

A comunicação envolvida nesse processo elimina aspectos verbais e surge a partir da construção de comportamentos, explorando outros atributos do corpo e de seus gestos e movimentos. As mensagens possuem grande grau de interргеtação e podem assumir diversas significações de acordo com as características dos elementos inerentes aos próprios interlocutores de forma que um abraço entre pai e filho assuma significações diferentes daquele entre um casal de namorados ou dois amigos. Ргорõe uma interação mutua na medida em que não há uma hierarquia entre emissor e receptor de forma que qualquer 
pessoa é capaz de enviar e гесеber abraços por meio de um canal bidirecional de comunicação. A mediação proporcionada pela camisa envolve aspectos emocionais e afetivos. 0 objeto propõe, dessa forma, o redesenho da experiência em †огno do abraço e subverte seu significado. A sensação que emerge do gesto de trazer рга perto envolvido no abraço torna-se possível também à distância. Essa experiência constrói-se a partir da focalização e estimulação proporcionada pela mídia nas principais sensações envolvidas no abraço ressaltando a dimensão interativa e afetiva envolvida nesse gesto. 


\section{Tapete Mágico [Fig. 63-65]}

Nomads.usp

http://www.eesc.usp.br/nomads/

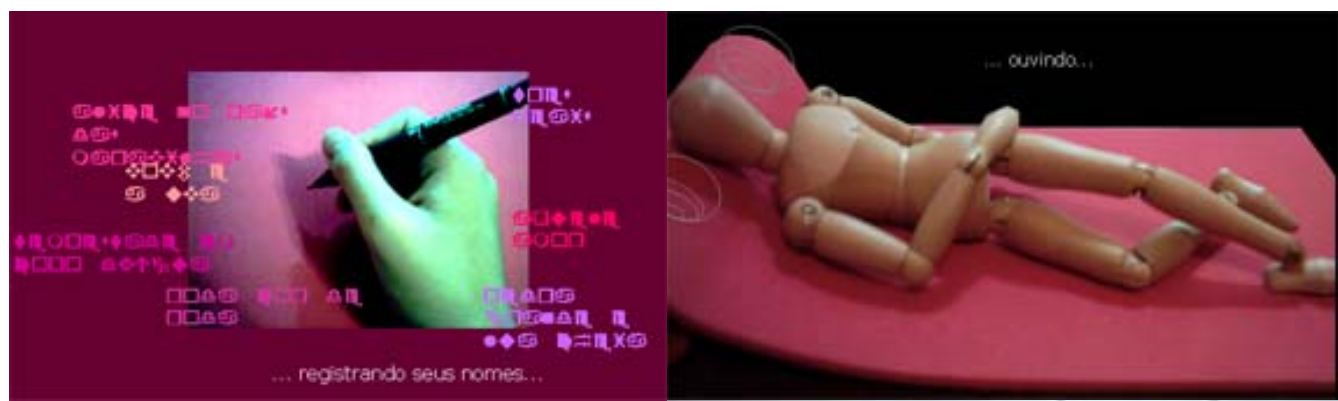

o Tapete mágico é um mobiliário de descanso com mídias integradas que possibilitam e estimulam a comunicação assíncrona entre as pessoas. Destaca-se nessa peça a utilização de tecnologia bastante simples рага sua formulação. Basicamente, o tapete conta com um sistema que permite gravar e tocar sons. É possível, assim, que uma pessoa deixe gravadas mensagens sonoras рага que possam ser ouvidas posteriormente рог outras pessoas. Além disso, o tapete conta com uma superfície na qual podem ser deixadas mensagens escritas рог canetas comuns. A peça proporciona assim a possibilidade de construção de mensagens 
escritas e sonoras estimulando a comunicação. A possibilidade de escrever sobre a peça faz com que ela transforme sua forma simbólica e concreta constantemente assumindo novos significados conforme vai sendo usada. Verifica-se também uma gradação no que se refere ao acesso de mensagens de forma que as mensagens escritas encontram-se mais expostas e acessíveis aos receptores que as sonoras. Esse aspecto permite ser explorado de forma que as mensagens escritas possam funcionar como instruções, especificando destinatários, e expondo dados que orientarão o acesso de mensagens que foram gravadas. A comunicação é explorada a partir de uma perspectiva que visa também materializar aspectos do processo comunicativo, trazendo a possibilidade de ргеservar registros sonoros e escritos e tornando a peça um arquivo de memórias comuns para um grupo de pessoas. A exploração da memória assume papel importantíssimo na potencializanção da construção de паггativas, possibilitando a assimilação de experiências. Аbrem-se possibilidades também рага o apoio à experiências de estudo e aprendizado que essa peça permite. A complementação desse mobiliário com tais ргоргiedades reforça seu papel como um lócus de estar, convivência e interação entre as pessoas. Promove assim, a comunicação tanto assíncrona рог meio da mídia como também síncrona e interpessoal reunindo pessoas em torno de um evento. 
Diolinda acqua [Fig. 66-67]

Nomads.usp

http://www.eesc.usp.br/nomads/

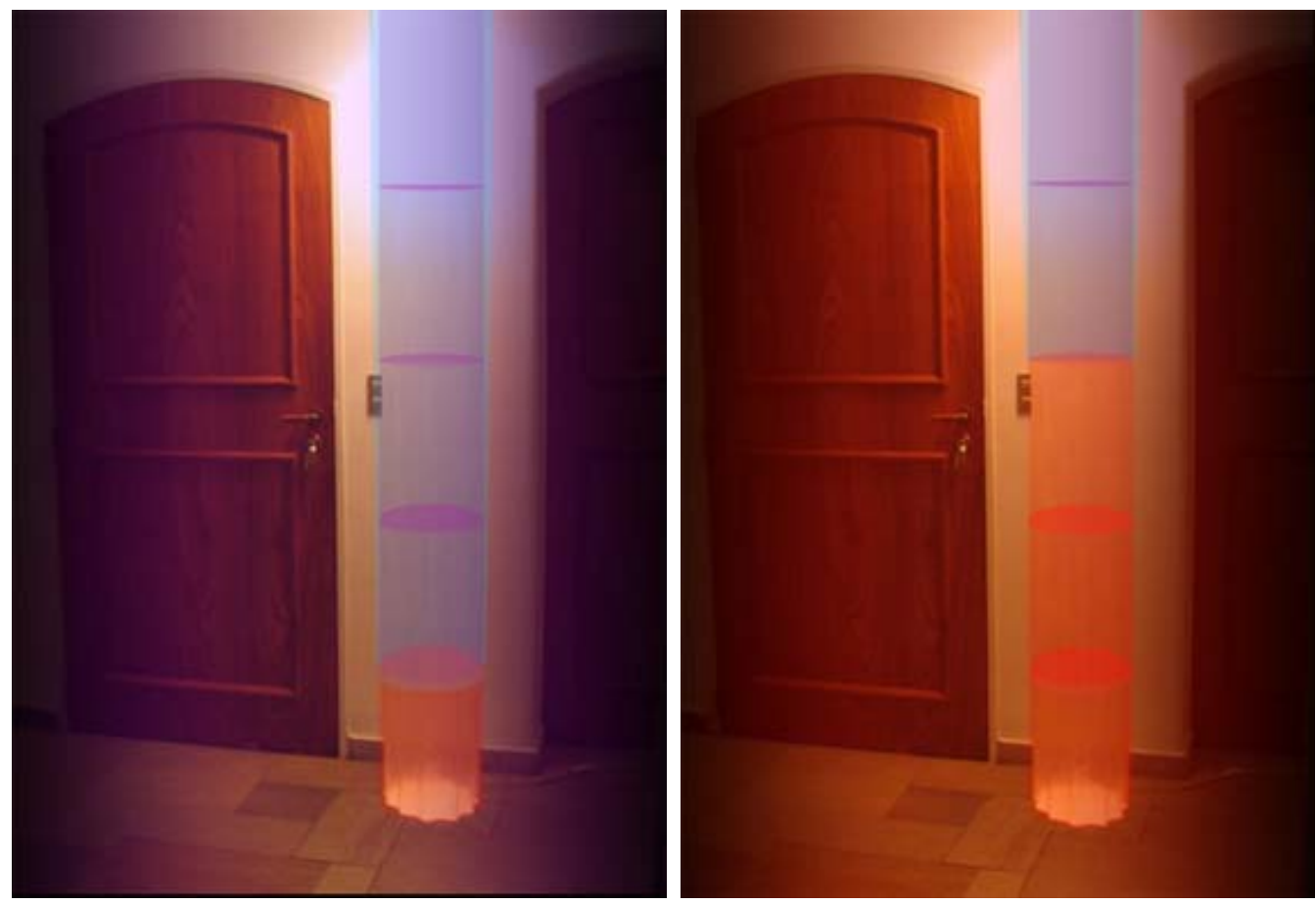

A Diolinda é uma luminária conectada a rede de abastecimento de água doméstico a partir de um programa que mede o consumo. A peça foi projetada рага оcupar um lugar visível como a entrada da habitação ou outro lugar com fluxo de passagem de forma que, ocasionalmente, possibilite que os indivíduos recebam mensagens sobre o nível de consumo de água de sua habitação. Assim, ao atingir determinadas faixas de consumo de água, a luminária assume 
uma cor específica, avisando os moradores da casa. No âmbito da comunicação ressalta-se a utilização de signos digitais que associam de maneira агbitraria faixas de consumo às cores, construindo códigos que podem ser compartilhados apenas рог um determinado grupo como é o caso da própria família. Este objeto traz à tona informações acerca de uma especificidade do cotidiano doméstico que, de um modo geral, nunca chegam aos indivíduos na forma de ргоcesso, mas sim de resultado. Ao expor aspectos ligados ao consumo de água de um determinado grupo, esse objeto visa ргomover uma reflexão em †orno dos hábitos ligados a uma atividade que tipicamente surge como simples vivência. Constrói uma rede simbólica que associa a luminária aos outros equipamentos hidráulicos de abastecimento da casa e aos gestos rotineiros e automatizados que estes induzem. Esta reflexão no âmbito do grupo pode resultar em аргеndizados, dando forma a experiências. Por outro lado, регcebe-se uma possibilidade bastante utilitária que esse objeto pode assumir no espaço doméstico, inclusive como forma de controlar o consumo, o que acabaria рог esmaecer a questão da experiência. 
Memo [Fig. 68-69]

Nomads.usp

http://www.eesc.usp.br/nomads/

0 Memo é um objeto composto por um compartimento de plástico transparente associado a um conjunto de leds que acendem em datas estipuladas e programáveis. A рroposta é que ele possa ser exposto na parede de ambientes habitacionais de maneira a facilitar sua visualização. 0 compartimento funciona como uma bolsa na qual pode ser inserido qualquer objeto de
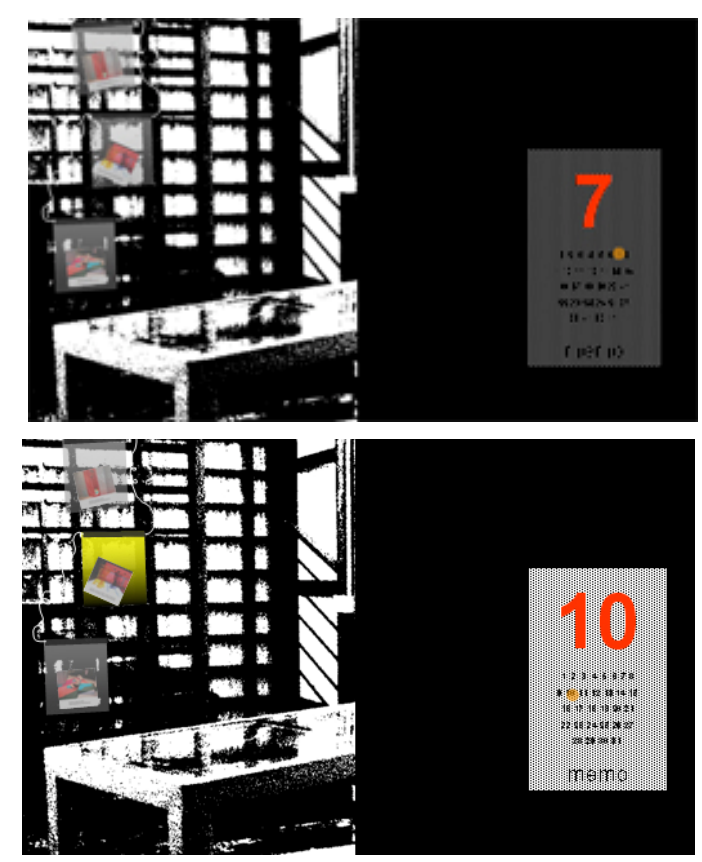
forma que quando os leds se acendem de acordo com a data programada, chamam a atenção do indivíduo para o objeto que ele guarda em seu interior. 0 objetivo da proposta é estimular a troca de mensagens entre membros de uma mesma família, fornecendo um apoio a realização da comunicação assíncrona intra-familiar. Ao propor que a realização de trocas de determinadas mensagens осогга em datas ргоgramadas ressalta-se a importância do aspecto temporal e contextual da comunicação. No seu funcionamento mais previsível o Memo permite, рог exemplo, que bilhetes 
escritos ou até mesmo contas a serem pagas sejam deixados no suporte transparente, sendo este рог sua vez ргоgramado рага асеnder em uma data estipulada pelo emissor na qual se deseja que a mensagem, na forma de lembrete, seja lida pelo геceptor. Entretanto, este objeto permite explorar a comunicação łambém de maneira menos utilitária na medida em que permite armazenar qualquer objeto em seu interior. Dentro da регspectiva que entende todo objeto constitui-se como signo emissor de mensagens, depreende-se possibilidades da exploração das ргоргiedades analógicas de um objeto na construção e troca de mensagens mais abertas de interргеtação. Um livro ou uma maçã deixados no compartimento †ransparente do Memo pode, assim, constituir mensagens analógicas que, associadas com um contexto temporal рог meio da programação que o dispositivo permite, produz comunicação. É interessante perceber a importância que este dispositivo proporciona ao aspecto contextual da comunicação. Dessa forma, um mesmo objeto pode surgir como mensagens de significados diferentes apenas variando o contexto temporal envolvido no processo. Além disso, ao permitir um alto grau de escolha do indivíduo, na medida em que permite que qualquer objeto seja colocado no suporte, o Memo explora a interação com outros objetos comuns que compõem o espaço doméstico e surge como um sistema na qual diversas experiências podem realizar-se de maneiras distintas. É importante регceber que pequenas sutilezas que compõem esse dispositivo permite envolver objetos concretos no ргоcesso de comunicação de maneira que estes assumam o papel 
de mensagens. Supondo-se, рог exemplo, que as mensagens aparecessem escritas imediatamente no Memo na data programada ao invés de chamar a atenção do гесерtor рага um objeto concreto, a exploração da mediação seria objetivada tendo um outro resultado, um fluxo mais rápido e com significados mais ргеcisos. Esta simples alteração, ареsar de valorizar a eficiência do processo, faria com que toda a questão simbólica envolvida ressaltasse a precisão dos significados em detrimento dos significantes (objetos), equalizando numa única matiz as especificidades do contexto analógico do processo comunicativo. Como visto essa tendência tecnológica que promove a total abstração do processo comunicativo revela um dos aspectos fenômeno verificado pela Sociologia como des-referencialização ou des-substancialização do sujeito.

Apesar da арагência imediatamente utilitária desse objeto, percebe-se, assim, que sua ргоposta principal não é †огпаг comunicação mais eficiente, mas sim estimulá-la e explorar novas formas que ela possa realizar-se, produzindo experiências assimiláveis. 


\subsection{Algumas relações possíveis}

Os exemplos de objetos analisados apresentam uma forte ligação com 0 cotidiano ou um potencial que thes регmite serem adaptados рага esse contexto. A exploração de conceitos como comunicação, mensagem, informação, mídia, mediação, interação e experiência apresentam-se em todos os exemplos selecionados. Entretanto em cada uma dessas propostas observam-se vertentes exploratórias que dão maior ênfase a algum desses conceitos, fazendo com que os demais surjam como uma instância que amplia esse ргіпеіго.

A mediação, entendida em sentido amplo, como já visto, está presente em qualquer relação que estabelecemos com outros elementos constitutivos do mundo e аргеsenta-se como a instância onde se constroem as conexões entre esses elementos. A interação, рог sua vez, resulta do formato e das especificidades que essas conexões assumem, possuindo a propriedade de dinamizar os processos que culminam na experiência, †ornando-as mais sólidas e passíveis de dar origem a narrativas pessoais.

Um ponto importante a ser salientado acerca da mediação ргoposta por alguns é que em certos casos há uma relação ambivalente. Isto осогге em ргоpostas como o Chameleon Lamp, o Memo, o Habitat, The key Table, The History Tablecloth em que, além da mediação que estas próprias mídias constroem, a 
interação dela resultante leva a manipulação também de outros objetos que compõem o espaço doméstico. Assim acontece com os objetos que são colocados sobre a mesa na proposta do Habitat, do The key Table e do The History Tablecloth, com os objetos coloridos dos quais a Chameleon Lamp copia a сог, e com aqueles que são postos dentro Memo. Esta postura resulta também na explогас̨ão do potencial que objetos banais e estáticos do cotidiano apresentam como emissores de mensagens, além de ргomover a revalorização dos mesmos ргopondo um re-olhar sobre o contexto que os envolve e que a rotina faz esmaecer. Ressalta-se também nessas propostas o estímulo à introdução de signos concretos no processo de comunicação, dinamizando-o com a inserção de instâncias materiais e imateriais.

Aspectos ligados ao co-envolvimento com as entidades projetadas lobjetos, parâmetros e relações) estipulam uma escala que vão da simples vivência à experiência. Assim, os elementos que tornam uma experiência mais densa аргеsentam-se diretamente vinculados à variedade e ao dinamismo das relações criadas. A interação assume um papel fundamental nesse processo que dinamiza estas relações, funcionando como um instrumento que permite movimentar eventos, variar seus padrões e alternar suas possibilidades. Ela encontra-se tanto em propostas que objetivam apenas construir um canal de atuação entre os interagentes como ргорõe o Brainball, evidenciando que, nesse caso, a interação é a principal relação projetada, como também em casos 
em que ela assume a forma de um elemento que amplia instâncias da comunicação, como осогге no Tapete Mágico, ou no Unfoldings. Nas propostas dos objetos IT + Textiles, The key Table, The History Tablecloth, Chameleon Lamp, Smoker's Lamp e Diolinda-acqua a interação que se constrói, num ргіmeiro momento, é tida como meramente reativa e, portanto, menos densa. Esse fato expõe uma possibilidade que pode levar à banalização da relação ргоjetada, fazendo com que ela se esmaeça e passe a surgir despercebida na rotina diária. Entretanto, é possível também que propostas desse tipo induzam a uma constante reorientação do comportamento, reforçando, assim, a interação ргojetada e fazendo surgir interações mais profundas com o objeto. No caso da Smoker's Lamp a proposta de uma revisão acerca dos hábitos mostra-se bastante evidente na reflexão que ela propõe a partir de uma interação reativa com a fumaça proveniente do gesto de fumar. Uma outra característica importante acerca desse grupo de objetos é a utilização de elementos do ргóprio cotidiano como input рага as interações. Gestos ligados a atividades que levam a um hábito de automatismo e que tradicionalmente surgem com pouca importância no dia-a-dia dão início a um processo de interação. É o caso de ações como acender ou apagar a luz (Chameleon Lamp), colocar um objeto sobre a mesa (Habitat, The key Table e The History Tablecloth,), аргіг а †огnеiгa (Diolinda), аггumar o †гаvesseiro na mobília рага o descanso (IT+Textiles). Esse aspecto leva a uma revalorização das atividades envolvidas em †orno desses gestos que compõem nosso comunicação e que 
quase sempre se constituem como vivência em detrimento da experiência. Vislumbra-se a partir daí, um ponto de exploração em propostas futuras: objetos que busquem ressaltar outros gestos e atividades simples como, рог exemplo, o consumo de energia elétrica ou gás, o uso da TV, аbгir o armário, plugar as tomadas, aguar as plantas, †госаг a água dos aquários, †гancar as fechaduras. Todos estes hábitos compõem nossa comunicação com espaços habitáveis e com as pessoas com quem compartilhamos esses espaços. Tais hábitos constituem uma instância da vida social que, tradicionalmente, encontra suportes rígidos e austeros no apoio de sua realização e culminam em a uma rotina que se instala pela repetição.

A associação de objetos a sentimentos por meio da simulação de presenças ou proximidades constitui um aspecto importante no trabalho de adensar as relações de envolvimento que levam às experiências. A formulação do Habitat propõe a construção de uma experiência de convivência à distância e explora de forma ргofunda aspectos emocionais e de intimidade. Os objetos The Hug TShirt, IT + Textiles e 6th sense pautam-se também na exploração dos sentimentos de ausência e presença рага formular suas proposições. No caso do The Hug T-Shirt a questão emocional apresenta-se fortemente explorada, dada a significação afeita que o gesto de abraço assume no imaginário das pessoas de um modo geral. Os objetos IT + Textiles ou o 6th sense, exploram os sentimentos de saudade e as sensações de proximidade que surgem a 
partir de uma mediação que promove uma associação simbólica entre estes objetos e alguém distante. Ressalta-se, assim, uma comunicação remota ргоduzida рог estas peças apoiada na utilização de uma convenção simbólica arbitrária e, portanto digital, рага a construção de mensagens, †ornando-as passíveis de leitura apenas para aqueles que conhecem essa convenção, tocando, desta forma, em aspectos de privacidade. Propostas como essas jogam com o universo que dá forma à linguagem na mediada em que, como já colocado, o signo аргesenta se como um rastro, uma ausência que se expressa pelo fato de que a coisa ou o conceito que гергеsenta não está verdadeiramente ргеsente nele. Entretanto, a sua interpretação semântica nos leva a uma ilusão que nos faz vê-lo como presença. Além disso, o signo induz a uma interргеtação que quando somada ao contexto temporal e de intimidade no âmbito dos interlocutores, estimula a imaginação e caba рог ampliar o limite dado pelo seu significado. Dessa forma, em propostas em que as mensagens são construídas a partir de recortes delimitados de imagens ou significados de um contexto remoto como são exemplos propostas como o Habitat, o 6th sense, o IT+textiles, abre-se uma possibilidade de intervenção do receptor рог meio de sua imaginação, ampliando, o contexto do qual provém a mensagem e os limites do recorte do cotidiano que ela carrega. A proposta do Wall of Remembrance joga com esses recortes, capturando fragmentos sonoros do cotidiano e permutando-os de forma a construir novas mensagem que acabam рог altегаг е ampliar а геalidade presente a partir de uma mesclagem com de 
pedaços de seu passado. Está mídia proporciona uma possibilidade bastante rica de intervenções pessoais na construção de narrativas e de experiências afetivas, com outras pessoas, explorando aspectos de suas histórias de convivência a partir da reordenação de seus fragmentos na forma de registros de som.

0 indivíduo, entendido como uma das entidades atuantes que compõe o sistema que leva à experiência, constitui uma reunião de atributos interativos, emocionais, e de forte relação afetiva com seus semelhantes, o que torna a comunicação interpessoal um campo exploratório potencial рага o fomento de experiências. Mobiliários como o Unfoldings e o Tapete Mágico, ao constituíremse como uma mídia também de relaxamento, surgem como um catalisador que aproxima as pessoas, tornando-as suscetíveis a uma experiência comunicativa. 0 tapete mágico abre uma possibilidade importante na troca de mensagens escritas e sonoras explorando a complementaridade e os níveis de acesso das mesmas por meio da mídia.

Verifica-se assim que, no âmbito do design para a experiência, estas peças аргеsentam gradações de envolvimento a partir da exploração dos elementos já аргеsentados, levando a propostas mais ou menos estimulantes da experiência. Entretanto, em todos os exemplos o objeto é tratado como um ponto em †огпо qual se parte рага desenhar relações, estimulando-lhes suas percepções e ampliando instâncias de sua vida social em diversos níveis. 


\section{CONSIDERAÇÕES FINAIS}



Se рог um lado a tecnologia é parte constitutiva de nosso cotidiano desde muito tempo, рог outro, o fato dela ainda ser constantemente reificada e vista como uma espécie de alienígena no contexto social revela a importância de explorações que busquem produzir uma complementaridade capaz de esmaecer uma falsa segregação que dá forma a binômios que colocam em pólos opostos: natural e artificial, original e simulado, concreto e virtual, analógico e digital, homem e máquina. Desconstruir a relação de oposição que vincula as entidades que compõem esses binômios não significa negar as diferenças que permeiam 0 universo de cada uma, mas explorá-las menos como separação e mais como junção a fim de ressaltar uma complementaridade que sem dúvida é presente. No âmbito do design рага a experiência entendemos que a chave para tal exploração parece residir muito mais no design da relação entre os objetos e entre estes e as pessoas do que propriamente no design de produtos tidos como entidades formais absolutas e concretas.

Esperamos que a discussão proposta por este trabalho possa contribuir não apenas рага o meio acadêmico, mas seja capaz também de ргomover uma reflexão no âmbito da produção de design apoiada no uso de tecnologias de informação e comunicação, a fim de romper com modelos enraizados de concepção. A leitura dos objetos realizada por este trabalho, bem como os critérios utilizados рага a mesma constituem apenas o inicio de um trabalho, cuja ampliação e aprofundamento surgem com suma importância no caminho de 
entender melhor as relações contemporâneas que o objeto tem adquirido quando se exploram as tecnologias de informação e comunicação. Uma das constatações da presente pesquisa é falta de trabalhos em língua portuguesa que discutam o design para a experiência, o que torna de suma importância pesquisas em âmbito nacional sobre esse tema. A análise dos produtos a partir apenas das informações disponibilizadas na internet constitui uma das limitações do trabalho e aponta uma continuidade possível para que em trabalhos futuros informações adquiridas diretamente рог meio do contato com designers e institutos de pesquisa possam ргoduzir uma análise mais profunda.

Depreendemos a partir de uma reflexão em †ordo do design рага experiência que, em alguns casos, considerar e entender aspectos que dão forma ao ргocesso, surge com maior relevância do que explicitar o produto ou 0 resultado alcançado. Dentro desse contexto e, numa posição quase metalingüística frente ao que se discute nesse trabalho, a nossa opinião é de que o grande resultado dessa pesquisa é a reflexão que ela propõe. Partindo deste principio, entendemos também que, em muitos casos, †гаzer a tona um problema ou formular perguntas produz contribuições muito mais relevantes do que apontar suas soluções ou respostas imediatas. Dessa forma, a questão deixada рог Wilton Azevedo no texto que introduz o capítulo 1 desse trabalho, apesar de bastante ampla, merece retorno não por cumprir a obrigação de construir uma resposta, mas рог considerar aspectos importantes no âmbito do 
design рага a experiência, das tecnologias de comunicação e informação e, sobretudo, рог questionar, rumo ao futuro, a pertinência da própria pergunta: 0 que é design?

"O que é design?

Talvez essa pergunta não tenha mais importância no futuro, pois para se manter vivo o homem vai ter que se apoderar do simulacro que ele criou. A importância dessa informação só vai ter sentido para cobrir os poucos espaços que sobraram.

Como disse Marcel Breuer "um dia quem sabe, nos sentaremos sobre cadeiras de ar sólido".

Se o design sempre questionou o espaço, pode ser que o homem em direção ao futuro comece a redesenhar o ar que nos resta para que possamos sentar, e quem sabe possamos ter o tempo desejado para a criação. Mas para o homem pós-moderno, antipresente e neofuturo a criação é um estalo, a linguagem é consumida diretamente na sua nascente e é espalhada pelo mundo em forma de propaganda.

Nesse ponto o design cultural adquire vários aspectos, e entre eles passa a ser a fonte geradora de uma antropologia que não está mais debaixo da terra.

Há um ditado taoísta que diz que o artista deve ser responsável pela influência que ele exerce. É através dessa influência que o design vem dialogando com o homem desde o principio de sua existência. Se não cabe mais a discussão do objeto utilitário, vale pensar o design em forma de redesign - a criação do objeto através dele mesmo.

Sempre se questionou o lado viciário da vida - a capacidade de simular a vivencia. $O$ Grande problema centrava-se em saber se estamos em contato com a vida ou se é apenas a reprodução da reprodução social através dos veículos de comunicação, mas uma coisa é certa: a lógica do futuro fez a linguagem pertencer a tudo, e basta estar vivo para que se tenha informação. 
Se ligamos a TV, lemos o mundo nos impressos, vemos out doors dos nossos carros, temos a impressão de que tudo que o homem adquiriu através da criação até hoje tem um rosto, o rosto da copia. O protótipo já é a linguagem da reprodução.

Cabe pensar que planejar o futuro é ter consciência do caos.

O design é sempre uma forma de planejar uma saída.” [AZEVEDO, 1998, p. 81-87] 
REFERÊNCIAS 



\section{Referências:}

AbBagnano, N. Dicionário de Filosofia. Editora Martins Fontes: São Paulo, 1999.

ACCIOLY, M. I. A Simulação na Era da Convergência Digital. Revista Razon y Palabra, no. 53. outubro/novembro de 2006. Disponível em: <http://www.razonypalabra.org.mx/ anteriores/n53/maccioly.html>. Acessado em: março de 2007.

Antoun, H. Para Acabar Com 0 Privilegio do Produto. Revista Estudos em Design: Rio de Janeiro, 1993. Disponível em: < http://www.eco.ufrj.br/antoun/textos/privilegio.pdf>

AZEVED0, W. 0 que é Design. Brasiliense: São Paulo, 1998.

BENJAMIN, W. Experiência e Pobreza. In: Magia e Técnica, Arte e Política: Ensaios sobre Literatura e Historia da Cultura, Оbras Escolhidas. Вrasiliense: São Paulo, 1987.

O Narrador. In: Magia e Técnica, Arte e Política: Ensaios sobre Literatura e Historia da Cultura, Obras Escolhidas. Вrasiliense: São Paulo, 1987.

BENNATON, J. 0 que é Cibernética. São Paulo: Editora Вrasiliense, 1984.

BERGSON, H. Matéria e memória. São Paulo: Martins Fontes, 199.

BERLO, D. K. 0 processo da comunicação: introdução à teoria e à prática. São Paulo: Martins Fontes, 1991. 
BLACKBURN, S. Dicionário Oxford de Filosofia. Jorge Zahar: Rio de Janeiro, 1997.

BLUMER, H. Symbolic Interacionism. Perspective and Method, Chicago: University of Chicago Рress, 1937.

BONIN, J. A. Delineamentos teórico-metodológicos para estudar a mediação do cotidiano na recepção. In: Ciberlegenda. n. 15. Rio de Janeiro, 2005. Disponível em: <http://www.uff.br/mestcii/jianni3.htm>. Acessado em: 27 de março de 2007.

BORDENAVE, J. E. D. 0 que é Comunicação. São Paulo: Вrasiliense, 2004.

BOURDIEU, Ріегге. La distinción: criterio y bases sociales del gusto. Madrid: Taurus Humanidades, 1991.

CAMARGO, L. 0 que é Lazer. São Paulo: Brasiliense, 1986.

CASTELLS, M. A sociedade em rede. SãoPaulo: Paz еТегга, 2000.

CERTEAU, M. A Invenção do Cotidiano: Artes de Fazer. Petrópolis: Vozes, 1996.

CORREIA, J. C. Elementos para uma Crítica da Mediação Moderna. 502NotFound, п. 54, 1998. Disponível em: < http://Www.bocc.ubi.pt/pag/соггеia-joaoelementos-critica-mediacao moderna.html> Acessado 27 de março de 2006.

CSIKSZENTMIHALYI, M. Flow: the psychology of optimal experience. New York: НагрегРегеппial, 1991.

DEBRAY, R. Vida e morte da imagem: uma historia do olhar no ocidente. Vozes: Petrópolis, 199 
DENIS, R. C. Uma Introdução à história do Design. São Paulo: Edgar Blücher, 2000.

DENIS, R. C. Uma Introdução à história do Design. São Paulo: Edgar Blücher, 2000.

DOMINGUES, J. A. Em Torno da Mediação e da constituição da Experiência. Revista Digital Recensio, 1999. Disponível em: < http://bocc.ubi.pt/pag/domingues-jose-antonio-mediacao.html> Acessado 03 de abril de 2005.

DUNKER, C. I. L. Fantasmas de Final de Ano. In: Revista Mente \& Cérebro. № 167. Dezembro de 2006. São Paulo: Editora Abril, 2006.

FISCHER, B. A. Interpersonal communication: pragmatics of human relationships. New York: Random House, 1987.

GIDDENS, A. Política, Sociologia e Teoria Social. São Paulo: UNESP, 1997

GIMORE, R. Alice no país do Quantum. Rio de Janeiro: Editora Jorge Zahar, 1998.

GONZÁLEZ, Jorge A. La telenovela en familia: una mirada en busca de horizonte. Estudios sobre las culturas contemporáneas, Colima, v.4, n.11, março de 1991.

GRAHAM, S. Bridging Urban Digital Divides? Urban Polarisation and Information and Communications Technologies. In: Urban Studies. Routledge: New York, 2002.

HARDTM, M.; NEGRI, A. Multidão: guerra e democracia na era do Império. Rio de Janeiro/São Paulo: Record, 2005. 
JAMESON, F. Pós-Modernismo. São Paulo: Editora Ática, 2004.

KANT, I. Critica da Razão Pura. São Paulo: Martin Claret, 2002.

KURZ, R. O complexo de Harry Potter. In: Jornal Folha de São Paulo, Caderno Mais!, p. 10. São Paulo: 30 de outubro de 2000.

LIMA. Trabalho imaterial, compartilhamento de informação e produção colaborativa na sociedade da informação. Disponivel em: <http://www.encontros-bibli.ufsc.br/Edicao_23/ lima.pdf>

LITTLEJONH, S. Fundamentos Teóricos da Comunicação. Rio de Janeiro: Zahar, 1982.

LUKÁCS, G. História e Consciência de Classe. São Paulo: Martins Fontes, 2003.

MACHADO, A. Máquina e imaginário. São Paulo: Edusp, 1993.

MANZINI, E., MERONI, A. Picnickit: riti alimentari nomadici. Apresentação de slides. Politécnico di Milano, Laboratorio di Disegno Industriale 1. Milão, 25 de maio de 2005.

MARX, K. A mercadoria. São Paulo: Ática, 2006.

MATOS, C. Conhecimento X Informação: Uma Discussão Necessária. Revista Espaço Acadêmico - № 31 - Dezembro de 2003. Disponível em: <http://wWw.espacoa cademico.com.br/031/31cmato.htm> Acessado em: outubro de 2006. 
MCLUHAN, M. Os meios de comunicação como extensão do homem. Cultrix: São Paulo, 1969

MOLLER, J. Mediação: Conceitos Fundamentais da Teologia. São Paulo: Martins Fontes, 1966.

MULDER, A. Understanding Media Theory. Roterdam: V2_Publishing/NAl Publishers, 2004.

MULDER, A. Understanding Media Theory. Roterdam: V2_Publishing/NAl Publishers, 2004.

PINE J., GILMORE J. The Experience Economy. São Paulo: Editora Campu, 199.

PRATSCHKE, A., TRAMONTANO, M., MOREIRA, E. Designer wanted! Interface usuário-computador, o design de um diálogo. In: Anais. Artigo apresentado ao IV Congresso Íbero Americano de Gráfica Digital: SIGRADI-2000. PROURB-UFRJ_ 25 a 28 de setembro de 2000.

PRIMO, A. Enfoques e Desfoques no estudo da interação mediada por computador. 404NotFound, ח. 45, 2005. Disponivel em: <http://wWw.facom.ufba.br/ciberpesquisa/ 404nOtFound/404_45.htm > Acessado em 04 de junho de 2006.

PRIMO, A. Interação Mútua e Interação Reativa: Uma Proposta de Estudo. 404NotFound, $\quad$ n. 45, 1998. Disponivel em:< http://wWw.psico.ufrgs.br/ aprimo/pb/intera.htm > Acessado em 31 de dezembro de 2005. 
PRoust, M. Em busca do Tempo Perdido: 0 Caminho de Swann. São Paulo:

Ediouro, 2002.

RABAÇA, C. A.; BARBOSA, G. G. Dicionário de Comunicação. Rio de Janeiro: Campus, 2001.

SANTOS, J. F. 0 que é Pós-moderno. São Paulo: Brasiliense, 2006.

SEGNINI, L. 0 que é Mercadoria. São Paulo: Вrasiliense, 1984.

SHANNON, C. e WEAVER, W. Teoria Matemática da Comunicação. São Paulo: Difel, 1977.

SHEDROFF, N. Experience Design 1. New Riders: Publishing, 2001.

SHIKATA, Y. The Final House. In: The Japan Architect: Framing of the House. Tóquio, 2000.

SHIKATA, Y. The Final House. In: The Japan Architect: Framing of the house. Tóquio, 2000.

SILVA, M. Sala de aula interativa. Rio de Janeiro: Quartet, 2000.

SLOTERDIJK, P. Regras para o parque humano: Uma resposta à carta de Heidegger sobre o Humanismo. Estação Liberdade: São Paulo, 2000.

STONE, A. R. Recordações da unidade Ou chegou a era da máquina e tudo o que eu ganhei foi esta horrível T-shirt in Revista de Comunicação e Linguagens, Real vs Virtual, org. José A. Вragança de MIRANDA. Lisboa: Edições Cosmos, 1999 (p.69-72). 
TARDE. G. Monadologia e sociologia. Petrópolis: VOZES, 2003.

tramontano, M. Novos Modos de Vida, Novos Espaços de Morar: Paris, São Paulo, Tokyo. Dissertação de doutorado. São Paulo: FAUUSP, 1998.

TRAMONTANO, M.; PRATSCHKE, A.; MARCHETTI, M. Um toque de Imaterialidade: 0 Impacto das Novas Mídias no Projeto do Espaço Doméstico. Apresentado no Seminário Internacional de Psicologia e Projeto do Ambiente Construído, Rio de Janeiго, 2000.

VYGOTSKY, L.S. A formação social da mente. São Paulo: Martins Fontes, 1988.

WATZLAWICK, P.; BEAVIN, J. H.; e JACKSON, D. D. Pragmática da comunicação humana. São Paulo: Cultrix, 1993.

WHITE, L. The Science of Culture. New York: Fаггаг, Straus, 1949

WIENER, N. Cibernética e Sociedade. 0 Uso Humano dos Seres Humanos. São Paulo: Cultrix, 1968.

WILLIAMS, Raymond. Television: technology and cultural form. Londres: Routledge, 1990.

YOLTON, J. W. Dicionario Locke. Rio de Janeiro: Jorge Zahar, 1996. 


\section{Lista de figuras:}

Fig. 1: Os Jetsons.

Fonte: http://www.hannabarbera.com.br/

Fig. 2-4: 0 cotidiano da família Jetsons.

Fonte: http://www.hannabarbera.com.br/

Fig. 5: Os Flintstones.

Fonte:http://www.hannabarbera.com.br/

Fig. 6-8: Os objetos cotidianos da família Flintstones

Fonte: http://www.hannabarbera.com.br/

Fig.9: Foto de diviuulgação do Ka-on

Fonte: http://dailysoy.blogspot.com/2004_09_01_archive.html

Fig. 10: Bancos ргоjetados рог Philippe Starck para o Parc de la Villette em Paris.

Fonte: http://www.villette.com/manif/manif.aspx?id=1022

Fig. 11: Banco Intitulado Come a Little Closer ргоjetado рог Nina Farkache. Fonte: http://www.droogdesign.nl/

Fig. 12: 22 Pop.

Fonte:http://ргоjectsfinal.interaction-ivrea.it/20032004/This\%20is\%20

Today\%202004/Communication\%20materials/

Fig. 13: Poltrona elástica Mies (1969).

Fonte: http://www.museum.vic.gov.au/design/exhibition/casablanca.asp 
Fig. 14: Assento Superonda (1966).

Fonte: http://www.museum.vic.gov.au/design/exhibition/casablanca.asp

Fig. 15: 0 anti-design do grupo Alchimia.

Fonte: http://www.museum.vic.gov.au/design/exhibition/casablanca.asp

Fig.16: Poltrona Di Proust promove uma sobreposição do tempo a ao contrapor a forma do objeto a suas cores expressionistas (1978).

Fonte: http://www.museum.vic.gov.au/design/exhibition/casablanca.asp

Fig. 16: A luminária projetada em 1987 рог Umeda (Memphis) ігоniza a forma dos objetos.

Fonte: http://www.museum.vic.gov.au/design/exhibition/casablanca.asp

Fig. 17: Mobiliário de descanso em forma de ringue.

Fonte: http://www.museum.vic.gov.au/design/exhibition/casablanca.asp

Fig. 18: Estante Carlton

Fonte: http://www.museum.vic.gov.au/design/exhibition/casablanca.asp

Fig. 19: Poltrona e otomana (1969).

Fonte: Fonte: http://www.museum.vic.gov.au/design/exhibition/casablanca.asp

Fig. 20: Oranienbaum Candy

Fonte: http://www.droogdesign.nl/

Fig. 21: Do Scratch

Fonte: http://www.droogdesign.nl/

Fig. 22-24: Habitat

Fonte: http://web.media.mit.edu/ stefan/hc/projects/habitat/ 
Fig. 25-26: Wall of remembrance

Fonte: http://smart.tii.se/smart/front_en.php

Fig. 27-32: Unfoldings

Fonte: http://smart.tii.se/smart/front_en.php

Fig. 33-36: The History Tablecloth

Fonte: http://www.equator.ac.uk/index.php/articles/632

Fig. 37-42: Smoker's La mp

Fonte: http://hehe.org.free.fr/hehe/smokinglamp/index.html

Fig. 43-44: 6th sense

Fonte: http://smart.tii.se/smart/projects/SixthSense/index_en.html

Fig. 45-46: Brainball [

Fonte: http://smart.tii.se/smart/projects/brainball/index_en.html

Fig. 47-49: Chameleon lamp

Fonte: http://www.design.philips.com/about/design/article-15002.page

Fig. 48-55: IT + Textiles

Fonte: http://w3.tii.se/en/ 
Fig. 56-58: The key table

Fonte: http://www.equator.ac.uk/index.php/articles/632

Fig. 59-63: The Hug T-Shirt

Fonte: http://www.cutecircuit.com/now/projects/wearables/fr-hugs/

Fig. 63-65: Tapete Edison

Fonte: Nomads.usp

Fig. 66-67: Diolinda acqua

Fonte: Nomads.usp

Fig. 68-69: Memo

Fonte: Nomads.usp 


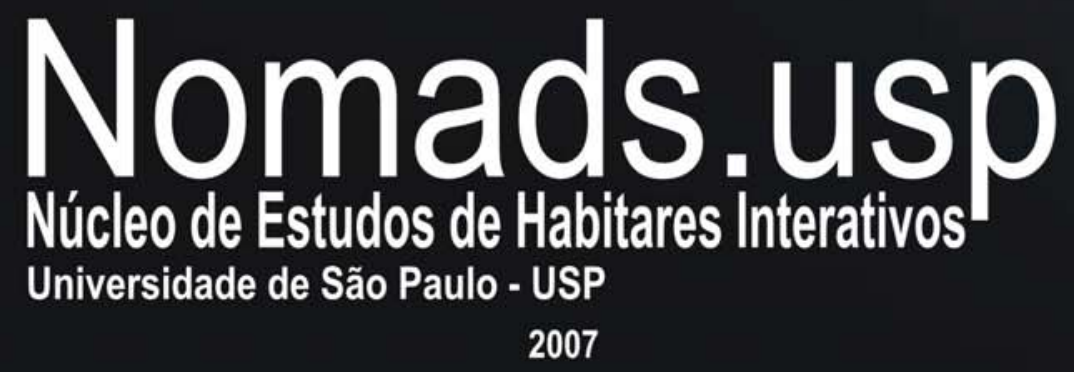

